Developing Terrestrial Trophic Models for Petroleum and Natural Gas Exploration and Production Sites: The Oklahoma Tallgrass Prairie Preserve Example

\author{
Authors \\ Michael Stevenson* \\ Jessie Coty* \\ Jeff Stewart* \\ Tina Carlsen* \\ Mac Callaham**
}

January 26, 2001

*Lawrence Livermore National Laboratory, Livermore, Calif.

**Oak Ridge National Laboratory, Oak Ridge, Tenn. 


\section{DISCLAIMER}

This document was prepared as an account of work sponsored by an agency of the United States Government. Neither the United States Government nor the University of California nor any of their employees, makes any warranty, express or implied, or assumes any legal liability or responsibility for the accuracy, completeness, or usefulness of any information, apparatus, product, or process disclosed, or represents that its use would not infringe privately owned rights. Reference herein to any specific commercial product, process, or service by trade name, trademark, manufacturer, or otherwise, does not necessarily constitute or imply its endorsement, recommendation, or favoring by the United States Government or the University of California. The views and opinions of authors expressed herein do not necessarily state or reflect those of the United States Government or the University of California, and shall not be used for advertising or product endorsement purposes.

This is a preprint of a paper intended for publication in a journal or proceedings. Since changes may be made before publication, this preprint is made available with the understanding that it will not be cited or reproduced without the permission of the author.

This report has been reproduced directly from the best available copy.

Available electronically at http://www.doc.gov/bridge

Available for a processing fee to U.S. Department of Energy

And its contractors in paper from

U.S. Department of Energy

Office of Scientific and Technical Information

P.O. Box 62

Oak Ridge, TN 37831-0062

Telephone: (865) 576-8401

Facsimile: (865) 576-5728

E-mail: reports@adonis.osti.gov

Available for the sale to the public from

U.S. Department of Commerce

National Technical Information Service

5285 Port Royal Road

Springfield, VA 22161

Telephone: (800) 553-6847

Facsimile: (703) 605-6900

E-mail: orders@ntis.fedworld.gov

Online ordering: http:/ / www.ntis.gov/ordering.htm

\section{OR}

Lawrence Livermore National Laboratory

Technical Information Department's Digital Library

http: / / www.llnl.gov/tid/Library.html 


\title{
Developing Terrestrial Trophic Models for Petroleum and Natural Gas Exploration and Production Sites: The Oklahoma Tallgrass Prairie Preserve Example
}

\author{
Authors \\ Michael Stevenson* \\ Jessie Coty* \\ Jeff Stewart* \\ Tina Carlsen* \\ Mac Callaham**
}

January 26, 2001

*Lawrence Livermore National Laboratory, Livermore, Calif.

**Oak Ridge National Laboratory, Oak Ridge, Tenn.

\section{Environmental Protection Department}





\section{Table of Contents}

Executive Summary SUMM-1

1. Introduction. 1

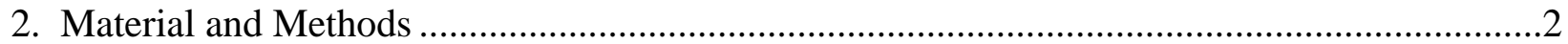

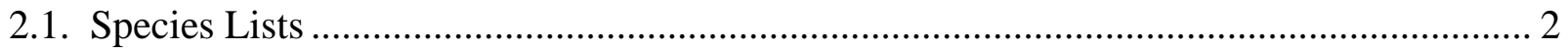

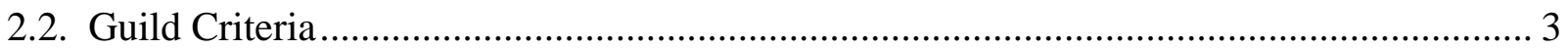

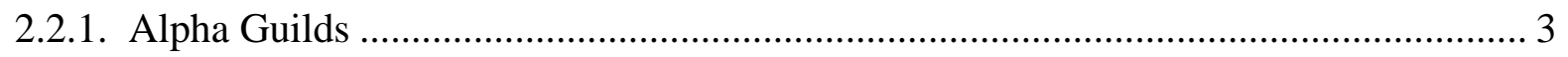

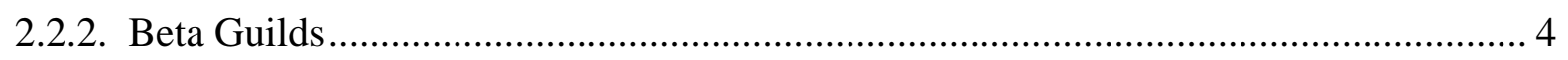

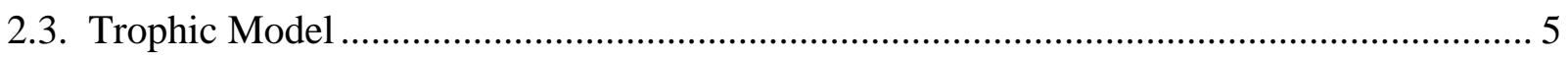

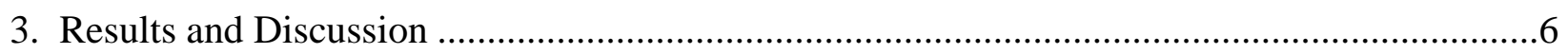

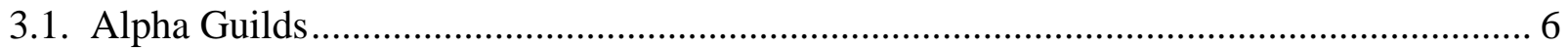

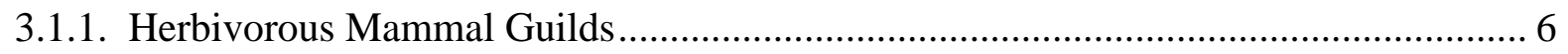

3.1.2. Omnivorous Mammal Guilds .............................................................................. 8

3.1.3. Carnivorous Mammal Guilds ……………......................................................... 9

3.1.4. Omnivorous Herptile Guild................................................................................. 10

3.1.5. Carnivorous Herptile Guilds ............................................................................... 10

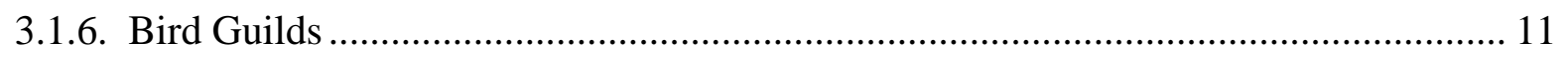

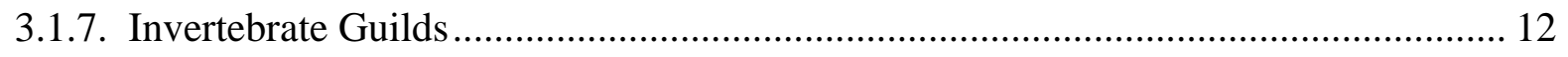

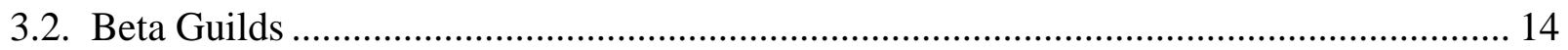

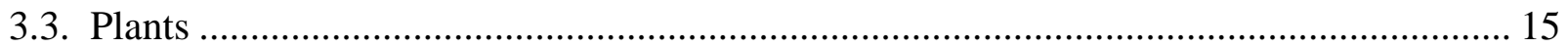

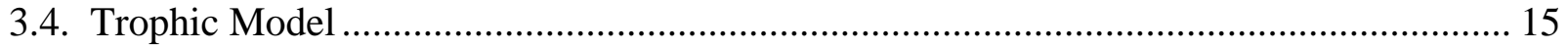

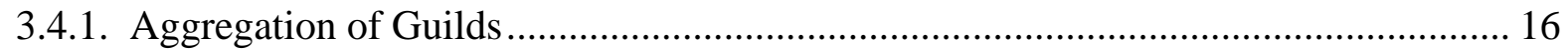

3.4.2. Considerations for the Selection of Endpoint Species ............................................... 17

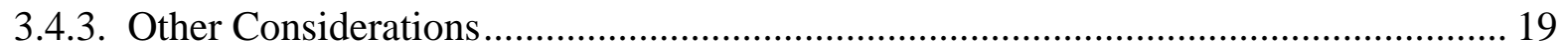

3.4.4. Expanding the Model: Combining Alpha and Beta Guilds........................................ 20

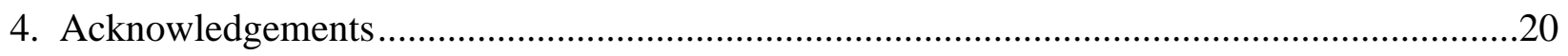

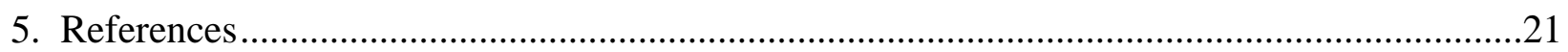

\section{List of Figures}

Figure 1. Source food webs at the Tallgrass Prairie Preserve, OK.

\section{List of Tables}

Table 1. Typical Plant Species of the Tallgrass Prairie Preserve, OK.......................................T-1

Table 2. Alpha Animal Guilds of the Tallgrass Prairie Preserve, OK .......................................T-4 
Table 3. Beta Animal Guilds of the Tallgrass Prairie Preserve, OK ..................................... T-12

Table 4. Dominant Plant Species at the Tallgrass Prairie Preserve, OK ................................T-25

Table 5. Food relationships between the various alpha guilds at the Tallgrass Prairie

Preserve, OK

Table 6. Metaguilds at the Tallgrass Prairie Preserve, OK

T-28

\section{Appendices}

Appendix A. Table A-1. Master Species List of the Tallgrass Prairie Preserve, Ok.

Appendix B. Table B-1. Partial list of animal species of the aquatic systems at the Tallgrass Prairie Preserve, OK

Appendix C. Areas of Further Research

C-1. Develop "Response Guilds"

C-2. Expand Species Information C-1

C-3. Include Temporal Variations C-2

C-4. Address Issues of Spatial Scale and Resolution

C-5. Utilize Statistical Techniques

C-6. Explicitly Examine Ecosystem Dynamics

C-7. References

Appendix D. References used for habitat preference of species at the Tallgrass

Prairie Preserve, OK

Appendix E Trophic Pathways at the Tallgrass Prairie Preserve, OK E-1

Appendix F Glossary .F-1 


\section{Executive Summary}

This document details procedures to be used when constructing a conceptual terrestrial trophic model for natural gas and oil exploration and production sites. A site conceptual trophic model is intended for use in evaluating ecological impacts of oil and brine releases at E\&P sites from a landscape or ecosystem perspective. The terrestrial trophic model protocol was developed using an example site, the Tallgrass Prairie Preserve (TPP) in Oklahoma. The procedure focuses on developing a terrestrial trophic model using information found in the primary literature, and augmented using site-specific research where available. Although the TPP has been the subject of considerable research and public interest since the high-profile reintroduction of bison (Bison bison) in 1993, little formal work has been done to develop a food web for the plant and animal communities found at the preserve. We describe how to divide species into guilds using explicit criteria on the basis of resource use and spatial distribution. For the TPP, sixteen guilds were developed for use in the trophic model, and the relationships among these guilds were analyzed. A brief discussion of the results of this model is provided, along with considerations for its use and areas for further study. 


\section{Introduction}

The United States petroleum and natural gas industry owns and operates large numbers of exploration and production (E\&P) sites. These are large sites (upwards of tens of thousands of acres) that are used for the exploration and production of natural gas and petroleum products. These sites typically contain intact expanses of natural habitat (such as grassland, forest or desert), in which exploration and production wells, distribution piping and tank batteries are installed and operated. Through the operation of such sites, releases of petroleum products and substances related to petroleum production (such as brine) periodically occur. Often, these releases only impact terrestrial resources, particularly in areas with limited numbers of wetlands or streams. The petroleum and natural gas industry is increasingly required to assess the ecological impacts of these releases. However, conducting an ecological risk assessment (ERA) focused only on the localized spill may provide a misleading and erroneous estimate of risk with respect to the entire E\&P site. Experience in conducting ERAs in other industries (such as hazardous waste sites) have shown these ERAs often consider areas that are too small to be ecologically relevant.

Therefore, Lawrence Livermore National Laboratory (LLNL), collaborating with Oak Ridge National Laboratory (ORNL), is engaged in a project to create tools and techniques for evaluating ecological impacts at E\&P sites from a larger landscape or ecosystem perspective. We have identified the creation of a site conceptual terrestrial trophic model as one of the first steps in evaluating a site from a landscape perspective. In this document, we outline the steps necessary to create such a trophic model. This is done through evaluating an example site, the Tallgrass Prairie Preserve (TPP) in northeastern Oklahoma. We have focused on creating a terrestrial trophic model using information from the primary literature and relevant research being currently conducted at the TPP. While other E\&P sites may not have such extensive research activity, creation of a trophic model should still be possible using information found in the open literature on the types of habitats found at the site, regardless of whether the specific site has been studied. By following the steps outlined here, a conceptual terrestrial trophic model suitable for use in estimating the impacts from the operation of E\&P sites should be possible.

The Tallgrass Prairie Preserve (TPP) consists of 15,200 hectares (ha) of rolling prairie in northeastern Oklahoma owned by the Nature Conservancy (ONHI, 1993; Hamilton, 1996). It plays host to a wide variety of plant and animal species (many of which are prairie-dependent), and represents one of the last substantial remnants of the tallgrass prairie ecosystem, which historically covered 5.7 million ha of the United States and Canada (Madson, 1990). The TPP became home again to bison when they were reintroduced in 1993. Since that time, the Nature Conservancy has used fire and bison grazing as primary management practices to achieve prairie restoration, reenacting the natural disturbances that historically functioned to maintain the ecosystem (Hamilton, 1996).

The TPP is also an E\&P site, with over 600 historic wells, and 120 active wells in the preserve. Oil and brine spills have recently occurred in the preserve. The site contains five historic brine scars, several recent spills of brine, oil, or oil and brine (within the past 2 years), along with older spill sites ( 8 to 15 years). Thus, the TPP is ideally suited for use as an example site in creating tools and techniques to evaluate E\&P sites from a landscape or ecosystem 
perspective. In particular, the TPP will be useful in evaluating the effect of size and spatial distribution of terrestrial releases on community and ecosystem structure or function as a result of habitat destruction or degradation.

In this paper we evaluate the trophic system at the TPP, and develop a conceptual terrestrial trophic model for the preserve. In doing so, we develop a methodology for analyzing terrestrial trophic systems that may be used at other E\&P sites. Here we describe the process of dividing species into guilds using several methods. These guilds are then used as building blocks to construct a model that represents the relationships among the terrestrial biota at a site. Such a trophic model can then be used to select representative species from each guild ("endpoint species") as indicators for the integrity of community structure and function of a site. The endpoint species are usually selected using four criteria (adapted from Suter, 1993): (1) social relevance, (2) biological relevance, (3) predictability and measurability, and (4) sensitivity to disturbance. The terrestrial trophic model was therefore developed with these four criteria in mind.

\section{Material and Methods}

There are three basic steps in the construction of a conceptual terrestrial trophic model. These are (1) creating a list of species expected to occur at the site, (2) assigning the species to guilds, and (3) constructing the trophic model through an analysis of the relationships between guilds. A conceptual terrestrial trophic model constructed for use in evaluating E\&P sites is not intended to be an exhaustive model of all types of species found at the site. Rather, it focuses on the creation of guilds and foodwebs of those groups most likely to used in additional evaluations.

\subsection{Species Lists}

Prior to the construction of a species list, it is necessary to know the types of habitats found at the site. If site-specific data is not available, general habitat descriptions for most areas of the United States can be found in the open literature. A site visit by a knowledgeable biologist or ecologist may also be required. State natural heritage and fish and wildlife agencies may also have useful data. Once the habitats are defined, species data can be gathered from a variety of sources. For the TPP, these included a 1993 report published by the Oklahoma Biological Survey (ONHI, 1993), species lists obtained from the Nature Conservancy (Nature Conservancy, 1996) and Oklahoma State University (Palmer, unpublished data), as well as a survey of the open literature. Species found in similar ecosystems, such as the Konza Prairie Long-Term Environmental Research Site (LTER), were not included, although data regarding diet and habitat preferences in some cases were used. Although it was not necessary for us to use species data from similar ecosystems for the TPP, these types of data should be used at E\&P sites that have not been as well studied as the TPP.

A master list of animal species found at the TPP is included in Appendix A. Time constraints and the focus of the study precluded a comprehensive analysis of plants and fungi, and invertebrates also received a limited treatment; these compartments may be expanded in the future if the need arises. As this study focuses on the terrestrial ecosystem, species strictly related to the aquatic systems at the TPP are also omitted, although a partial list of these species is 
provided for reference (Appendix B). The sources for all information regarding each species is noted, except in the case of very general information or "common knowledge" (e.g., the designation of hawks as raptors).

\subsection{Guild Criteria}

Many different methods exist to define guilds. Wilson (1999) made a basic distinction between two types of guilds: alpha and beta. An alpha guild is based on resource use: guild members use the same class of resources in a similar way. This is what Root (1967) originally envisioned when he first introduced the concept of the guild, and these guilds are therefore commonly referred to as "Rootian" guilds. A beta guild, in contrast, bases classifications on environmental conditions: guild members share similar space along multiple environmental gradients (i.e., occupy the same or a similar niche). The two types of guilds therefore fundamentally diverge in character, as alpha guild members tend to be competitors, and hence are not expected to coexist, whereas beta guild members are found together occupying similar habitats. The distinction between the two types of guilds is useful; however, it remains theoretical. In practice, some crossover exists between these two concepts. For instance, environmental conditions, depending upon the context, can be construed as resources (e.g., habitat).

The literature review performed for this research indicated two key problems commonly associated with efforts to delineate guilds. First, we found that the criteria used to assign species to guilds are either poorly defined, arbitrary, or not provided at all. "Lack of stated, unambiguous criteria for these (guild) assignments can potentially lead to ambiguous results and controversial interpretations" (Simberloff and Dayan, 1991). Second, guild definitions, as theoretical constructs, often are not developed such that they are useful for further analysis.

To avoid these problems, the criteria used for guild assignment in the present analysis have been clearly and explicitly defined, with consideration given to their eventual use in both generating the conceptual trophic model and determining the results of disturbances throughout the TPP system. Guild definition descriptions follow Wilson (1999), as his is the most comprehensive review to date. Both alpha and beta guilds were constructed to increase the depth of analysis.

\subsubsection{Alpha Guilds}

In delineating the alpha guilds, we refer back to the classic definition of a guild: "...a group of species that exploit the same class of environmental resources in a similar way" (Root, 1967). Because we intend to develop a food web using these guilds, we considered food as the primary environmental resource. To partition this resource into classes, and to ensure that each guild is internally consistent in terms of method of exploitation, we used two criteria to delineate the alpha animal guilds:

- Type of Food Consumed. We divided species into three general categories: carnivore, herbivore, and omnivore. In some cases, subdivisions were made among these categories to allow higher resolution (e.g., dividing carnivores by the type of prey), although the guild categories as constructed do not define the life-stage or physical part of the food resource used (e.g., birds vs. eggs; folivores vs. granivores). Guild designations are based 
on primary food consumption; incidental ingestion, unless it constitutes a significant portion of the diet, was not considered as relevant. Omnivory is used to describe species that feed upon both primary and secondary producers.

- Taxonomy. The categories obtained from (1) are then further divided either by taxonomy, as mammals (Mammalia), herptiles (Amphibia and Reptilia), birds (Aves), or invertebrates (all non-chordates). In some cases, further subdivisions are made on the basis of body size or method of food consumption, given its effect on either specific consumption patterns or use by predators.

Following Wilson (1999), these criteria form an "objective character Rootian guild," based on measurable attributes of the species. Criterion (1) is commonly found in many studies which assign species to guilds; however, criterion (2) is more unusual, as the classic "guild" ignores taxonomic boundaries, and guild members in many studies typically span a variety of taxa. We selected this second criterion for several reasons. First, animals with similar taxonomy tend to use resources in similar ways (MacNally and Doolan, 1986); therefore, the criterion could be potentially used as a proxy for specific foraging habit. For instance, by hunting from the air, raptors capture prey in quite a different way than do carnivorous mammals. Similarly, bison (Bison bison) and cattle (Bos spp.) share similar taxonomy and similar foraging habits. In contrast, the quantity of herbage consumed by an individual bison is orders of magnitude larger than that consumed by an individual deer mouse (Peromyscus maniculatus) (although deer mice may collectively consume more than bison). Second, closely related species often overlap in other ways besides foraging habit (Simberloff and Dayan, 1991); these overlaps can include habitat preference, home range size, role in ecosystem function, and more important, response to disturbance. In theory, events that affect the chosen class of environmental resource (food) will similarly affect all the members of the guild using that resource, although this may not be the case, when there is considerable diversity within a guild (see Section 3.4.3, Considerations, below). Third, as a convention, food webs are typically divided along taxonomic boundaries (DeAngelis, 1992). Whether this is an appropriate method for developing food webs, or simply an artifact stemming from habit or researchers' biases, is subject to debate. It should be noted that, as part of the analysis of the trophic structure at the preserve, several of the guild categories developed in this report are also aggregated into "metaguilds," which more closely follow the classic Rootian guilds that ignore taxonomic boundaries. Taxonomy remains only an approximate tool for delineating similarities between species.

The resulting guilds take the form of Schoener's (1986) "taxon-guilds," which he defines as groups of closely related species using the same resource.

\subsubsection{Beta Guilds}

For this study, habitat type is considered the primary criterion for dividing species into beta guilds. As defined by Oklahoma Natural Heritage Inventory (1993) and Payne and Caire (1999), six distinct terrestrial habitats are found at the TPP: prairie, upland deciduous forest, deciduous riparian forest, grassy riparian, disturbed areas, and rocky outcrops. Percentage areas for upland deciduous forest, deciduous riparian forest, deciduous riparian forest, grassy riparian, and disturbed areas were estimated using an area-line meter (Planix 5000) on topographic maps (Payne and Caire, 1999). As rock outcrop areas are not demarcated on these maps, they were estimated conservatively to be one-half of the amount of disturbed area. Percentage area of 
prairie habitat was then obtained by subtracting these areas from the total area of the Preserve. Typical plant species for each habitat are given in Table 1.

- Prairie. These are classic open, rolling fields, covering $92.3 \%$ of the area of the preserve.

- Upland deciduous forest. This occurs at the top of many of the larger hills, and covers $4 \%$ of the preserve.

- Deciduous Riparian Forest. This habitat occurs adjacent to lowland creeks (e.g., Sand Creek, Wild Hog Creek, and Bird Creek), and constitutes approximately $2.5 \%$ of the area of the preserve.

- Grassy Riparian. This habitat borders spring-fed streams that meander through the prairie en route to the major creeks mentioned above, and constitutes $0.6 \%$ of the area of the preserve.

- Disturbed areas. These are habitats currently experiencing anthropogenic disturbance, consisting mainly of human-built structures, such as buildings, oil-production sites, corrals, or roads, and cover $0.4 \%$ of the preserve.

- Rocky outcrops. These are found on the edges of hills and in areas of extensive erosion, and cover $0.2 \%$ of the preserve area.

With these categories, we divided species into guilds utilizing observed data (in the case of most species of mammals) as well as deductions using general habitat preference (herptiles, invertebrates, birds, and some mammals). Therefore, these definitions are a mixture of the fundamental niches and realized niches for these species. As a result, they should be used as general guidelines for species occurrence rather than true indicators of actual location. In particular, the temporal (e.g., seasonal) variations in the location of species have not been examined, in part due to a lack of data (see discussion in Appendix C). The beta guilds correspond with Wilson's (1999) "spatial distribution (beta) guilds." See Appendix D for a list of sources of habitat data.

\subsection{Trophic Model}

Typically, trophic species are used as basic units for development of a trophic model. A trophic species is a set of organisms with identical predator and prey species (Schoener, 1989; Pimm et al., 1991). However, because the intent of this study relates to impact assessment, trophic species were abandoned in favor of alpha guilds. While the alpha guilds approximate trophic species, the level of species aggregation is higher in most of the alpha guilds in this study. As mentioned earlier, aggregation based on taxonomy, body size, etc., may assist with understanding other common aspects of guild members besides foraging, potentially including response to disturbance.

Relationships between the guilds were determined based on dietary information collected in the creation of the alpha guilds. Each guild was given the binary designation of prey/not prey relative to each of the other guilds in the study. The resulting connections form a "cumulative" web (with observations aggregated over time, in contrast with a time-specific web; Pimm et al., 1991). Statistical analyses were then performed on the web to increase understanding and compare it against other published food webs. These were completed in the following manner 
(definitions mostly follow Pimm et al., 1991): (1) for the purposes of our analysis, guilds were treated as trophic species (S); (2) a "link" (L) is a predator/prey interaction; (3) the number of possible links was $\mathrm{S}^{2}$ (i.e., the maximum number of possible predator/prey interactions; "looping," or feeding on members of one's own guild, was allowed); (4) connectance (C) was determined by dividing the number of realized links by the number of possible links $\left(\mathrm{L} / \mathrm{S}^{2}\right)$; and (5) the linkage density was defined as the average number of links per guild (L/S).

\section{Results and Discussion}

\subsection{Alpha Guilds}

Sixteen distinct alpha animal guilds are found at the TPP (Table 2). Because many of the species sharing guilds coexist, competitive exclusion does not seem to be present among the alpha guilds, at least at the large spatial scale of the preserve. This is not surprising, because guild members are expected to coexist when the type, size, or location of prey is different, or when the method of capturing prey varies within a guild (Risser et al., 1981). However, some evidence indicates that competitive exclusion may occur between several of the species with similar food habits. For instance, in the Konza Prairie LTER, Kaufman et al. (1998) found an inverse relationship between bison grazing on the one hand, and prairie vole and harvest mouse populations on the other hand. These three species are all part of the herbivorous mammal guilds (see below). This evidence may support the alpha guild structure, because it can be posited that such a relationship arises from competition; however, more study would be necessary to assert competitive exclusion within the guilds. Given the limited spatial distribution data and the short time period from which species information was drawn, other occurrences of competitive exclusion may not be evident.

The following is a brief description of the species found in each guild, their dietary habits, and common predators. These guilds should be taken as general guidelines for feeding habits, as feeding may occur outside these categories, particularly at times of stress or food scarcity.

\subsubsection{Herbivorous Mammal Guilds}

The herbivorous mammals are divided into three separate guilds because of clear differences in body size and feeding habits, which in turn affect quantity of vegetation consumed per animal, and the set of predators who prey upon these herbivores.

\subsubsection{Herbivorous Mammal Guild 1a-Large Grazers}

Two species make up this guild, the bison (Bison bison) and the cow (Bos spp.). The Nature Conservancy, as part of the management of the preserve, regulates the populations of both species (Hamilton, 1996). Bison eat primarily grasses and sedges, consisting of up to 99 percent of their diet by weight (Van Vuren, 1984; Coppedge and Shaw, 1998), and show a preference for vegetation in areas that have been burned in the last year (Knapp et al., 1999). Species consumed are primarily grasses in the bluestem complex (Andropogen spp., Paspalum spp., Sorghastrum spp., and Sorghum spp.), Sporobolus spp., and Carex spp. (Coppedge and Shaw, 1998). Comparative fecal analysis of cattle and bison show high dietary overlap, although cattle exhibit 
wider dietary niche breadth, consuming a more variable set of species that generally includes a larger proportion of forbs and shrubs (Van Vuren and Bray, 1983; Van Vuren, 1984; Damhoureyeh and Hartnett, 1997). One study (Damhoureyeh and Hartnett, 1997) found differing impacts between bison and cattle in the composition of tallgrass plant communities; in particular, forb response was complex and varied significantly between plant species, fire regimes, and plant life history stage. Bison and cattle may also influence plant communities through other disturbances associated with non-grazing activities (e.g., trampling and excretion) (Damhoureyeh and Hartnett, 1997).

Predators of this guild include the coyote (Canis latrans) and mountain lion (Felis concolor), although predation may be limited to juveniles and carrion (Chapman and Feldhamer, 1982; Lindzey, 1987).

\subsubsection{Herbivorous Mammal Guild 1b-Browsers}

This guild consists of one species, the white-tailed deer (Odocoileus virginianus). The deer differs significantly from the previous set of herbivores in several ways. First, humans do not directly regulate its population in the TPP. Second, it is a browser rather than a grazer, and selects distinctly different plant species as food. Vegetation consumed varies with season and availability, but generally consists of forbs, browse, and smaller amounts of grasses and trees/shrubs (Bryant et al., 1996; Myers et al., 2000). In the cross-timbers region in Oklahoma (possessing similar vegetation to the TPP), Bryant et al. (1996) found a subset of seven species preferred by white-tailed deer: acorns (Quercus spp.), Osage orange (Maclura pomifera), Carolina snailseed (Cocculus carolinus), three-seeded mercury (Acalypha spp.), ticklover (Desmodium spp.), and brome (Bromus spp.).

The deer is preyed upon by large omnivorous and carnivorous mammals such as bobcat (Felis rufus), coyote (Canis latrans) and mountain lion (Felis concolor), and to a lesser extent, the gray fox (Urocyon cinereoargenteus) (Mech, 1984; Greenberg and Pelton, 1991; Brillhart and Kaufman, 1994; Myers et al., 2000).

\subsubsection{Herbivorous Mammal Guild 2-Smaller Herbivores}

Species in this guild include the beaver (Castor canadensis) and various species of lagomorph, rodent, and vole. Most species are generalist herbivores, feeding on a diversity of plant material. For instance, the eastern cottontail (Sylvilagus floridanus) feeds on herbaceous material, such as grasses and forbs, during the summer, and shifts to woody plant parts during the winter (Chapman et al., 1980; Myers, 2000). The eastern woodrat's (Neotoma floridana) diet consists of leaves, bark, fruits and seeds; the woodland vole (Microtus pinetorum) eats tubers, roots, seeds, leaves, and nuts. The beaver feeds on tree bark, leaves and aquatic vegetation (Allen, 1983; Myers et al., 2000). Species in this guild may consume large amounts of vegetation relative to their body size, because of either high metabolism or population density, and so should be considered to have impacts on the plant community that are potentially as significant as those of the larger herbivores.

Predators upon this guild include a variety of carnivorous and omnivorous mammals and herptiles, as well as raptors (Brillhart and Kaufman, 1994; INHS, 1998; Myers et al., 2000). For instance, mammalian predators upon the eastern cottontail and black-tailed jackrabbit include the 
gray fox (Urocyon cinereoargenteus), coyote (Canis latrans), bobcat (Felis rufus), mink (Mustela vison), and mountain lion (Felis concolor). Other lagomorph predators include the great horned owl (Bubo virginianus), the barred owl (Strix varia), and a variety of hawks (Godin, 1977; Dunn et al., 1982; Janes, 1985; Giusti et al., 1992). Timber rattlesnake (Crotalus horridus), garter snake (Thamnophis sirtalis), raccoon (Procyon lotor), badger (Taxidea taxis), the striped skunk (Mephitis mephitis), and the Virginia opossum (Didelphis virginiana) will also preferentially take nestlings as well as adults (Vorhies and Taylor, 1933; Lechleitner, 1959; Rue, 1965).

\subsubsection{Omnivorous Mammal Guilds}

Omnivorous mammals were also divided into two separate categories based on differences in body size, to aid in the distinctions between both predators and feeding habits.

\subsubsection{Omnivorous Mammal Guild 1-Larger Omnivores}

The larger omnivores at the TPP are the coyote (Canis latrans), the Virginia opossum (Didelphis virginiana), the striped skunk (Mephitis mephitis), the raccoon (Procyon lotor), the nine-banded armadillo (Dasypus novemcinctus) and the gray fox (Urocyon cinereoargenteus). These species all feed on invertebrates, small mammals, fish, birds, carrion, and various parts of plants (Myers et al., 2000). The opossum and raccoon are particularly opportunistic species, and are selective feeders when food is abundant, and more generalist when food is scarce (Lotze and Anderson, 1970; Chapman and Feldhamer, 1982). The most important prey species by weight for the gray fox is eastern cottontail (Sylivilagus floridanus), followed by white-tailed deer (Odocoileus virginianus) and rodents, although terrestrial invertebrates and a variety of plant material are also taken (Trapp and Hallberg, 1975; Greenberg and Pelton, 1991). Mammals, particularly lagomorphs and rodents, are the most significant portion of coyote diets, but insects and vegetation (berries and grasses) are also taken in significant amounts (Bekoff, 1977; Brillhart and Kaufman, 1994).

The members of this guild are infrequently preyed upon (Davis and Schmidly, 1994). The raccoon is prey to mountain lion (Felis concolor), bobcat (Felis rufus), coyote (Canis latrans), and owls (Lotze and Anderson, 1970). The Virginia opossum is prey to owls and the gray fox (Davis and Schmidly, 1994). The gray fox is occasionally taken by coyote and bobcat, and pups are taken by bobcat and great horned owl (Bubo virginianus), and possibly large hawks (Trapp and Hallberg, 1975). Coyotes are occasionally preyed upon by mountain lions (Banfield, 1974).

\subsubsection{Omnivorous Mammal Guild 2-Smaller Omnivores}

All of the mammals in this guild are rodents, including the fox squirrel (Sciurus niger), the 13-lined ground squirrel (Spermophilus tridecimlineatus), and various species of rats and mice. Over the entire guild, diet includes insects and other invertebrates, small vertebrates, carrion (in the case of the 13-lined ground squirrel), seeds, fruit, flowers, nuts, and other plant products (Myers et al., 2000). The hispid cotton rat (Sigmodon hispidus) feeds on stems, foliage, and seeds, as well as occasional insects and small vertebrates (Martin et al., 1951; Whitaker, 1980). The deer mouse (Peromyscus maniculatus) mainly prefers arthropods and seeds, although it will also consume nuts, berries, other small fruits, and fungi (Whitaker, 1980). Fox squirrels feed on a variety of plant material, insects, bird eggs, and fungi (Chapman and Feldhamer, 1982; Myers et 
al., 2000). The 13-lined ground squirrel consumes grasses (especially in early spring), seeds, and many insects (especially grasshoppers) and other animal matter (Timm and Pisani, 2000).

These species are prey to larger omnivorous and carnivorous mammals, snakes, and raptors (Myers et al., 2000). For instance, significant predators of the hispid cotton rat include Swainson's hawks (Buteo swainsonii), red-tailed hawk (B. Jamaicensis), and the short-eared owl (Asio flammeus) (Smith and Hanebrink, 1982; Bednarz, 1988; Toland, 1990). Relatively few predators can regularly capture adult fox squirrels; species include bobcat (Felis rufus), gray fox (Urocyon cineoargenteus), hawks, and owls. Juvenile fox squirrels are taken by raccoons, opossums, rat snakes (Elaphe obseleta), and bullsnakes (Pituophis melanoleucus) (Chapman and Feldhamer, 1982; Weigl et al., 1989).

\subsubsection{Carnivorous Mammal Guilds}

Species in these guilds exhibit clear differences in diet and body size, and have been divided accordingly.

\subsubsection{Carnivorous Mammal Guild 1a-Fossorial Invertivores}

This guild consists of two burrowing species, the eastern mole (Scalopus aquaticus) and the least shrew (Cryptotis parva). The least shrew feed principally upon insects, earthworms, snails, and carrion. Similar to the shrew, the eastern mole eats snails, earthworms, adult insects and other invertebrates, as well as larval insects and earthworms (Davis and Schmidly, 1994; Timm and Pisani, 2000). These species are subject to predation by larger herptiles, carnivorous and larger omnivorous mammals, and raptors (Timm and Pisani, 2000).

\subsubsection{Carnivorous Mammal Guild 1b-Flying Invertivores}

Two species of bat, the evening bat (Nycticeius humeralis) and the red bat (Lasiurus borealis), make up this guild. Their diets are restricted to flying insects (Davis and Schmidly, 1994; Myers et al., 2000). Hawks, owls, opossums, raccoons, and snakes are all predators of both species (Myers et al., 2000; Timm and Pisani, 2000).

\subsubsection{Carnivorous Mammal Guild 2-Large Predators}

Species in this guild are the badger (Taxidea taxus), bobcat (Felis rufus), mink (Mustela vison), and mountain lion (Felis concolor). They feed on a variety of species at lower trophic levels. Important food items for the mink include muskrats (Ondantra zibethicus), voles (Microtus spp.), eastern cottontail (Sylvilagus floridanus), fish, birds, frogs, and insects (Chapman and Feldhamer, 1982). Bobcats will take almost any available prey, including insects, fish, herptiles, birds, and mammals, although a wide variety of mammalian prey is most common, in particular the eastern cottontail (Chapman and Feldhamer, 1982; Myers et al., 2000). Mountain lions feed primarily on large ungulate species, especially deer; however, a variety of other mammals and birds will also be taken, including other carnivores (Lindzey, 1987). Badgers commonly prey on small vertebrates, especially fossorial rodents, as well as fish, snakes, lizards, carrion, insects, and eggs and nestlings of ground-nesting birds (Long, 1973; Long and Killingley, 1983). 
Predation upon the large carnivorous mammals at the TPP, other than that of humans, is probably extremely rare. Raptors and other large carnivorous and omnivorous mammals may take juveniles (Myers et al., 2000).

\subsubsection{Omnivorous Herptile Guild}

This guild is made up of two species of turtle, the ornate box turtle (Terrapene ornata), and the three-toed box turtle (Terrapene carolina). The three-toed box turtle eats berries and fungi, as well as earthworms, snails, slugs, and insects. The ornate box turtle tends to be more carnivorous, eating insects, snails, earthworms, bird eggs and hatchlings, and carrion, as well as vegetation (INHS, 1998). This guild has few predators, although coyotes and badgers will take the limbs of these turtles (Dawson, 2000).

\subsubsection{Carnivorous Herptile Guilds}

\subsubsection{Carnivorous Herptile Guild 1-Invertivores}

A variety of lizards, frogs, toads, and snakes are found in this guild, and the array of invertebrate prey is similarly diverse. For instance, the brown snake (Storeria dekayi) feeds on earthworms and slugs, while the flathead snake (Tantilla gracilis) eats scorpions, spiders, centipedes and other small arthropods. The skinks (Eumeces spp., Scintella lateralis) feed on arthropods and spiders, while the Texas horned lizard (Phrynosoma cornutus) preys exclusively on ants (INHS, 1998).

Several species in this guild bear special mention for their exclusive focus on belowground invertebrates. The following species are known to be fossorial: the great plains narrowmouth toad (Gastrophryne olivacea), the lined snake (Tropidoclonium lineatum), the rough earth snake (Birginia striatula), and Strecker's chorus frog (Pseudacris streckeri) (INHS, 1998).

Predators on this guild include snakes and lizards from the carnivorous herptile guild 2 (below), raptors, and omnivorous and carnivorous mammals (INHS, 1998).

\subsubsection{Carnivorous Herptile Guild 2-Other Carnivores}

This guild also contains lizards and frogs, although the major constituents are the fifteen species of snake that may be found in this guild. Common vertebrate prey includes rodents and other small mammals, smaller herptiles and herptile eggs, fish, and birds and bird eggs (INHS, 1998; Cavitt, 2000). Several species are also distinguished by additionally taking invertebrates as prey: the bullfrog (Rana catesbeiana), the coachwhip (Masticophis flagellum), the garter snake (Thamnophis sirtalis), the eastern collared lizard (Crotaphytus collaris), the ringneck snake (Diadophis punctatus), the western glass lizard (Ophisaurus attenuatus), and the yellowbelly racer (Coluber constrictor). The only fossorial species is the crayfish frog (Rana areolata), which feeds on crayfish and small amphibians and reptiles (INHS, 1998).

Raptors, snakes, and omnivorous and carnivorous mammals feed upon this guild (INHS, 1998). 


\subsubsection{Bird Guilds}

Birds (Aves) are the most diverse taxonomic group of vertebrates at the TPP, with well over 100 species found at the Preserve. Despite this diversity, only a small number of species maintain breeding populations. Four species comprise the majority of all individuals found in tallgrass prairie: the dickcissel (Spiza americana), the brown-headed cowbird (Molothrus ater), the grasshopper sparrow (Ammodramus savannarum), and the eastern meadowlark (Sturnella magna) (Zimmerman, 1993); these species are all omnivores. Rotenberry and Weins (1980) demonstrated that these particular four species show little niche overlap or resource partitioning.

Three bird guilds have been designated: the omnivorous bird guild, the carnivorous bird guild 1 (invertivores), and the carnivorous bird guild 2 (raptors). Data regarding dietary preferences of these species were taken from Peterson (1980), Risser et al. (1981), Myers et al. (2000), and Robinson (2000). Members of the first two guilds share similar predators - a combination of mammals, herptiles, and raptors, although some of these predator groups feed selectively on eggs or chicks rather than mature individuals.

\subsubsection{Omnivorous Bird Guild}

Species in this guild span a variety of feeding habits and morphologies, from waterfowl to tree-dwellers. Most species feed in the ground and shrub stratum, although several (e.g., woodpeckers) feed in the canopy or subcanopy (Zimmerman, 1993). Diets include plant parts, invertebrates, as well as many vertebrate species. For instance, the gadwall (Anas strepera) feeds on plants, insects, and amphibians; the king rail feeds primarily on insects such as beetles, grasshoppers, and dragonfly nymphs, although vegetation and frogs are also eaten (Robinson, 2000). House sparrows (Passer domesticus) eat various kinds of seeds supplemented by some insects. Wood thrushes (Hylocichla mustelina) feed preferentially on soil invertebrates and larvae, but will eat fruits in late summer, fall, and late winter, and will occasionally feed on arboreal insects, snails, and small salamanders. Blue jays (Cyanocitta cristata) are a generalist species that eat fruits, nuts, seeds, insects, mice, frogs, and other small birds and bird eggs. The American crow (Corvus brachyrhynchos) is also a generalist species; its diet includes fruit, grain, snails, salamanders, small birds, eggs, mice, toads, and large quantities of insects and carrion (Myers et al., 2000).

Predators on this guild include other carnivorous and omnivorous birds and mammals, as well as snakes. Predators of particular importance include striped skunk, coyote, fox, badger, raccoon, snakes, hawks, owls, gulls and crows (Robinson, 2000).

\subsubsection{Carnivorous Bird Guild 1-Invertivores}

These are mainly smaller birds such as flycatchers, swallows, and warblers, although larger birds such as sandpipers are also found. These species exhibit a variety of feeding and nesting heights; however, many are aerial feeders or reside in the canopy (Zimmerman, 1993). Diets span the range of invertebrate species. For instance, the blue-gray gnatcatcher (Polioptila caerula) eats mostly small insects (mainly cicadas, aphids, and beetles) and spiders. Barn swallows (Hirundo rustica) feed largely on Diptera (flies) and other flying insects (Myers et al., 2000). The eastern bluebird (Sialia sialis) mainly preys upon arthropods, most frequently grasshoppers and crickets, but also butterflies, moths, spiders, and beetles (Pinowski, 1979). 
Predators, as already mentioned, are similar to the omnivorous birds. For example, the upland sandpiper (Bartramia longicauda) suffers predation upon eggs and chicks by coyotes, badgers, raccoons, mink, and skunks. Crows, sharp-shinned hawks, Cooper's hawks, northern harriers, and kestrels are known to be threats to both adults and young (Carter et al., 1992). The loggerhead shrike (Lanius ludovicianus) suffers predation of young and eggs by other birds such as crows (Porter et al., 1975), and the eastern bluebird suffers nest failure due to raccoon and house sparrow predation (Pinowski, 1974).

\subsubsection{Carnivorous Bird Guild 2-Raptors}

This guild includes the bald eagle (Haliaeetus leucocephalus), the peregrine falcon (Falco peregrinus), numerous species of hawks and owls, and several other birds of prey. While prey varies between species, these birds feed mainly on small mammals, herptiles, fish, and some smaller birds, although invertebrates and carrion are also eaten (especially in the case of the turkey vulture, Cathartes aura) (Myers et al., 2000). The bald eagle (Haliaeetus leucocephalus) prefers fish, and also preys on small mammals, waterfowl, small birds, and carrion (especially deer). The burrowing owl (Athene cunicularia) preys on small mammals such as lagomorphs and rodents, birds, reptiles, and a variety of insects and arachnids. The Mississippi kite (Ictinia mississippiensis) primarily preys on insects such as grasshoppers, cicadas, and beetles; however, frogs, toads, lizards, snakes, other birds and carrion are also eaten (Robinson, 2000).

Adult individuals in this guild have no natural predators at the TPP. Juveniles and eggs are sometimes preyed upon, particularly in ground-nesting species such as the northern harrier (Circus cyaneus) and the short-eared owl (Asio flammeus). Such predators include other raptors, crows and jays, snakes, and omnivorous mammals (Robinson, 2000).

\subsubsection{Invertebrate Guilds}

Invertebrates likely serve an extremely important role in the community at the TPP. At the Konza Prairie LTER, 62 families and more than 300 species of insects have been classified, and it is estimated that more than 3000 species exist at the site (Kaufman et al., 1998); the TPP is likely to be very similar. Indeed, Arenz (1995) asserts that $75 \%$ of all species at the TPP are animals, and of these, 95\% are insects. Findings already indicate that insects, as a whole, have a large influence on tallgrass prairie plants (Hartnett and Fay, 1998); it is also possible that particular species of insect serve keystone functions in the community.

Despite the astonishingly diverse array of taxa and feeding mechanisms, only two guilds have been developed for invertebrates: the aboveground invertebrate guild and the soil invertebrate guild. The primary criterion for partitioning species into guilds, trophic level, was abandoned in favor of a criterion based on vertical spatial distribution, in an effort to simplify the connections between the invertebrate guilds and higher trophic levels.

Instead of delineating invertebrate guilds based on feeding habit, the additional complexities found within each of these two guilds are discussed by dividing each guild into several feeding categories. An exhaustive species list was not available for invertebrates at the TPP; guilds, categories, and descriptions are based on species found at the analogous Konza LTER (http://climate.konza.ksu.edu) and several other resources (Pearse et al., 1987; Preston-Mafham, 
1993; Daly et al., 1998). For this reason, species lists for the invertebrates have not been included in Table 2.

\subsubsection{Terrestrial Invertebrate Guild}

At the TPP, the main categories of aboveground invertebrates are the herbivores, detritivores/omnivores, carrion feeders, nectar/pollen feeders, and predators. Descriptions of each follow.

3.1.7.1.1. Herbivores. Many different types of phytophagous invertebrates are found in the aboveground compartment of the TPP ecosystem. These include grass feeding, forb feeding, and tree feeding species, and within these divisions, foliage, seed, flower, stem, and fruit feeders, as well as gall forming insects. Major orders represented include Orthoptera (crickets and grasshoppers), Hemiptera (true bugs), Homoptera (aphids), and Coleoptera (beetles). Also included in this category are pulmonates from the order Stylommatophora (slugs and snails).

3.1.7.1.2. Detritivores and Omnivores. This category includes species which are xylophagous (feeding on dead woody plant material), phytosaprophagous (feeding on decaying vegetable matter), and catophagous (feeding on feces or dung), as well as the classic omnivores and detritivores (who may also feed on associated microbiota found in decaying matter). Main orders include Hymenoptera (ants), Isoptera (termites), Orthoptera (crickets), and Blattodea (roaches), as well as some species of slug and snail (Stylommatophora). Also of interest are the dung beetles (order Coleoptera, family Scarabaeidae), who take dung from the surface and move it belowground, hence falling into both the aboveground and belowground guilds.

3.1.7.1.3. Carrion Feeders. Carrion feeders are mainly composed of flies (Diptera) and beetles. The carrion feeding beetles are primarily from the family Silphidae. Carrion feeders may be distinguished from the detritivorous category above in that they are zoosaprophagous, i.e. they feed strictly on dead animal matter. Some overlap may exist between this category and the detritivorous category.

3.1.7.1.4. Nectar and Pollen Feeders. Bees and some wasps (order Hymenoptera), butterflies and moths (order Lepidoptera), and many beetle groups (order Coleoptera) are known to feed on nectar and pollen. In particular, the butterflies have been well studied at the TPP; Arenz (1995) suggests that they may serve as an excellent indicator group, given their high degree of measurability and social relevance. A butterfly monitoring program has already been initiated at the preserve.

3.1.7.1.5. Predators. Predatory invertebrates at the TPP include spiders (Arachnida), carabid beetles (Carabididae), some species of wasp (Hymenoptera), flies (Diptera), and grasshoppers (Orthoptera). These feed mainly on other invertebrates, although some taxa may be flesh eating.

\subsubsection{Soil Invertebrate Guild}

Several main categories of soil invertebrates may be found at the TPP: herbivores, xylem suckers, detritivores, and predators. Microscopic organisms, such as the microarthropods and nematodes, have been specifically excluded, as trophic linkages are negligible between these mesofauna and the macroinvertebrates. However, it should be noted that both microarthropods and nematodes possess their own trophic structure including herbivores, fungivores, and 
predators. Nematoda, in particular, is recognized as the second largest of the animal phyla (Pearse et al., 1987), and may play a significant role in terms of energy flow in the TPP system.

3.1.7.2.1. Herbivores. This category comprises the largest fraction of soil invertebrates in terms of biomass. These phytophagous invertebrates are composed mainly of beetles in the families Scarabaeidae (white grubs), Elateridae (wireworms), Chrysomelidae (root worms) and Curculionidae (weevils) (Seastedt, 1984). These species feed on the roots and underground stems of vegetation. All of these species spend the adult portion of their life cycles above ground (Daly et al., 1998).

3.1.7.2.2. Xylem Suckers. This second phytophagous category consists of the cicadas, in the family Cicadidae. These insects are the second most abundant in terms of biomass. Cicadas feed by sucking the xylem from the roots of plants, causing them to filter massive quantities of water to extract nutrient content. Cicadas offer a high potential for use as bioindicators in contaminated soils because of their relatively long life cycle (4-6 yr) and the fact that their tissues should substantially represent the content of soil water. Cicadas also emerge to live their adult lives above ground (Callaham et al., 2000).

3.1.7.2.3. Detritivores. This category is primarily composed of earthworms. Taxa found in tallgrass prairie that are native to North America include Diplocardia spp. and Bimastos spp., while introduced European taxa include Aporrectodea spp. and Octolasion spp. (James and Cunningham, 1989; Callaham and Blair, 1999). All of these taxa feed on plant material in various states of decay, much of it as advanced as soil organic matter. Another group of detritivores includes the dung beetles, also part of the family Scarabaeidae. These species take detritus from aboveground and move it belowground, and so fall into the category of both terrestrial and soil invertebrates. Finally, one may find members of the class Diplopoda, or millipedes (Seastedt, 1984).

3.1.7.2.4. Predators. The soil entomophages are nearly all arthropods. Beetle predators include members of the Carabidae, Cicindellidae, and Staphylinidae families. Several varieties of centipede (class Chilopoda) are also common belowground predators (Seastedt, 1984).

\subsection{Beta Guilds}

The beta guilds (Table 3) were delineated by using observed distribution data taken from ONHI (1993), as well as using information from other sources regarding general habitat preference (see Appendix $\mathrm{C}$ for a list of sources). Beta guilds begin to offer an expansion upon the one-dimensional analysis of food relationships found in the alpha guilds, by providing insight into another key requirement of species: habitat. Loss of habitat, rather than loss of prey species, may be a more critical impact of oil and brine spills on the TPP, particularly the spills that directly affect the sensitive and small habitats. The rather small habitats represented by the five non-prairie guilds may be of either extreme ecological significance, as reservoirs of high species diversity (e.g., riparian zones) or as fundamental units supporting overall community and ecosystem structure and function. They could also enjoy social importance, as areas harboring public interest or value. The location of oil and brine spills relative to these habitats is uncertain at this time. 
As mentioned earlier, the use of observed and induced data for species distribution creates a combination of realized and fundamental niches for these species, and should therefore be used only as a general guideline. Many species, particularly those with larger home range sizes, are likely to be found outside their preferred habitat, particularly during dispersal, times of food shortage, or other disturbance. Seasonal usage of various habitats by birds was available for the Konza Prairie; this data has been included in Appendix A.

\subsection{Plants}

Table 4 shows the relative frequency and cover of the 126 most frequent plant species at the preserve (Palmer, unpublished data). The most common species, occurring in more than 90 percent of the plots, are big bluestem (Andropogon gerardii, 97.4\% of plots), tall dropseed (Sporobolus compositus, 97.4\%), yellow wood sorrel (Oxalis dillenii, 96\%), western ragweed (Ambrosia psilostachya, 95.4\%), green milkweed (Asclepias viridis, 92.1\%), and panic grass (Dichanthelium oligosanthes, 91.4\%). The species with the largest percentage cover are big bluestem (4\%), tall dropseed (2.8\%), little bluestem (Schizachyrium scoparium, 2.3\%), western ragweed (1.5\%), and indian grass (Sorghastrum nutans, 1.3\%).

Plants were not divided into guilds for several reasons. To begin with, because the area of the preserve directly impacted by oil or brine spills is relatively small, it was anticipated that the indirect (community-level) impacts on plants would be negligible (except perhaps in the case of locally rare species). Second, grassland plant communities are not easily divisible into welldefined guilds (Simberloff and Dayan, 1991). One could divide species using classic approaches such as carbon pathway (i.e., C3 vs. C4), life history (i.e., perennials vs. annuals), or life form (i.e., grass, forb, shrub, tree) (Wilson, 1999); however, these divisions would lend little insight into the impact of spills on animal communities. Finally, designation of guilds based on animal consumption (e.g., palatability) was limited by data gaps, local (as well as seasonal) variability in diet, and high degrees of dietary overlap.

It is recommended that the plant community be analyzed in more detail in the context of the selected endpoint species and the location of the oil and brine spills.

\subsection{Trophic Model}

Table 5 shows the community food web at the TPP, describing the binary feeding relationships (prey/not prey) between the guilds in the community (Solow and Beet, 1998). In addition to the animal guilds, two additional compartments were added to the trophic model to complete the analysis: (1) plants and fungi, and (2) detritus and carrion. Figure 1 shows source webs based on four guilds: aboveground invertebrates, belowground invertebrates, large herbivorous mammals, and small herbivorous mammals. A source web "...includes one or more kinds of organisms, the organisms that eat them, their predators and so on" (Pimm et al., 1991). These four webs effectively trace nearly all of the possible trophic pathways from basal species to top predators; for convenience, all of the trophic pathways have been depicted in Appendix E. As can be seen, the inclusion of invertebrates generates much greater web complexity.

The overall number of links in the TPP system is 63, resulting in a connectance of 0.246 , which is well within the typical range (0.06-0.32) of empirical observations (Williams and 
Martinez, 2000). The minimum chain length is 2 (D:CB2), while the maximum chain length is 8 (several different pathways); typical chain length at the TPP ranges from 3 to 5 (see Figure 1 and Appendix E). The linkage density, or average number of links per guild, is 3.94, nearly double the typical observed density (Schoener, 1989; Pimm et al., 1991). This higher density is likely attributable to the greater degree of aggregation of species in guilds relative to "trophic species." Indeed, Pimm et al. (1991) note that aggregation along taxonomic affinities (as was done in the guilds) can alter web properties, and further, that temporally cumulative webs usually overestimate linkage density relative to time-specific snapshots. Not surprisingly, cycling (e.g., $a$ eats $b, b$ eats $c, c$ eats $a$ ) and compartmentalization (i.e., independence of food chains) were not found in the TPP system (see Pimm, 1982 or Schoener, 1989 for a discussion of these phenomena and their rarity). Looping (the empirically rare phenomenon of feeding on members of one's own guild), on the other hand, was common, being found in five guilds: the aboveground invertebrates, the belowground invertebrates, the large omnivorous mammals, the omnivorous birds, and guild 2 of the carnivorous herptiles. Again, this pattern may be attributable to the fact that the guilds are composed of multiple trophic species (Schoener, 1989).

We considered any guilds preying upon three or fewer guilds to be a feeding specialist. On this basis, the division between specialist and generalist feeders is nearly an even split: nine of the guilds feed on three or fewer guilds/compartments, while the remaining seven guilds feed on four or more, averaging 6.7. All of the specialist guilds restrict their diets to either invertebrates, plants or detritus, or some combination; the generalist guilds include omnivores (preying upon a variety of plants, carrion, animals) and carnivores (feeding on a combination of vertebrates and invertebrates). Specialist guilds may be more sensitive to the loss of an individual prey species (or an entire guild) than generalist guilds, particularly to the extent that the various species in each guild feed on identical prey species. Different definitions for a "specialist" guild may also yield varying results.

\subsubsection{Aggregation of Guilds}

Based on this trophic model, guilds may be aggregated using various criteria to offer additional insights into community structure in the TPP. As an example, certain guilds were aggregated into "metaguilds," using two methods: (1) based on shared prey species, and (2) based on shared predator species.

\subsubsection{Similar Prey Species}

By grouping together guilds based on shared prey species, two metaguilds can be defined: the herbivorous mammals, and the invertivores (Table 6). The first metaguild, as the name suggests, is composed of the three plant-eating mammalian guilds. The second metaguild is made up of the invertivorous herptiles and the invertivorous birds. This metaguild feeds on both aboveground invertebrates and soil invertebrates.

Taxonomic affinity has been ignored by the metaguild groupings. As discussed earlier, taxonomy has been criticized as an arbitrary convention for grouping species (Wilson, 1999). However, these metaguilds closely follow the first criterion in the classic definition of an alpha guild i.e., all members of a metaguild use the same class of resources. The metaguilds therefore show all species sharing similar food requirements. Both metaguilds consist of species that are relative specialists compared against many of the other guilds found at the TPP; as mentioned 
above, such species may be more sensitive to the loss of an individual prey species, especially those metaguild members that feed on identical prey. This is limited by the fact that these metaguild classifications do not elucidate the specific species that are preyed upon; nor do they address the method or quantity of food taken or other issues such as resistance to disturbance, mobility, and other forms of adaptability of certain predators. They do, however, offer the researcher a procedure for quickly identifying several functional groups in the TPP ecosystem based on general diet.

\subsubsection{Similar Predator Species}

Each metaguild in this category shares identical predators. This approach turns the classic guild concept on its head; it categorizes species based on how they are used as a resource, as opposed to how they use resources, creating a sort of "inverse guild." Four different metaguilds were found (Table 6):

- Metaguild A. This metaguild consists of the large herbivorous mammals and the omnivorous herptiles (turtles), and serves as prey to the large omnivorous and carnivorous mammals.

- Metaguild B. This metaguild is made up of the small herbivorous and omnivorous mammals, the fossorial invertivorous mammals, and the large carnivorous herptiles. Large omnivorous and carnivorous mammals, flesh-eating herptiles, omnivorous birds, and raptors prey upon this metaguild.

- Metaguild $C$ (Non-raptorial birds). These are the omnivorous and invertivorous birds. They are preyed on by various omnivorous and carnivorous mammals, birds, and herptiles.

- Metaguild D (Top predators). This metaguild consists of the raptors and large carnivorous mammals, and has no natural predators.

These metaguilds again offer the researcher a rapid method for identifying functional groups of species. They also offer insight into which guilds are potentially impacted by the loss of a particular species from one of these metaguilds. The impact will vary based on interaction strength between the two species (i.e., the loss of a particular species will have less impact on a generalist than a specialist). Also, while members of these metaguilds share identical guilds of predators, specific predator species may vary. It should be noted that Metaguilds B and C share extremely similar predator guilds.

\subsubsection{Considerations for the Selection of Endpoint Species}

In considering the selection of endpoint species based on the food web at the TPP, we refer back to the four criteria for endpoint selection: (1) social relevance, (2) biological relevance, (3) predictability and measurability, and (4) sensitivity to disturbance. The following discussion will address implications of the trophic model relative to these criteria, although it does not intend to be comprehensive.

This trophic model does not explicitly examine social relevance and predictability/measurability. However, it is clear that bison enjoy high social relevance; they are also easily measured and biologically important to the TPP community. Butterflies are another 
socially relevant and measurable species; indeed, the TPP supports a pre-existing volunteer monitoring program (Arenz, 1995). Finally, the four most common species of prairie bird (the dickissel, the brown-headed cowbird, the grasshopper sparrow, and the eastern meadowlark) may provide good indicators as they are likely to be highly measurable.

The trophic model more directly addresses biological relevance, and to a limited extent, sensitivity to disturbance. As mentioned above, it is clear from the literature that bison play a large role in maintaining community structure and function. Bison are considered "keystone engineers," both impacting the integrity of the TPP ecosystem to an extent far greater than their size or number in the system, as well as modulating available resources by causing physical state changes in biotic and abiotic systems (Collins and Benning, 1996; Collins and Steinauer, 1998; Knapp et al., 1999). Bison are part of a relatively simple trophic relationship: they feed on the lowest trophic level, the plants, and have few predators (see Figure 1c and Section 3.1.1.1). However, bison populations are regulated by humans at the preserve, and so are unlikely to be as sensitive to disturbance as other species.

Other herbivorous and omnivorous species may not have a large direct effect on plant species diversity (Gibson et al., 1990). However, small-scale disturbances such as small mammal burrows are important to enhancing species diversity and heterogeneity in the tallgrass prairie (Hamilton, 1996). In complex food webs such as that found at the TPP, many feedback mechanisms are likely to exist, and disturbances such as oil or brine spills may not have easily predictable effects on the community structure (Pimm et al., 1991). In some cases, the species whose removal may have the largest impact on the community may be those with weak interaction strength (Berlow, 1999). Interaction strength is the relative feeding frequency of a given species upon other species. Berlow shows, through analysis of published data, the greatest variation in species effect occurs for species that are considered to be weak interactors. This may be because these species magnify spatiotemporal variation or that they play dampening or stabilizing roles in the overall community structure.

Determining which species are weak interactors is confounded by the fact that food web models regard feeding as one-dimensional; that is, a species is subject to a binary designation of prey/not prey. Interaction strength has not been considered in these designations. The population density of predator species is not considered; nor is the quantity of different prey consumed by each individual. As a result, various guild members may not have analogous impacts on specific prey species. In addition, as mentioned earlier, certain species within a guild may be more adaptable to changes in food resources, or have a greater ability to survive in the absence of suitable prey. Statistical approaches could be used to determine interaction strength; however, data are scarce for many species. For a further discussion, see Appendix C.

Despite this shortcoming, the distinction between feeding specialists and generalists may be important, since specialist species presumably have stronger interaction strengths with their associated prey species than do generalists. In addition, specialist species may be particularly sensitive if their prey is severely impacted by the spills (e.g., specialist herbivores whose feeding area contains a brine spill). Specialist guilds may be determined by examining Table 5 .

Pimm et al. (1991) assert that complex webs (those with high linkage density, or many generalist species) will experience more secondary extinction as a result of loss of species at the top of the food web, rather than the bottom. Simple food webs, alternately, are more sensitive to 
the loss of primary producers. At limited spatial scales (such as individual habitat areas within the TPP), food web structures tend to be more simple, causing plants to grow in importance; however, at the larger spatial scale of the entire preserve, the loss of top predators may be more important. It is unlikely that the limited spatial extent of the oil and brine spills will have a dramatic impact on top predators due to their large home ranges. Further, determining the topdown influence that these species may exert using a cascade model is complicated by the variety of food-chain lengths of which they are a part.

Several specific species may serve as excellent indicators based on sensitivity to disturbance. Cicadas are good indicators of soil contamination, for reasons discussed in Section 3.1.7.2.2. Animals that potentially feed or burrow in contaminated soil may also be good indicators for impacts from oil and brine spills. Such fossorial species are identified in the descriptions of the alpha guilds (Section 3.1).

Finally, two methods of selecting endpoint species bear discussion: selecting representative species from each functional group ("guild indicators"), and selecting representative species from important trophic pathways (see Figure 1 and Appendix E). Simberloff and Dayan (1991) warn that diversity within a guild may preclude selection of a guild indicator. For example, the omnivorous bird guild contains enough diversity that species probably differ sufficiently in ways other than resource use to cause different responses to habitat change or other stressors. On the other hand, certain guilds, such as the Herbivorous Mammal Guild 1a (large grazers), may be homogenous enough to transcend this limitation. However, even in cases where the species are sufficiently similar that a representative species may be selected, the loss of that alpha guild member could potentially result in a decrease in interspecific competition experienced by other members, causing reactions in other species which are opposite, not analogous, in sign.

Selection of species which are representatives from each of all (or several of the important) trophic pathways, on the other hand, potentially offers a satisfyingly comprehensive approach toward analyzing the impacts of spills at the TPP. Care should be taken to ensure that each representative species is highly relevant based on the four endpoint criteria.

\subsubsection{Other Considerations}

Several additional points help inform the analysis derived from the use of this trophic model. First, the species found at the preserve, and the relationships between and among them, vary over time. At the Konza Prairie LTER, Knapp et al. (1998) found that bird, small mammal, and grasshopper populations are highly spatially and temporally variable. Risser et al. (1981) found similar results with rodents at the TPP. As mentioned before, the trophic model as it has been constructed is a "cumulative web" (Pimm et al., 1991). Species lists were collected from two time periods, one immediately before bison reintroduction (ONHI, 1993), and the other three years after reintroduction (Nature Conservancy, 1996). Bison therefore may have caused, or may cause in the future, a shift in community structure that is not represented by this model. Further, other temporal variations and disturbance cycles are likely to influence community structure and function. In particular, fire is an important influence that alters the structure of plant, insect, and small mammal communities (Evans, 1988; Kaufman et al., 1988; Gibson et al., 1993).

Consideration of continuing changes in the communities at the TPP will assist in resolving these issues. Auxiliary information regarding particular species (e.g., species information in 
Section 3.1, and seasonal bird distribution data in Appendix A), temporal cycles, etc., should be considered when undertaking analysis using the trophic model. Further research into particular species (especially endpoint species) and temporal dynamics may also be desirable, as discussed in Appendix C.

\subsubsection{Expanding the Model: Combining Alpha and Beta Guilds}

This model may also become more useful by considering the beta guilds in addition to the alpha guilds. Toward this purpose, species listings in the beta guilds (Table 3) provide alpha guild information, with members of each alpha guild grouped together within the beta guild categories. Developing trophic models specific to each beta guild, and examining the relationships between them, could offer a substantially increased understanding of community relationships and the effects of oil and brine spills, as predator/prey interactions may be significantly different at limited spatial scales. Constructing trophic models for the beta guilds in which contaminant spills are located may be particularly useful. Unfortunately, the specific locations of these spills relative to the six beta guilds are unknown at this time.

\section{Acknowledgements}

The authors would like to thank Pat O'Brien and Sara McMillen of Chevron, and other members of the PERF 99-01 team for intellectual support and discussions while developing our project to investigate the role of size and distribution of remediation sites at natural gas and petroleum exploration and production facilities. The authors would also like to thank Nancy Comstock of the Department of Energy's National Petroleum Technology Office for financial support through the Natural Gas and Oil Technology Partnership Program. Bob Hamilton, the Director of Science and Stewardship at the TPP, provided useful contacts and other resources relevant to the preserve. Dr. Michael Palmer (Oklahoma State University) and Dr. Bryan Tapp (University of Tulsa) were also forthcoming with data and assistance. Tom Ashwood (Oak Ridge National Laboratory) provided additional species lists and insights into trophic relationships. Tom Ashwood and Dr. Rebecca Efroymson (Oak Ridge National Laboratory) provided review of the manuscript. Dr. Kristiina Vogt (University of Washington), provided ongoing insight and critical review of the document. An earlier draft of the document was reviewed by Dr. Palmer and Dr. Donald DeAngelis (USGS, University of Miami). 


\section{References}

Allen, A.W. 1983. Habitat Suitability Index Models: Beaver. (Revised), U.S. Department of the Interior, Fish and Wildlife Service, Washington, D.C. (FWS/OBS-82/10.30).

Arenz, C.T. 1995. "Initiation of a butterfly monitoring program at the Tallgrass Prairie Preserve, Osage County, Oklahoma," in Proceedings of the Oklahoma Academy of Science 75, 25-29.

Banfield, A.W.F. 1974. The Mammals of Canada. University of Toronto Press, Toronto, ON.

Bekoff, M. 1977. “Canis latrans,” Mammalian Species 79, 1-9.

Bednarz, J.C. 1988. "Swainson's hawk." In Proceedings of the Southwest Raptor Management Symposium and Workshop, R.L. Glinski, B.G. Pendleton, and M.B. Moss, Eds. NWF Scientific and Technical Series No. 11. (National Wildlife Federation, Washington, D.C.) May 21-24 1986, pp. 87-96

Berlow, E.L. 1999. "Strong effects of weak interactions in ecological communities," Nature 398, 330-334.

Bockstanz, L.M., and D.C. Cannatella. 2000. Herps of Texas. http://www.zo.utexas.edu/research/txherps/

Brillhart, D.E., and D.W. Kaufman. 1994. "Temporal variation in coyote prey in tallgrass prairie of eastern Kansas," Prairie Naturalist 26, 93-105.

Bryant, F.C., G. Van Vreede, T.J. Deliberto, and K.L. Gee. 1996. "Diets of female white-tailed deer in the Cross-timbers region," Prairie Naturalist 28, 125-139.

Callaham, M.A., Jr., and J.M. Blair. 1999. "Influence of differing land management on the invasion of North American tallgrass prairie soils by European earthworms," Pedobiologia 43, 507-512.

Callaham M.A, Jr., M.R. Whiles, C.K. Meyer, B.L. Brock, and R.E. Charlton. 2000. "Feeding ecology and emergence production of annual cicadas (Homoptera: Cicadidae) in tallgrass prairie," Oecologia 123, 535-542.

Carter, J.W., G. Hammerson, and D.W. Mehlman. 1992. "Upland Sandpiper," Wings Information Resources/Species Information and Management Abstracts. The Nature Conservancy. http://www.tnc.org/wings/wingresource/upsa.html

Cavitt, J.F. 2000. “Tallgrass prairie snake assemblages: food habits," Herpetological Review 31, $47-48$.

Chapman, J.A., and G.A. Feldhamer, Eds. 1982. Wild mammals of North America (The Johns Hopkins University Press, Baltimore, MD).

Chapman, J.A., J.G. Hockman, C. Ojeda, and M. Magaly. 1980. "Sylvilagus floridanus," Mammalian Species 136, 1-8. 
Collins, S.L., and T.L. Benning. 1996. "Spatial and temporal patterns in functional diversity," In Biodiversity: a biology of numbers and difference, K. Gaston, Ed. (Blackwell Science, Oxford).

Collins, S.L., and E.M. Steinauer. 1998. "Disturbance, diversity, and species interactions in tallgrass prairie," in Grassland Dynamics: long-term ecological research in the tallgrass prairie, A.K Knapp, J.M. Briggs, D.C. Harnett, and S.L. Collins, Eds. (Oxford University Press, Oxford).

Conant, R. and J.T. Collins. 1998. A Field Guide to Reptiles and Amphibians of Eastern and Central North America, 3rd ed., expanded (Houghton Mifflin, Boston).

Coppedge, B.R., and Shaw, J.H. 1998. "Diets of bison social groups on tallgrass prairie in Oklahoma," Prairie Naturalist 30, 29-36.

Cossel, Jr., J. 1998. Sonora semiannulata (Western Ground Snake). In Digital Atlas of Idaho-Version 1.01. http://imnh.isu.edu/digitalatlas/

Daly, H.V., J.T. Doyen, and A.H. Purcell. 1998. Introduction to Insect Biology and Diversity. (Oxford University Press, Oxford.

Damhoureyeh, S.A. and D.C. Hartnett. 1997. "Effects of bison and cattle on growth, reproduction, and abundances of five tallgrass prairie forbs," American Journal of Botany 84, 1719-1728.

Dawson, J. 2000. The Turtle Pages. http://www.theturtlepages.com

Davis, W.B., and D. J. Schmidly. 1994. The Mammals of Texas (Texas Parks and Wildlife Department, Austin, TX).

DeAngelis, D.L. 1992. Dynamics of nutrient cycling and food webs (Chapman and Hall, London).

Dunn, J.P., J.A. Chapman, R.E. Marsh. 1982. "Jackrabbits: Lepus californicus and allies," in Wild Mammals of North America: Biology, Management, and Economics, J.A. Chapman and G.A. Feldhamer, Eds. (The John Hopkins University Press, Baltimore, MD), pp. 124-145.

Evans, E.W. 1988. "Grasshopper (Insecta: Orthoptera: Acrididae) assemblages of tallgrass prairie: Influences of fire frequency, topography, and vegetation," Canadian Journal of Zoology 66, 1495-1501.

Finck, E.J., D.W. Kaufman, G.A. Kaufman, S.K. Gurtz, B.K. Clark, L.J. Mclellan, and B.S. Clark. 1986. "Mammals of the Konza Prairie Research Natural Area, Kansas," Prairie Naturalist 18, 153-166.

Gibson, D.J., C.C. Freeman, and L.C. Hulbert. 1990. "Effects of small mammal and invertebrate herbivory on plant species richness and abundance in tallgrass prairie," Oecologia 84, $169-175$.

Gibson, D.J., T.R. Seastedt, and J.M. Briggs. 1993. "Management practices in tallgrass prairie: large- and small-scale experimental effects on species composition," Journal of Applied Ecology 30:247-255. 
Giusti, G.A., R.H. Schmidt, and R.M. Timm. 1992. "The lagomorphs: rabbits, hares, and pika," in Silvicultural Approaches to Animal Damage Management in Pacific Northwest Forests. General Technical Report PNW-GTR-287, U.S. Department of Agriculture, Forest Service, Pacific Northwest Research Station, Portland, OR, pp. 289-307

Godin, A.J. 1977. Wild Mammals of New England (The John Hopkins University Press, Baltimore, MD).

Greenberg, C.H., and M.R. Pelton. 1991. "Food habits of gray foxes (Urocyon cinereoargenteus) and red foxes (Vulpes vulpes) in east Tennessee," Journal of the Tennessee Academy of Science 66, 79-84.

Hamilton, R.G. 1996. "Using fire and bison to restore a functional tallgrass prairie landscape," Transactions of the $61^{\text {st }}$ North American Wildlife and Natural Resources Conference. Wildlife Management Institute, New York, NY.

Hartnett, D.C., and P.A. Fay. 1998. "Plant populations: patterns and processes," in Grassland Dynamics: long-term ecological research in the tallgrass prairie, A.K Knapp, J.M. Briggs, D.C. Harnett, and S.L. Collins, Eds. (Oxford University Press, Oxford).

Illinois Natural History Survey (INHS). 1998. INHS Amphibian and Reptile Collection. http://www.inhs.uiuc.edu/cbd/herpdist/splist.html

James, S.W. and M.R. Cunningham. 1989. "Feeding ecology of some earthworms in Kansas tallgrass prairie," American Midland Naturalist 121, 78-83.

Janes, S.W. 1985. "Habitat selection in raptorial birds," in Habitat Selection in Birds, M.L. Cody, Ed. (Academic Press, Inc.), pp. 159-188.

Kaufman, D.W., P.A. Fay, G.A. Kaufman, and J.W. Zimmerman. 1998. "Diversity of Terrestrial Macrofauna," in Grassland Dynamics: long-term ecological research in the tallgrass prairie, A.K. Knapp, J.M. Briggs, D.C. Harnett, and S.L. Collins, Eds. (Oxford University Press, Oxford).

Kaufman, G.A., D.W. Kaufman, and E.J. Finck. 1988. "Influence of fire and topography on habitat selection by Peromyscus maniculatus and Reithrodontomys megalotis in ungrazed tallgrass prairie," Journal of Mammalogy 69, 342-352.

Knapp, A.K., J.M. Briggs, D.C. Hartnett, and S.L. Collins, Eds. 1998. Grassland Dynamics: long-term ecological research in the tallgrass prairie (Oxford University Press, Oxford).

Knapp, A.K., J.M. Blair, J.M Briggs, S.L. Collins, D.C. Hartnett, L.C. Johnson, and E.G. Towne. 1999. "The keystone role of bison in north American tallgrass prairie - bison increase habitat heterogeneity and alter a broad array of plant, community, and ecosystem processes," Bioscience 49, 39-50.

Lechleitner, R.R. 1959. Sex ration, age classes, and reproduction of the black-tailed jack rabbit. Journal of Mammology 40, 63-81.

LeClere, J. 2000. Reptiles and Amphibians of Minnesota. http://216.219.214.109/MinnesotaHerpetology/index.html 
Lindzey, F. 1987. "Mountain lion," in Wild furbearer management and conservation in North America, Novak, M, Baker, J.A., Obbard, M.E., and B. Malloch, Eds. (Ontario Trappers Association, North Bay, ON), pp. 656-668.

Long, C.A. 1973. Taxidea taxus. Mammalian Species 26, 1-4.

Long, C.A., and C.A. Killingley. 1983. The Badgers of the World. (Charles C. Thomas Publishing, Springfield, IL).

Lotze, J., and S. Anderson. 1970. "Procyon lotor,” Mammalian Species 119, 1-8.

MacNally, R.C., and J.M. Doolan. 1986. "An empirical approach to guild structure: habitat relationships in nine species of eastern-Australian cicadas," Oikos 47, 33-46.

Madson, J. 1990. “On the Osage,” Nature Conservancy 40, 7-15.

Martin, A.C., H.S. Zim, and A.L. Nelson. 1951. American Wildlife and Plants (McGraw-Hill Book Company, New York).

McMillan, B.R., and Kaufman, D.W. 1994. "Differences in use of interspersed woodland and grassland by small mammals in Northeastern Kansas," Prairie Naturalist 26, 107-116.

McMillan, B.R., D.W. Kaufman, G.A. Gaufman, and R.S. Matlack. 1997. "Mammals of the Konza Prairie: new observations and an updated species list," Prairie Naturalist 29, 263-272.

Mech, L.D. 1984. "Predator and predation," in White-tailed Deer: Ecology and Management, L.K. Halls, Ed. (Stackpole Books, Harrisburg, PA), pp 184-200.

Myers, P., C.S. Parr, R. Espinosa, and T. Jones, Eds. 2000. The animal diversity web. http://animaldiversity.ummz.umich.edu/

Nature Conservancy. 1996. Animals of the Tallgrass Prairie Preserve. Unpublished data.

Oklahoma Natural Heritage Inventory (ONHI). 1993. Part II. Species Inventory for Significant Species at the Tallgrass Prairie Preserve (Oklahoma Biological Survey, Norman, OK).

Payne, T, and W. Caire. 1999. "Species diversity of small mammals in the Tallgrass Prairie Preserve, Osage County, Oklahoma," in Proceedings of the Oklahoma Academy of Science 79, 51-59.

Palmer, M. 2000. Plant Species List of the Tallgrass Prairie Preserve, Oklahoma (Oklahoma State University, Tulsa, OK). Unpublished data.

Pearse, V., J. Pearse, M. Buchsbaum, and R. Buchsbaum. 1987. Living Invertebrates (Blackwell Scientific Publications, Palo Alto, CA).

Peterson, R.T. 1980. Peterson Field Guides - Eastern Birds, 4th ed. (Houghton Mifflin Co., Boston).

Pimm, S.L. 1982. Food webs (Chapman and Hall, London).

Pimm, S.L., J.H. Lawton, and J.E. Cohen. 1991. "Food web patterns and their consequences," Nature 350, 669-674. 
Pinowski, B.C. 1974. A comparative study of the behavioral and breeding ecology of the eastern bluebird (Sialia sialis), Wayne State University, Detroit, MI (Dissertation).

Pinowski, B.C. 1979. "Foraging ecology and habitat utilization in the genus Sialia," in The Role of Insectivorous Birds in Forest Ecosystems: Proceedings of a Symposium, Nacogdoches, TX, Dickson, J.G., et al., Eds. (Academic Press, Inc., New York), July 13-14, 1978, pp. 165-190.

Porter, D.K., M.A. Strong, J.B. Giezentanner, and R.A. Ryder. 1975. "Nest ecology productivity and growth of the loggerhead shrike on the short grass prairie," Southwestern Naturalist 19, 429-436.

Preston-Mafham, R.A. and K.G. 1993. The Encyclopedia of Land Invertebrate Behaviour (MIT Press, Cambridge, MA).

Risser, P.G., E.C. Birney, H.D. Blocker, S.W. May, W.J. Parton, and J.A. Wiens. 1981. The true prairie ecosystem (Hutchinson Ross Publishing Company, Stroudsburg, PA).

Robinson, S., Ed. 2000. Illinois Birds. Illinois Natural Resources Information Network. http://www.inhs.uiuc.edu/chf/pub/ifwis/birds/

Root, R.B. 1967. "The niche exploitation pattern of the blue-gray gnatcatcher," Ecological Monographs 37, 317-350.

Rossi, J.V. 1990. "Notes on the husbandry of small North American snakes," Gainesville Herpetological Society News 7(4), 10-13.

Rotenberry, J.T., and J.A. Wiens. 1980. "Habitat structure, patchiness, and avian communities in North American steppe vegetation: a multivariate analysis," Ecology 63, 952-961.

Rue, L.L. 1965. Cottontail (Thomas Y. Crowell, New York).

Schoener, T.W. 1986. "Overview: kinds of ecological communities - ecology becomes pluralistic," in Community Ecology, J. Diamond and T.J. Case, Eds. (Harper and Row, New York, NY).

Schoener, T.W. 1989. "Food webs from the small to the large," Ecology 70, 1559-1589.

Seastedt, T.R. 1984. "Belowground macroarthropods of annually burned and unburned tallgrass prairie," American Midland Naturalist 111, 405-408.

Simberloff, D., and T. Dayan. 1991. "The guild concept and the structure of ecological communities," Annual Review of Ecological Systematics 22, 115-143.

Smith, R.A., and E.L. Hanebrink. 1982. "Analysis of regurgitated short-eared owl (Asio flammeus) pellets from the Roth Prairie, Arkansas County, Arkansas," Arkansas Academy of Science Proceedings 36, 106-108.

Solow, A.R., and A.R. Beet. 1998. "On lumping species in food webs," Ecology 79, 2013-2018.

Suter, G.W. 1993. Ecological Risk Assessment (Lewis Publishers, Boca Raton, FL).

Timm, R.L. and G. Pisani. 2000. Mammals of Kansas. http://www.ukans.edu/ mammals/index.html 
Toland, B.R. 1990. "Nesting ecology of red-tailed hawks in central Missouri," Transactions of the Missouri Academy of Science 24, 1-16.

Trapp, G.R., and D.L. Hallberg. 1975. "Ecology of the gray fox (Urocyon cinereoargenteus): a review," in The Wild Canids: Their Systematics, Behavioral Ecology and Evolution, M.W. Fox, Ed. (Can Nostrand Reinhold, NY), pp. 164-178.

Van Vuren, D., and M.P. Bray. 1983. "Diets of bison and cattle on a seeded range in southern Utah,” Journal of Range Management 36, 499-500.

Van Vuren, D. 1984. "Summer diets of bison and cattle in southern Utah," Journal of Range Management 37, 260-261.

Vitt, L.J. and W.E. Cooper, Jr. 1986. "Foraging and diet of a diurnal predator Eumeces laticeps feeding on hidden prey," Journal of Herpetology 20, 408-415.

Vorhies, C.T., and W.P. Taylor. 1933. The Life Histories and Ecology of Jack Rabbits, Lepus alleni and Lepus californicus ssp., in Relation to Grazing in Arizona, University of Arizona, Agricultural Experiment Station, Tucson, AZ, Technical Bulletin No. 49.

Weigl, P.D., M.A. Steele, L.J. Sherman, and J.C. Ha. 1989. The Ecology of the Fox Squirrel (Sciurus niger) in North Carolina: Implications for Survival in the Southeast, Tall Timbers Research Station, Tallahassee, FL, Bulletin No. 24.

Whitaker, J.O. 1980. National Audubon Society Field Guide to North American Mammals (Alfred A. Knopf, Inc., New York).

Williams, R.J. and N.D. Martinez. 2000. "Simple rules yield complex food webs," Nature 404, $180-183$.

Wilson, J.B. 1999. "Guilds, functional types and ecological groups,” Oikos 86, 507-522.

Zimmerman, J.L. 1993. The Birds of Konza: the Avian Ecology of the Tallgrass Prairie (University of Kansas Press, Lawrence, KS). 


\section{Figures}


(a) Aboveground Invertebrates

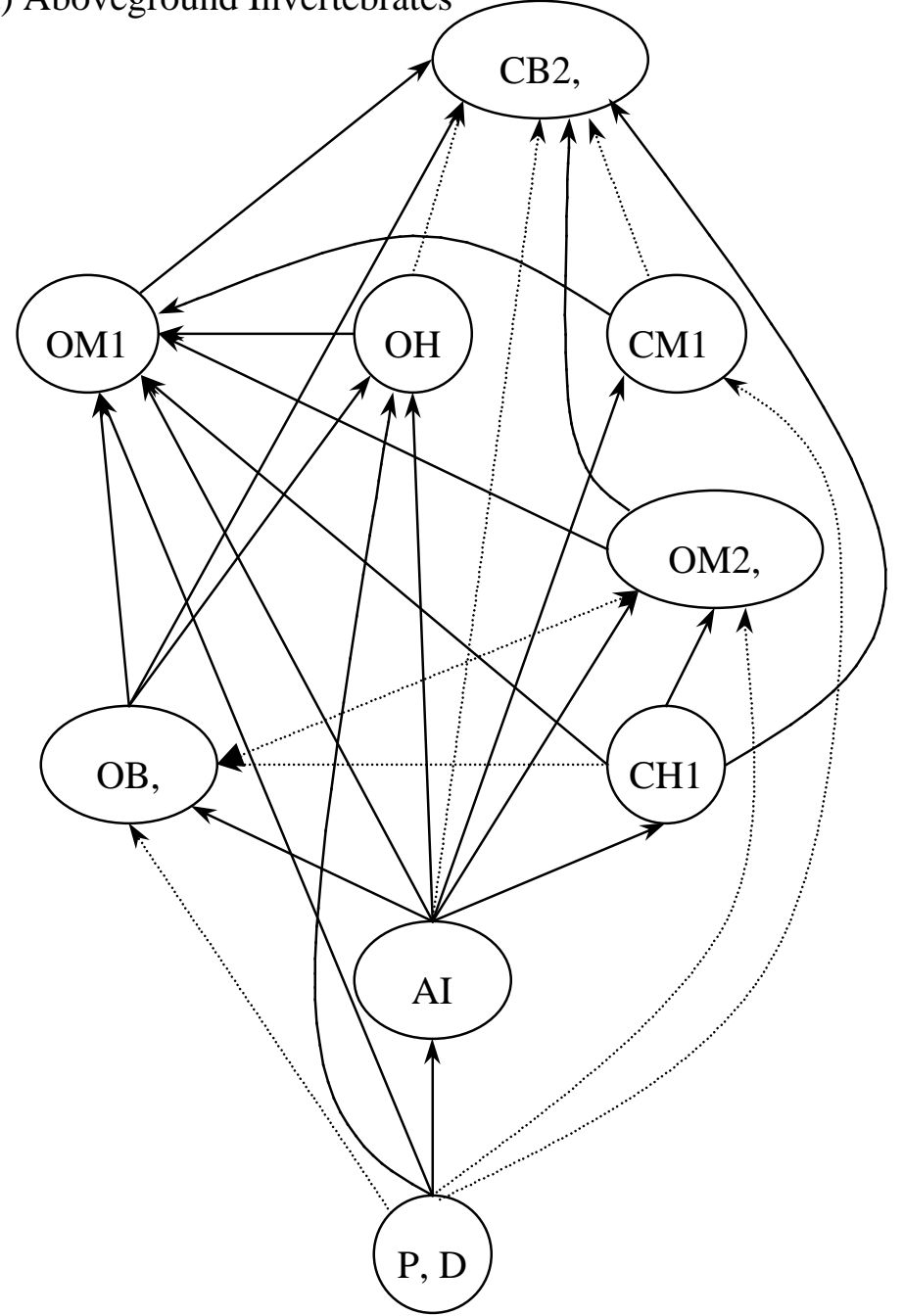

(b) Belowground Invertebrates

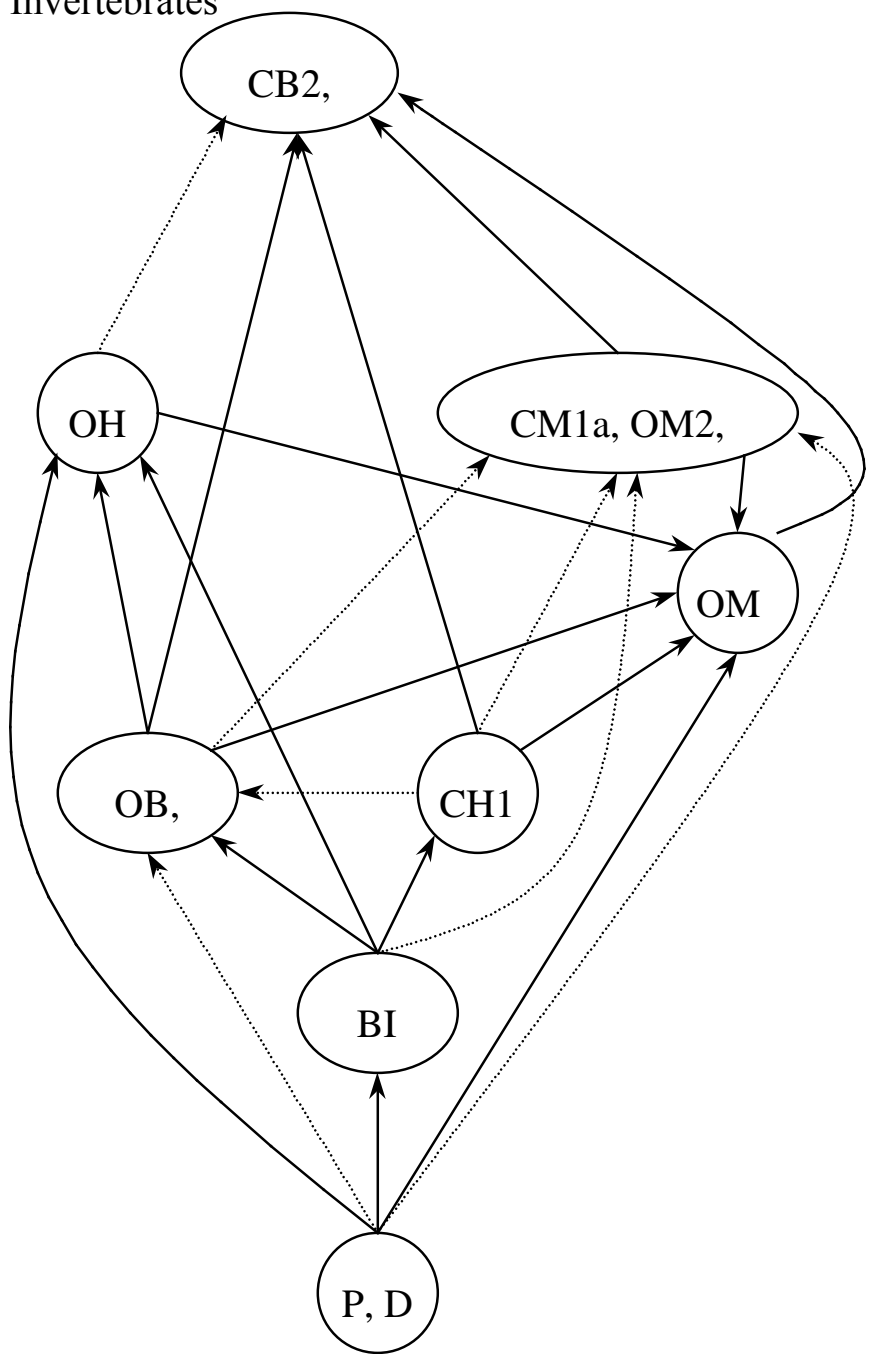

Figure 1. Source food webs at the Tallgrass Prairie Preserve, OK. Each figure begins with a guild that feeds on plants, and indicates the guilds which feed on it, their predators, and so on up the trophic system. Arrows move in the direction of energy flow (i.e., from prey to predator). For simplicity, certain guilds have been grouped together. A dashed line indicates that only one of the predator guilds applies. Looping (i.e., predation upon members of the same guild) has been omitted. It should be noted that, with the exception of the base plant eating guild in each figure, the depictions of prey for each guild may not be exhaustive (e.g., Figure 1a does not show all of the prey species that OM1 feeds upon). See page 2 of this figure for explanations of guild abbreviations. 
(c) Large Herbivorous Mammals

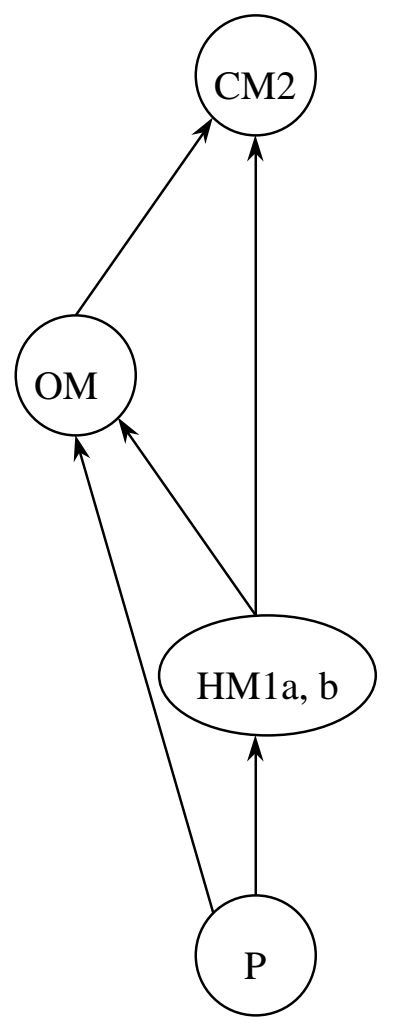

(d) Small Herbivorous Mammals

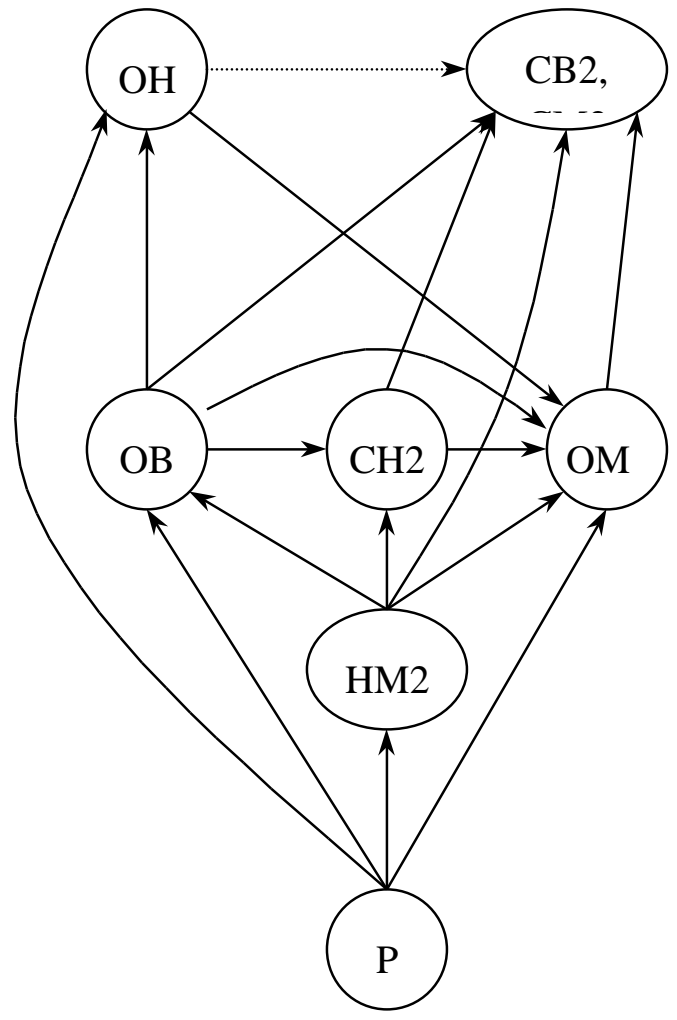

\begin{tabular}{|cl||}
\hline \hline Key to Alpha Guilds: \\
P & Plants and Fungi \\
D & Detritus and Carrion \\
AI & Aboveground Invertebrates \\
BI & Belowground Invertebrates \\
HM1a & Herbivorous Mammals - grazers \\
HM1b & Herbivorous Mammals - browsers \\
HM2 & Small Herbivorous Mammals \\
HB & Herbivorous Birds \\
OM1 & Large Omnivorous Mammals \\
OM2 & Small Omnivorous Mammals \\
OB & Omnivorous Birds \\
OH & Omnivorous Herptiles \\
CH1 & Invertivorous Herptiles \\
CH2 & Other Carnivorous Herptiles \\
CB1 & Invertivorous Birds \\
CB2 & Raptors \\
CM1a & Fossorial Invertivorous Mammals \\
CM1b & Other Invertivorous Mammals \\
CM2 & Large Carnivorous Mammals \\
\hline
\end{tabular}

Figure 1. Source food webs at the Tallgrass Prairie Preserve, OK (Cont.). 


\section{Tables}


Table 1. Typical plant species of the Tallgrass Prairie Preserve, OK. Species are divided on the basis of habitat.

\begin{tabular}{|c|c|c|}
\hline Common name & Scientific name & Source $^{a}$ \\
\hline \multicolumn{3}{|l|}{ Deciduous Riparian Guild } \\
\hline American bladdernut & Staphylea trifolia & 1,3 \\
\hline ash & Fraxinus pennsylvanica & 1,3 \\
\hline blackhaw & Viburnum rufidulum & 1,3 \\
\hline bur oak & Quercus macrocarpa & 1,3 \\
\hline buttonbush & Cephalanthus occidentalis & 1,3 \\
\hline cittamwood & Bumelia lanuginosa & 1,3 \\
\hline coral berry & Symphoricarpos orbiculatus & 1,3 \\
\hline dwarf chinquapin oak & Quercus prinoides & 1,3 \\
\hline eastern redbud & Cercis canadensis & 1,3 \\
\hline hickory & Carya cordiformis & 1,3 \\
\hline osage orange & Maclura pomifera & 1,3 \\
\hline roughleaf dogwood & Cornus drummondii & 1,3 \\
\hline shumard oak & Quercus shumardii & 1,3 \\
\hline slippery elm & Ulmus rubra & 1,3 \\
\hline sugarberry & Celic occidentalis & 1,3 \\
\hline sycamore & Platanus occidentalis & 1,3 \\
\hline willow & Salix nigra & 1,3 \\
\hline poison ivy & Toxicodendron radicans & 1,3 \\
\hline Virginia creeper & Parthenocissus quinquefolia & 1,3 \\
\hline \multicolumn{3}{|l|}{ Grassy Riparian Guild } \\
\hline goldenrod & Solidago spp. & 1,3 \\
\hline white sweet clover & Melilotus alba & 1,3 \\
\hline yellow sweet clover & Melilotus officinalis & 1,3 \\
\hline big bluestem & Andropogon gerardii & $1,2,3$ \\
\hline Canada wild rye & Elymus canadensis & 1,3 \\
\hline eastern gama grass & Tripsacum dactyloides & 1,3 \\
\hline Indian grass & Sorghastrum nutans & $1,2,3$ \\
\hline little bluestem & Schizachyrium scoparium & $1,2,3$ \\
\hline rush & Juncus spp. & 1,3 \\
\hline
\end{tabular}


Table 1. Typical plant species of the Tallgrass Prairie Preserve, OK (Cont.).

\begin{tabular}{|c|c|c|}
\hline Common name & Scientific name & Source ${ }^{a}$ \\
\hline \multicolumn{3}{|c|}{ Grassy Riparian Guild (cont.) } \\
\hline switchgrass & Panicum virgatum & $1,2,3$ \\
\hline tar dropseed & Sporobolus asper & $1,2,3$ \\
\hline Virginia wild rye & Elymus virginicus & 1,3 \\
\hline \multicolumn{3}{|l|}{ Prairie Guild } \\
\hline gaura & Gaura lindheimeri & 1,3 \\
\hline yarrow & Achillea millefolium & 1,3 \\
\hline big bluestem & Andropogon gerardii & $1,2,3$ \\
\hline Canada wild rye & Elymus canadensis & 1,3 \\
\hline eastern gama grass & Tripsacum dactyloides & 1,3 \\
\hline Indian grass & Sorghastrum nutans & $1,2,3$ \\
\hline little bluestem & Schizachyrium scoparium & $1,2,3$ \\
\hline switchgrass & Panicum virgatum & $1,2,3$ \\
\hline tar dropseed & Sporobolus asper & $1,2,3$ \\
\hline Virginia wild rye & Elymus virginicus & 1,3 \\
\hline green briar & Smilax spp. & 1,3 \\
\hline \multicolumn{3}{|c|}{ Upland Deciduous Forest Guild } \\
\hline blackjack oak & Quercus marilandica & 1,3 \\
\hline coral berry & Symphoricarpos orbiculatus & 1,3 \\
\hline dwarf chinquapin oak & Quercus prinoides & 1,3 \\
\hline eastern redbud & Cercis canadensis & 1,3 \\
\hline post oak & Quercus stellata & 1,3 \\
\hline poison ivy & Toxicodendron radicans & 1,3 \\
\hline Virginia creeper & Parthenocissus quinquefolia & 1,3 \\
\hline \multicolumn{3}{|l|}{ Rocky Outcrop Guild } \\
\hline western ragweed & Ambrosia psilostachya & $1,2,3$ \\
\hline yarrow & Achillea millefolium & 1,3 \\
\hline Canada wild rye & Elymus canadensis & 1,3 \\
\hline little bluestem & Schizachyrium scoparium & $1,2,3$ \\
\hline peppergrass & Lepidium virginicum & 1,3 \\
\hline three-awn & Aristida spp. & 1,3 \\
\hline Virginia wild rye & Elymus virginicus & 1,3 \\
\hline
\end{tabular}


Table 1. Typical plant species of the Tallgrass Prairie Preserve, OK (Cont.).

\begin{tabular}{lll}
\hline \hline Common name & Scientific name & Source $^{\mathrm{a}}$ \\
\hline Rocky Outcrop Guild (cont.) & & \\
blackjack oak & Quercus marilandica & 1,3 \\
hackberry & Celtis reticulata & 1,3 \\
post oak & Quercus stellata & 1,3 \\
blackberry & Rubus spp. & 1,3 \\
Disturbed Area Guild & & \\
broomweed & Gutierrezia dracunculoides & $1,2,3$ \\
gaura & Gaura lindheimeri & 1,3 \\
goldenrod & Solidago spp. & 1,3 \\
lamb's quarter & Chenopodium album & 1,3 \\
nightshade & Solanum spp. & 1,3 \\
western ragweed & Ambrosia psilostachya & $1,2,3$ \\
white sweet clover & Melilotus alba & 1,3 \\
yellow sweet clover & Melilotus officinalis & 1,3 \\
little bluestem & Schizachyrium scoparium & $1,2,3$ \\
\hline \hline
\end{tabular}

a Sources: 1. Oklahoma Natural Heritage Inventory, 1993; 2. Coppedge and Shaw, 1998; Payne and Caire, 1999. 
Table 2. Alpha animal guilds of the Tallgrass Prairie Preserve, OK. Species are divided into guilds on the basis of trophic level (i.e., herbivore, omnivore, carnivore) and taxonomy (i.e., mammal, herptile, bird).

\begin{tabular}{lll}
\hline \hline Common name & Scientific name & Source $^{\mathrm{a}}$ \\
\hline
\end{tabular}

Herbivorous Mammal Guild 1a, large grazers

$\begin{array}{llr}\text { Bison } & \text { Bison bison 2, 3, } 5\end{array}$

Cow Bos spp.

Herbivorous Mammal Guild 1b, browsers

White tailed Deer

Odocoileus virginianus

$1,2,4,5$

Herbivorous Mammal Guild 2, smaller herbivores

$\begin{array}{llc}\text { Beaver } & \text { Castor canadensis } & 1,2,4 \\ \text { Black-tailed Jack Rabbit } & \text { Lepus californicus } & 1,2,4 \\ \text { Eastern Cottontail } & \text { Sylvilagus floridanus } & 1,4,5 \\ \text { Eastern Woodrat } & \text { Neotoma floridana } & 1,2,4,5 \\ \text { Hispid Pocket Mouse } & \text { Chaetodipus hispidus } & 1,2,5 \\ \text { House Mouse } & \text { Mus musculus } & 1,2,4 \\ \text { Prairie Vole } & \text { Microtus ochrogaster } & 1,2,5 \\ \text { Woodchuck } & \text { Marmota monax } & 2,4,5 \\ \text { Woodland Vole } & \text { Microtus pinetorum } & 1,2,4,5\end{array}$

Omnivorous Mammal Guild 1, larger omnivores

$\begin{array}{llc}\text { Coyote } & \text { Canis latrans } & \mathbf{1}, 2,5,7 \\ \text { Gray Fox } & \text { Urocyon cinereoargenteus } & \mathbf{2 , 4}, 5 \\ \text { Virginia opossum } & \text { Didelphis virginiana } & 1,2,5 \\ \text { Nine-banded Armadillo } & \text { Dasypus novemcinctus } & \mathbf{1}, 4,5 \\ \text { Raccoon } & \text { Procyon lotor } & \mathbf{1}, 2,5 \\ \text { Striped Skunk } & \text { Mephitis mephitis } & \mathbf{1 , 2 , 5}\end{array}$

Omnivorous Mammal Guild 2, smaller omnivores

13-lined Ground Squirrel

Cotton Mouse

Deer Mouse

Eastern Harvest Mouse

Fox Squirrel

Fulvous Harvest Mouse

Muskrat

Plains Harvest Mouse
Spermophilus tridecimlineatus

Peromyscus gossypinus

Peromyscus maniculatus

Reithrodontomys humulis

Sciurus niger

Reithrodontomys fulvescens

Ondatra zibethicus

Reithrodontomys montanus
2,5

$1,2,6$

$1,2,4,5$

$1,2,6$

$1,4,5$

$1,2,5,6$

2, 5

$1,2,5$ 
Table 2. Alpha animal guilds of the Tallgrass Prairie Preserve, OK. (Cont.).

\begin{tabular}{lll}
\hline \hline Common name & Scientific name & Source $^{\text {a }}$ \\
\hline Omnivorous Mammal Guild 2, smaller & omnivores (cont.) & \\
White-footed Mouse & Peromyscus leucopus & $\mathbf{1}, 2,4,5,6$ \\
Western Harvest Mouse & Reithrodontomys megalotis & $1,2,5$ \\
Hispid Cotton Rat & Sigmodon hispidus & $\mathbf{1 , 2 , 5 , 1 3}$
\end{tabular}

Carnivorous Mammal Guild 1a, fossorial invertivores

$\begin{array}{llr}\text { Eastern Mole } & \text { Scalopus aquaticus } & \mathbf{1}, 2,4,5 \\ \text { Least Shrew } & \text { Cryptotis parva } & \mathbf{1}, 2,4,5\end{array}$

Carnivorous Mammal Guild 1b, flying invertivores
Evening Bat
Nycticeius humeralis
1,6
Red Bat
Lasiurus borealis
$1,2,5,6$

Carnivorous Mammal Guild 2, large predators

$\begin{array}{llc}\text { Badger } & \text { Taxidea taxus } & 1,2,4,5 \\ \text { Bobcat } & \text { Felis rufus } & 1,2,5 \\ \text { Mink } & \text { Mustela vison } & 2,4,5 \\ \text { Mountain Lion } & \text { Felis concolor } & 1,2,4,5\end{array}$

Omnivorous Herptile Guild

Ornate Box Turtle

Terrapene ornata

2,8

Three-toed Box Turtle

Terrapene carolina

2,8

Carnivorous Herptile Guild 1, invertivores

$\begin{array}{llc}\text { Broadhead Skink } & \text { Eumeces laticeps } & 2,8,15 \\ \text { Brown Snake } & \text { Storeria dekayi } & 2,8 \\ \text { Cope's Tree Frog } & \text { Hyla chrysoscelis } & 2,8 \\ \text { Dwarf American Toad } & \text { Bufo americanus } & 2,8 \\ \text { Five-lined Skink } & \text { Eumeces fasciatus } & 2,8 \\ \text { Flathead Snake } & \text { Tantilla gracilis } & 2,8 \\ \text { Gray Tree Frog } & \text { Hyla versicolor } & 2,8 \\ \text { Great Plains Narrowmouth Toad } & \text { Gastrophryne olivacea } & 2,11 \\ \text { Great Plains Skink } & \text { Eumeces obsoletus } & 2,11 \\ \text { Ground Skink } & \text { Scincella lateralis } & 2,11 \\ \text { Ground Snake } & \text { Sonora semiannulata } & 2,14 \\ \text { Lined Snake } & \text { Tropidoclonium lineatum } & 2,8,13 \\ \text { Plains Leopard Frog } & \text { Rana blairi } & 2,8\end{array}$


Table 2. Alpha animal guilds of the Tallgrass Prairie Preserve, OK. (Cont.).

\begin{tabular}{lll}
\hline \hline Common name & Scientific name & Source \\
\hline Carnivorous Herptile Guild 1, invertivores (cont.) & \\
\hline \multicolumn{2}{c}{ Rough Earth Snake } & Virginia striatula \\
Rough Green Snake & Opheodrys aestivus & 2,16 \\
Southern Leopard Frog & Rana utricularia & 2,8 \\
Southern Prairie Skink & Eumeces septentrionalis & 2,8 \\
Strecker's Chorus Frog & Pseudacris streckeri & 2,11 \\
Texas Horned Lizard & Phrynosoma cornutum & 2,8 \\
Western Chorus Frog & Pseudacris triseriata & 2,11 \\
Woodhouse's Toad & Bufo woodhousei & 2,8 \\
\end{tabular}

Carnivorous Herptile Guild 2, other carnivores

Black Ratsnake
Broad-banded Copperhead
Bull Frog
Bullsnake
Central Plains Milk Snake
Coachwhip
Common Garter Snake
Crawfish Frog
Eastern Collared Lizard
Eastern Hognose Snake
Great Plains Ratsnake
Massasauga
Prairie Kingsnake
Ringneck Snake
Speckled Kingsnake
Timber Rattlesnake
Western Glass Lizard
Western Ribbon Snake
Yellowbelly Racer

Elaphe obseleta

2,9

Agkistrodon contortrix

2,8

Rana catesbeiana

2,8

Pituophis melanoleucus

$2,8,9$

Lampropeltis triangulum

$2,8,9$

Masticophis flagellum

2,8

Thamnophis sirtalis

2,8

Rana areolata

2,8

Crotaphytus collaris

$2,4,8$

Heterodon platyrhinos

2,8

Elaphe guttata

$2,8,9$

Sistrurus catenatus

2,8

Lampropeltis calligaster

$2,8,9$

Diadophis punctatus

$2,8,10$

Lampropeltis getulus

$2,8,9$

Crotalus horridus

2,8

Ophisaurus attenuatus

2,8

Thamnophis proximus

2,8

Coluber constrictor

$2,8,9$ 
Table 2. Alpha animal guilds of the Tallgrass Prairie Preserve, OK. (Cont.).

\begin{tabular}{|c|c|c|}
\hline Common name & Scientific name & Source ${ }^{a}$ \\
\hline \multicolumn{3}{|l|}{ Omnivorous Bird Guild } \\
\hline Blue jay & Cyanocitta cristata & $1,2,12$ \\
\hline Bluebird, mountain & Sialia currucoides & 1,12 \\
\hline Bobwhite & Colinus virginianus & $1,2,12$ \\
\hline Brown thrasher & Toxostoma rufum & $1,2,12$ \\
\hline Bunting, indigo & Passerina cyanea & $1,2,12$ \\
\hline Bunting, painted & Passerina ciris & 2,12 \\
\hline Canada goose & Branta canadensis & $1,2,4$ \\
\hline Cardinal & Cardinalis cardinalis & $1,2,12$ \\
\hline Catbird & Dumetella carolinensis & 2,12 \\
\hline Chickadee, Carolina & Parus carolinensis & $1,2,12$ \\
\hline Coot, American & Fulica americana & 2,12 \\
\hline Cowbird, brown-headed & Molothrus ater & $1,2,12$ \\
\hline Crow, American & Corvus brachyrhynchos & $1,2,12$ \\
\hline Crow, fish & Corvus ossifragus & 2,12 \\
\hline Dickcissel & Spiza americana & $1,2,12$ \\
\hline Dove, mourning & Zenaida macroura & $1,2,4$ \\
\hline Dove, rock & Columba livia & 2,12 \\
\hline Duck, ring-necked & Aythya collaris & $1,2,12$ \\
\hline Gadwall & Anas strepera & 2,12 \\
\hline Goldfinch, American & Carduelis tristis & 2,12 \\
\hline Grackle, common & Quiscalus quiscula & $1,2,17$ \\
\hline Grackle, great-tailed & Quiscalus mexicanus & 2,12 \\
\hline Great prairie chicken & Tympanuchus cupido & $1,2,17$ \\
\hline Grosbeak, blue & Guiraca caerulea & $1,2,12$ \\
\hline Gull, Franklin's & Larus pipixcan & 2,12 \\
\hline Gull, ring-billed & Larus delawarensis & 2,12 \\
\hline Horned lark & Eremophila alpestris & $1,2,12$ \\
\hline Hummingbird, ruby-throated & Arcjilochus colubris & 2,12 \\
\hline Junco, dark-eyed & Junco hyemalis & 2,12 \\
\hline Mallard & Anas platyrhynchos & 2,12 \\
\hline Meadowlark, eastern & Sturnella magna & $1,2,12$ \\
\hline Mockingbird & Mimus polyglottos & $1,2,12$ \\
\hline
\end{tabular}


Table 2. Alpha animal guilds of the Tallgrass Prairie Preserve, OK. (Cont.).

\begin{tabular}{|c|c|c|}
\hline Common name & Scientific name & Source \\
\hline \multicolumn{3}{|l|}{ Omnivorous Bird Guild (cont.) } \\
\hline Nuthatch, whitebreasted & Sitta carolenensis & $1,2,12$ \\
\hline Oriole, Northern & Icterus galbula & 2,12 \\
\hline Oriole, orchard & Icterus spurius & $1,2,12$ \\
\hline Pheasant, ring-necked & Phasianus colchicus & 2,12 \\
\hline Pintail, northern & Anas acuta & 2,12 \\
\hline Plover, lesser golden & Pluvialis squatarola & 2,12 \\
\hline Rail, king & Rallus elegans & 2,12 \\
\hline Redhead & Aythya americana & $1,2,12$ \\
\hline Robin & Turdus migratorius & $1,2,12$ \\
\hline Scaup, lesser & Aythya affinis & 2,12 \\
\hline Shoveler, Northern & Anas clypeata & 2,12 \\
\hline Sora & Porzana carolina & 2,12 \\
\hline Sparrow, American tree & Spizella arborea & 2,12 \\
\hline Sparrow, chipping & Spizella passerina & $1,2,12$ \\
\hline Sparrow, field & Spizella pusilla & $1,2,12$ \\
\hline Sparrow, grasshopper & Ammodramus savannarum & $1,2,12$ \\
\hline Sparrow, Harris' & Zonotrichia querula & 2,12 \\
\hline Sparrow, house & Passer domesticus & $1,2,12$ \\
\hline Sparrow, lark & Chondestes grammacus & $1,2,12$ \\
\hline Sparrow, Lincoln's & Melospiza lincolnii & 2,12 \\
\hline Sparrow, savannah & Passerculus sandwichensis & $1,2,12$ \\
\hline Sparrow, song & Melospiza melodia & 2,12 \\
\hline Sparrow, vesper & Pooecetes gramineus & $1,2,12$ \\
\hline Sparrow, white-crowned & Zonotrichia leucophrys & 2,12 \\
\hline Sparrow, white-throated & Zonotrichia albicollis & 2,12 \\
\hline Starling & Sturnus vulgaris & $1,2,12$ \\
\hline Summer tanager & Piranga rubra & $1,2,12$ \\
\hline Thrush, wood & Hylocichla mustelina & 2,12 \\
\hline Towhee, rufous-sided & Pipilo erythrophthalmus & 2,12 \\
\hline Tufted titmouse & Parus inornatus & $1,2,12$ \\
\hline Turkey & Meleagris gallopavo & $1,2,12$ \\
\hline Warbler, yellow-rumped & Dendroica coronata & 2,4 \\
\hline
\end{tabular}


Table 2. Alpha animal guilds of the Tallgrass Prairie Preserve, OK. (Cont.).

\begin{tabular}{|c|c|c|}
\hline Common name & Scientific name & Source \\
\hline \multicolumn{3}{|l|}{ Omnivorous Bird Guild (cont.) } \\
\hline Waterthrush, Louisiana & Seiurus motacilla & $1,2,12$ \\
\hline Waxwing, cedar & Bombycilla garrulus & 2,12 \\
\hline Widgeon, American & Anas americana & 2,12 \\
\hline Woodpecker, pileated & Dryocopus pileatus & $1,2,4$ \\
\hline Woodpecker, red-headed & Melanerpes erythrocephalus & $1,2,4$ \\
\hline \multicolumn{3}{|c|}{ Carnivorous Bird Guild 1, invertivores } \\
\hline Bluebird, eastern & Sialia sialis & $1,2,12$ \\
\hline Chimney swift & Chaetura pelagica & $1,2,12$ \\
\hline Chuck-will's-widow & Caprimulgus carolinensis & $1,2,12$ \\
\hline Creeper, brown & Certhia familiaris & 2,12 \\
\hline Dowitcher, long-billed & Limnodromus griseus & 2,12 \\
\hline Egret, cattle & Bubulcus ibis & $1,2,12$ \\
\hline Flycatcher, Acadian & Empidomax virescens & 2,12 \\
\hline Flycatcher, alder & Empidomax alnorum & 2,12 \\
\hline Flycatcher, great crested & Myiarchus crinitus & $1,2,12$ \\
\hline Flycatcher, least & Empidomax minimus & 2,12 \\
\hline Flycatcher, scissor-tailed & Tyrannus forficatus & $1,2,12$ \\
\hline Flycatcher, willow & Empidomax traillii & 2,12 \\
\hline Gnatcatcher, blue-gray & Polioptila caerulea & $1,2,12$ \\
\hline Godwit, Hudsonian & Limosa haemastica & 2,12 \\
\hline Killdeer & Charadrius vociferous & $1,2,12$ \\
\hline Kingbird, eastern & Tyrannus tyrannus & $1,2,12$ \\
\hline Kingbird, western & Tyrannus verticalis & $1,2,12$ \\
\hline Kinglet, golden-crowned & Regulus satrapa & 2,12 \\
\hline Loggerhead shrike & Lanius ludovicianus & $1,2,12$ \\
\hline Nighthawk & Chordeiles minor & $1,2,12$ \\
\hline Northern flicker & Colaptes auratus & $1,2,12$ \\
\hline Phoebe, eastern & Savornis phoebe & 1,12 \\
\hline Poorwill & Phalaenoptilus nuttallii & 2,12 \\
\hline Purple martin & Progne subis & $1,2,12$ \\
\hline Sandpiper, semipalmated & Calidris pusilla & 1,12 \\
\hline Sandpiper, solitary & Tringa solitaria & $1,2,12$ \\
\hline
\end{tabular}


Table 2. Alpha animal guilds of the Tallgrass Prairie Preserve, OK. (Cont.).

\begin{tabular}{|c|c|c|}
\hline Common name & Scientific name & Source $^{\mathrm{a}}$ \\
\hline \multicolumn{3}{|c|}{ Carnivorous Bird Guild 1, invertivores (cont.) } \\
\hline Sandpiper, upland & Bartramia longicauda & $1,2,12$ \\
\hline Snipe & Gallinago gallinago & $1,2,12$ \\
\hline Swallow, bank & Riparia riparia & 1,12 \\
\hline Swallow, barn & Hirundo rustica & $1,2,12$ \\
\hline Swallow, cliff & Hirundo pyrrhonata & $1,2,12$ \\
\hline Swallow, rough-winged & Stelgidopteryx serripennis & $1,2,12$ \\
\hline Vireo, Bell's & Vireo bellii & 2,12 \\
\hline Vireo, red-eyed & Vireo olivaceous & 2,12 \\
\hline Vireo, yellow-throated & Vireo flavifrons & 1,12 \\
\hline Warbler, black and white & Mniotilta varia & $1,2,12$ \\
\hline Warbler, Cape May & Dendroica tigrina & 2,12 \\
\hline Warbler, Kentucky & Oporornis formosus & 2,12 \\
\hline Warbler, Northern parula & Parula americana & 2,12 \\
\hline Warbler, yellow & Dendroica petechia & 2,12 \\
\hline Whip-poor-will & Caprimulgus vociferus & 2,12 \\
\hline Woodpecker, downy & Picoides pubescens & $1,2,12$ \\
\hline Woodpecker, hairy & Picoides villosus & 2,12 \\
\hline Woodpecker, red-bellied & Melanerpes carolinus & $1,2,12$ \\
\hline Wood-pewee, eastern & Contopus virens & $1,2,12$ \\
\hline Wren, Bewick's & Thryomanes bewickii & $1,2,17$ \\
\hline Wren, Carolina & Thryothorus ludovicianus & $1,2,12$ \\
\hline Yellow-billed cuckoo & Coccyzus americanus & $1,2,12$ \\
\hline Yellowlegs, greater & Tringa melanoleuca & 2,12 \\
\hline Yellowlegs, lesser & Tringa flavipes & 2,12 \\
\hline Yellowthroat, common & Geothlypis trichas & $1,2,12$ \\
\hline \multicolumn{3}{|c|}{ Carnivorous Bird Guild 2, raptors } \\
\hline Eagle, bald & Haliaeetus leucocephalus & 2,12 \\
\hline Falcon, peregrine & Falco peregrinus & 2,12 \\
\hline Harrier, northern & Circus cyaneus & $1,2,12$ \\
\hline Hawk, broad-winged & Buteo platypterus & 2,12 \\
\hline Hawk, Cooper's & Accipiter cooperii & $1,2,12$ \\
\hline Hawk, red-tailed & Buteo jamaicensus & $1,2,12$ \\
\hline
\end{tabular}


Table 2. Alpha animal guilds of the Tallgrass Prairie Preserve, OK. (Cont.).

\begin{tabular}{lll}
\hline \hline Common name & Scientific name & Source \\
\hline \multicolumn{2}{l}{ Carnivorous Bird Guild 2, raptors (cont.) } \\
\hline Hawk, rough-legged & Buteo lagopus & \\
Hawk, sharp-shinned & Accipiter striatus & 2,12 \\
Hawk, Swainson's & Buteo swainsoni & 2,12 \\
Kestrel & Falco sparverius & 2,12 \\
Kite, Mississippi & Ictinia mississippiensis & $1,2,12$ \\
Merlin & Falco columbarius & 2,12 \\
Owl, barn & Tyto alba & 2,12 \\
Owl, barred & Strix varia & 2,12 \\
Owl, burrowing & Athene cunicularia & 2,12 \\
Owl, great horned & Bubo virginianus & 2,12 \\
Owl, screech & Otus asio & $1,2,12$ \\
Owl, short-eared & Asio flammeus & 2,12 \\
Vulture, turkey & Cathartes aura & 2,12 \\
\hline a & Indicates source for both presence/absence and diet. Sources: 1. Oklahoma Natural Heritage Inventory, 1993; 2. \\
Nature Conservancy, 1996; 3. Coppedge and Shaw, 1998; 4. Myers et al., 2000; 5. Risser et al., 1981; 6. Davis and \\
Schmidly, 1994; 7. Brillhart and Kaufman, 1994; 8. INHS, 1998; 9. Cavitt, 2000; 10. Conant and Collins, 1998; 11. \\
Bockstanz and Cannatella, 2000; 12. Peterson, 1980; 13. Whitaker, 1980; 14. Cossel, 1998; 15. Vitt and Cooper, \\
1986; 16. Rossi, 1990; 17. Robinson, 2000; 18. Hamilton, 1996.
\end{tabular}


Table 3. Beta animal guilds of the Tallgrass Prairie Preserve, OK. Six guilds are delineated on the basis of habitat. Alpha Guild members within each beta guild are grouped for easy reference.

\begin{tabular}{|c|c|c|c|}
\hline Common name & Scientific name & Source $^{a}$ & $\begin{array}{l}\text { Alpha } \\
\text { guild }^{\text {b }}\end{array}$ \\
\hline \multicolumn{4}{|l|}{ Deciduous Riparian Guild } \\
\hline Flycatcher, great crested & Myiarchus crinitus & 12 & CB1 \\
\hline Flycatcher, least & Empidomax minimus & 12 & CB1 \\
\hline Gnatcatcher, blue-gray & Polioptila caerulea & 12 & CB1 \\
\hline Kinglet, golden-crowned & Regulus satrapa & 12 & CB1 \\
\hline Northern flicker & Colaptes auratus & 12 & CB1 \\
\hline Phoebe, eastern & Savornis phoebe & 12 & CB1 \\
\hline Swallow, rough-winged & Stelgidopteryx serripennis & 12 & CB1 \\
\hline Vireo, red-eyed & Vireo olivaceous & 12 & CB1 \\
\hline Warbler, black and white & Mniotilta varia & 12 & CB1 \\
\hline Warbler, Kentucky & Oporornis formosus & 12 & CB1 \\
\hline Warbler, yellow & Dendroica petechia & 12 & CB1 \\
\hline Whip-poor-will & Caprimulgus vociferus & 12 & CB1 \\
\hline Woodpecker, downy & Picoides pubescens & 12 & CB1 \\
\hline Woodpecker, hairy & Picoides villosus & 12 & CB1 \\
\hline Wood-pewee, eastern & Contopus virens & 12 & CB1 \\
\hline Wren, Carolina & Thryothorus ludovicianus & 12 & CB1 \\
\hline Yellow-billed cuckoo & Coccyzus americanus & 12 & CB1 \\
\hline Hawk, Cooper's & Accipiter cooperii & 12 & CB2 \\
\hline Hawk, red-tailed & Buteo jamaicensus & 12 & CB2 \\
\hline Hawk, sharp-shinned & Accipiter striatus & 12 & CB2 \\
\hline Owl, barred & Strix varia & 12 & CB2 \\
\hline Owl, great horned & Bubo virginianus & 12 & $\mathrm{CB} 2$ \\
\hline Owl, screech & Otus asio & 12 & CB2 \\
\hline Broadhead Skink & Eumeces laticeps & 2,7 & CH1 \\
\hline Brown Snake & Storeria dekayi & 2,7 & $\mathrm{CH} 1$ \\
\hline Cope's Tree Frog & Hyla chrysoscelis & 2,7 & $\mathrm{CH} 1$ \\
\hline Dwarf American Toad & Bufo americanus & 2,7 & $\mathrm{CH1}$ \\
\hline Five-lined Skink & Eumeces fasciatus & 2,7 & $\mathrm{CH} 1$ \\
\hline Gray Tree Frog & Hyla versicolor & 2,7 & $\mathrm{CH} 1$ \\
\hline
\end{tabular}


Table 3. Beta animal guilds of the Tallgrass Prairie Preserve, OK (Cont.)

\begin{tabular}{|c|c|c|c|}
\hline Common name & Scientific name & Source $^{a}$ & $\begin{array}{l}\text { Alpha } \\
\text { guild }^{\text {b }}\end{array}$ \\
\hline \multicolumn{4}{|l|}{ Deciduous Riparian Guild (cont.) } \\
\hline Great Plains Narrowmouth Toad & Gastrophryne olivacea & 2,8 & CH1 \\
\hline Ground Skink & Scincella lateralis & 2,7 & $\mathrm{CH1}$ \\
\hline Plains Leopard Frog & Rana blairi & 2,7 & $\mathrm{CH} 1$ \\
\hline Rough Green Snake & Opheodrys aestivus & 2,7 & CH1 \\
\hline Southern Leopard Frog & Rana utricularia & 2,7 & $\mathrm{CH1}$ \\
\hline Western Chorus Frog & Pseudacris triseriata & 2,7 & CH1 \\
\hline Bull Frog & Rana catesbeiana & 2,7 & $\mathrm{CH} 2$ \\
\hline Common Garter Snake & Thamnophis sirtalis & 2,7 & $\mathrm{CH} 2$ \\
\hline Crawfish Frog & Rana areolata & 2,7 & $\mathrm{CH} 2$ \\
\hline Eastern Hognose Snake & Heterodon platyrhinos & 2,7 & $\mathrm{CH} 2$ \\
\hline Massasauga & Sistrurus catenatus & 2,7 & $\mathrm{CH} 2$ \\
\hline Western Ribbon Snake & Thamnophis proximus & 2,7 & $\mathrm{CH} 2$ \\
\hline Eastern Mole & Scalopus aquaticus & 1,2 & CM1A \\
\hline Evening Bat & Nycticeius humeralis & 1 & CM1B \\
\hline Red Bat & Lasiurus borealis & 1,2 & CM1B \\
\hline Bobcat & Felis rufus & 1,2 & CM2 \\
\hline Mink & Mustela vison & 2,4 & CM2 \\
\hline Mountain Lion & Felis concolor & 1,2 & $\mathrm{CM} 2$ \\
\hline Bison & Bison bison & 1,2 & HM1A \\
\hline Cow & Bos spp. & 13 & HM1A \\
\hline White tailed Deer & Odocoileus virginianus & 1,2 & HM1B \\
\hline Beaver & Castor canadensis & 1,2 & HM2 \\
\hline Eastern Cottontail & Sylvilagus floridanus & 1 & HM2 \\
\hline Eastern Woodrat & Neotoma floridana & $1,2,11$ & HM2 \\
\hline Hispid Cotton Rat & Sigmodon hispidus & $1,2,11$ & HM2 \\
\hline Muskrat & Ondatra zibethicus & 2,3 & HM2 \\
\hline Prairie Vole & Microtus ochrogaster & $1,2,11$ & HM2 \\
\hline Woodchuck & Marmota monax & 2,4 & HM2 \\
\hline Blue jay & Cyanocitta cristata & 12 & OB \\
\hline Bluebird, eastern & Sialia sialis & 12 & OB \\
\hline Bobwhite & Colinus virginianus & 12 & OB \\
\hline
\end{tabular}


Table 3. Beta animal guilds of the Tallgrass Prairie Preserve, OK (Cont.)

\begin{tabular}{|c|c|c|c|}
\hline Common name & Scientific name & Source $^{\mathrm{a}}$ & $\begin{array}{l}\text { Alpha } \\
\text { guild }^{\text {b }}\end{array}$ \\
\hline \multicolumn{4}{|l|}{ Deciduous Riparian Guild (cont.) } \\
\hline Bunting, indigo & Passerina cyanea & 12 & OB \\
\hline Cardinal & Cardinalis cardinalis & 12 & OB \\
\hline Cowbird, brown-headed & Molothrus ater & 12 & OB \\
\hline Crow, american & Corvus brachyrhynchos & 12 & OB \\
\hline Duck, wood & Aix sponsa & 12 & OB \\
\hline Grackle, common & Quiscalus quiscula & 12 & OB \\
\hline Hummingbird, ruby-throated & Arcjilochus colubris & 12 & OB \\
\hline Junco, dark-eyed & Junco hyemalis & 12 & OB \\
\hline Nuthatch, whitebreasted & Sitta carolenensis & 12 & OB \\
\hline Oriole, Northern & Icterus galbula & 12 & OB \\
\hline Robin & Turdus migratorius & 12 & OB \\
\hline Sparrow, American tree & Spizella arborea & 12 & OB \\
\hline Sparrow, chipping & Spizella passerina & 12 & OB \\
\hline Sparrow, Harris' & Zonotrichia querula & 12 & OB \\
\hline Sparrow, Lincoln's & Melospiza lincolnii & 12 & OB \\
\hline Sparrow, song & Melospiza melodia & 12 & OB \\
\hline Sparrow, white-crowned & Zonotrichia leucophrys & 12 & OB \\
\hline Sparrow, white-throated & Zonotrichia albicollis & 12 & OB \\
\hline Starling & Sturnus vulgaris & 12 & OB \\
\hline Summer tanager & Piranga rubra & 12 & OB \\
\hline Thrush, wood & Hylocichla mustelina & 12 & OB \\
\hline Towhee, rufous-sided & Pipilo erythrophthalmus & 12 & OB \\
\hline Tufted titmouse & Parus inornatus & 12 & OB \\
\hline Turkey & Meleagris gallopavo & 12 & OB \\
\hline Warbler, yellow-rumped & Dendroica coronata & 12 & OB \\
\hline Waterthrush, Louisiana & Seiurus motacilla & 12 & OB \\
\hline Waxwing, cedar & Bombycilla garrulus & 12 & OB \\
\hline Woodpecker, red-bellied & Melanerpes carolinus & 12 & OB \\
\hline Woodpecker, red-headed & Melanerpes erythrocephalus & 12 & OB \\
\hline Three-toed Box Turtle & Terrapene carolina & 2,7 & $\mathrm{OH}$ \\
\hline Coyote & Canis latrans & 1,2 & OM1 \\
\hline
\end{tabular}


Table 3. Beta animal guilds of the Tallgrass Prairie Preserve, OK (Cont.)

\begin{tabular}{|c|c|c|c|}
\hline Common name & Scientific name & Source $^{a}$ & $\begin{array}{l}\text { Alpha } \\
\text { guild }^{\text {b }}\end{array}$ \\
\hline \multicolumn{4}{|l|}{ Deciduous Riparian Guild (cont.) } \\
\hline Gray Fox & Urocyon cinereoargenteus & 2,3 & OM1 \\
\hline Nine-banded Armadillo & Dasypus novemcinctus & 1 & OM1 \\
\hline Raccoon & Procyon lotor & 1,2 & OM1 \\
\hline Striped Skunk & Mephitis mephitis & 1,2 & OM1 \\
\hline Cotton Mouse & Peromyscus gossypinus & $1,2,11$ & OM2 \\
\hline Fox Squirrel & Sciurus niger & 1 & OM2 \\
\hline Fulvous Harvest Mouse & Reithrodontomys fulvescens & $1,2,11$ & OM2 \\
\hline White-footed Mouse & Peromyscus leucopus & $1,2,11$ & OM2 \\
\hline \multicolumn{4}{|l|}{ Grassy Riparian Guild } \\
\hline Brown Snake & Storeria dekayi & 2,7 & CH1 \\
\hline Dwarf American Toad & Bufo americanus & 2,7 & $\mathrm{CH} 1$ \\
\hline Great Plains Narrowmouth Toad & Gastrophryne olivacea & 2,8 & CH1 \\
\hline Plains Leopard Frog & Rana blairi & 2,7 & $\mathrm{CH} 1$ \\
\hline Southern Leopard Frog & Rana utricularia & 2,7 & $\mathrm{CH1}$ \\
\hline Western Chorus Frog & Pseudacris triseriata & 2,7 & $\mathrm{CH} 1$ \\
\hline Bull Frog & Rana catesbeiana & 2,7 & $\mathrm{CH} 2$ \\
\hline Central Plains Milk Snake & Lampropeltis triangulum & 2,7 & $\mathrm{CH} 2$ \\
\hline Crawfish Frog & Rana areolata & 2,7 & $\mathrm{CH} 2$ \\
\hline Western Ribbon Snake & Thamnophis proximus & 2,7 & $\mathrm{CH} 2$ \\
\hline Bobcat & Felis rufus & 1,2 & $\mathrm{CM} 2$ \\
\hline Mink & Mustela vison & 2,4 & $\mathrm{CM} 2$ \\
\hline Mountain Lion & Felis concolor & 1,2 & CM2 \\
\hline Bison & Bison bison & 1,2 & HM1A \\
\hline Cow & Bos spp. & 13 & HM1A \\
\hline White tailed Deer & Odocoileus virginianus & 1,2 & HM1B \\
\hline Beaver & Castor canadensis & 1,2 & HM2 \\
\hline Elliot's Short-tailed shrew & Blarina hylophaga & $1,2,11$ & HM2 \\
\hline Hispid Cotton Rat & Sigmodon hispidus & $1,2,11$ & HM2 \\
\hline Muskrat & Ondatra zibethicus & 2,3 & HM2 \\
\hline Prairie Vole & Microtus ochrogaster & $1,2,11$ & HM2 \\
\hline Robin & Turdus migratorius & 12 & OB \\
\hline
\end{tabular}


Table 3. Beta animal guilds of the Tallgrass Prairie Preserve, OK (Cont.)

\begin{tabular}{|c|c|c|c|}
\hline Common name & Scientific name & Source $^{a}$ & $\begin{array}{l}\text { Alpha } \\
\text { guild }^{b}\end{array}$ \\
\hline \multicolumn{4}{|l|}{ Grassy Riparian Guild (cont.) } \\
\hline Starling & Sturnus vulgaris & 12 & OB \\
\hline Coyote & Canis latrans & 1,2 & OM1 \\
\hline Nine-banded Armadillo & Dasypus novemcinctus & 1 & OM1 \\
\hline Raccoon & Procyon lotor & 1,2 & OM1 \\
\hline Deer Mouse & Peromyscus maniculatus & $1,2,11$ & OM2 \\
\hline Fulvous Harvest Mouse & Reithrodontomys fulvescens & $1,2,11$ & OM2 \\
\hline Plains Harvest Mouse & Reithrodontomys montanus & $1,2,11$ & OM2 \\
\hline White-footed Mouse & Peromyscus leucopus & 11 & OM2 \\
\hline \multicolumn{4}{|l|}{ Prairie Guild } \\
\hline Flycatcher, scissor-tailed & Tyrannus forficatus & 12 & CB1 \\
\hline Kingbird, eastern & Tyrannus tyrannus & 12 & CB1 \\
\hline Kingbird, western & Tyrannus verticalis & 12 & CB1 \\
\hline Loggerhead shrike & Lanius ludovicianus & 12 & CB1 \\
\hline Nighthawk & Chordeiles minor & 12 & CB1 \\
\hline Poorwill & Phalaenoptilus nuttallii & 12 & CB1 \\
\hline Purple martin & Progne subis & 12 & CB1 \\
\hline Sandpiper, upland & Bartramia longicauda & 12 & CB1 \\
\hline Swallow, barn & Hirundo rustica & 12 & CB1 \\
\hline Swallow, cliff & Hirundo pyrrhonata & 12 & CB1 \\
\hline Swallow, rough-winged & Stelgidopteryx serripennis & 12 & CB1 \\
\hline Yellowthroat, common & Geothlypis trichas & 12 & CB1 \\
\hline Falcon, peregrine & Falco peregrinus & 12 & CB2 \\
\hline Harrier, northern & Circus cyaneus & 12 & CB2 \\
\hline Hawk, rough-legged & Buteo lagopus & 12 & CB2 \\
\hline Hawk, Swainson's & Buteo swainsoni & 12 & CB2 \\
\hline Merlin & Falco columbarius & 12 & CB2 \\
\hline Owl, burrowing & Athene cunicularia & 12 & CB2 \\
\hline Owl, short-eared & Asio flammeus & 12 & CB2 \\
\hline Vulture, turkey & Cathartes aura & 12 & CB2 \\
\hline Brown Snake & Storeria dekayi & 2,7 & $\mathrm{CH1}$ \\
\hline Dwarf American Toad & Bufo americanus & 2,7 & $\mathrm{CH} 1$ \\
\hline
\end{tabular}


Table 3. Beta animal guilds of the Tallgrass Prairie Preserve, OK (Cont.)

\begin{tabular}{|c|c|c|c|}
\hline Common name & Scientific name & Source $^{a}$ & $\begin{array}{l}\text { Alpha } \\
\text { guild }^{\text {b }}\end{array}$ \\
\hline \multicolumn{4}{|l|}{ Prairie Guild (cont.) } \\
\hline Great Plains Narrowmouth Toad & Gastrophryne olivacea & 2,8 & CH1 \\
\hline Great Plains Skink & Eumeces obsoletus & 2,8 & CH1 \\
\hline Lined Snake & Tropidoclonium lineatum & 2,7 & $\mathrm{CH1}$ \\
\hline Plains Leopard Frog & Rana blairi & 2,7 & CH1 \\
\hline Six-lined Racerunner & Cnemidophorus sexlineatus & 2,7 & CH1 \\
\hline Southern Leopard Frog & Rana utricularia & 2,7 & $\mathrm{CH} 1$ \\
\hline Southern Prairie Skink & Eumeces septentrionalis & 2,9 & CH1 \\
\hline Strecker's Chorus Frog & Pseudacris streckeri & 2,7 & $\mathrm{CH} 1$ \\
\hline Western Chorus Frog & Pseudacris triseriata & 2,7 & $\mathrm{CH} 1$ \\
\hline Black Ratsnake & Elaphe obseleta & 2,7 & $\mathrm{CH} 2$ \\
\hline Broad-banded Copperhead & Agkistrodon contortrix & 2,7 & $\mathrm{CH} 2$ \\
\hline Bullsnake & Pituophis melanoleucus & 2,7 & $\mathrm{CH} 2$ \\
\hline Central Plains Milk Snake & Lampropeltis triangulum & 2,7 & $\mathrm{CH} 2$ \\
\hline Coachwhip & Masticophis flagellum & 2,7 & $\mathrm{CH} 2$ \\
\hline Crawfish Frog & Rana areolata & 2,7 & $\mathrm{CH} 2$ \\
\hline Great Plains Ratsnake & Elaphe guttata & 2,7 & $\mathrm{CH} 2$ \\
\hline Massasauga & Sistrurus catenatus & 2,7 & $\mathrm{CH} 2$ \\
\hline Prairie Kingsnake & Lampropeltis calligaster & 2,7 & $\mathrm{CH} 2$ \\
\hline Western Glass Lizard & Ophisaurus attenuatus & 2,7 & $\mathrm{CH} 2$ \\
\hline Least Shrew & Cryptotis parva & $1,2,11$ & CM1A \\
\hline Badger & Taxidea taxus & 1,2 & CM2 \\
\hline Bobcat & Felis rufus & 1,2 & CM2 \\
\hline Mountain Lion & Felis concolor & 1,2 & CM2 \\
\hline Bison & Bison bison & 1,2 & HM1A \\
\hline Cow & Bos spp. & 13 & HM1A \\
\hline Prairie Vole & Microtus ochrogaster & $1,2,11$ & HM1B \\
\hline White tailed Deer & Odocoileus virginianus & 1,2 & HM1B \\
\hline Black-tailed Jack Rabbit & Lepus californicus & $1,2,3$ & HM2 \\
\hline Eastern Woodrat & Neotoma floridana & $1,2,11$ & HM2 \\
\hline Elliot's Short-tailed shrew & Blarina hylophaga & $1,2,11$ & HM2 \\
\hline Hispid Cotton Rat & Sigmodon hispidus & $1,2,11$ & HM2 \\
\hline
\end{tabular}


Table 3. Beta animal guilds of the Tallgrass Prairie Preserve, OK (Cont.)

\begin{tabular}{|c|c|c|c|}
\hline Common name & Scientific name & Source $^{a}$ & $\begin{array}{l}\text { Alpha } \\
\text { guild }^{\text {b }}\end{array}$ \\
\hline \multicolumn{4}{|l|}{ Prairie Guild (cont.) } \\
\hline House Mouse & Mus musculus & $1,2,11$ & HM2 \\
\hline Woodland Vole & Microtus pinetorum & $1,2,11$ & HM2 \\
\hline Bobwhite & Colinus virginianus & 12 & OB \\
\hline Cowbird, brown-headed & Molothrus ater & 12 & OB \\
\hline Dickcissel & Spiza americana & 12 & OB \\
\hline Dove, mourning & Zenaida macroura & 12 & OB \\
\hline Great prairie chicken & Tympanuchus cupido & 12 & OB \\
\hline Gull, Franklin's & Larus pipixcan & 12 & OB \\
\hline Gull, ring-billed & Larus delawarensis & 12 & OB \\
\hline Horned lark & Eremophila alpestris & 12 & OB \\
\hline Junco, dark-eyed & Junco hyemalis & 12 & OB \\
\hline Meadowlark, eastern & Sturnella magna & 12 & OB \\
\hline Pheasant, ring-necked & Phasianus colchicus & 12 & OB \\
\hline Plover, lesser golden & Pluvialis squatarola & 12 & OB \\
\hline Sparrow, American tree & Spizella arborea & 12 & OB \\
\hline Sparrow, Harris' & Zonotrichia querula & 12 & OB \\
\hline Sparrow, Henslow's & Ammodramus henslowii & 12 & OB \\
\hline Sparrow, lark & Chondestes grammacus & 12 & OB \\
\hline Sparrow, savannah & Passerculus sandwichensis & 12 & OB \\
\hline Sparrow, vesper & Pooecetes gramineus & 12 & OB \\
\hline Ornate Box Turtle & Terrapene ornata & 2,7 & $\mathrm{OH}$ \\
\hline Coyote & Canis latrans & 1,2 & OM1 \\
\hline Gray Fox & Urocyon cinereoargenteus & 2,3 & OM1 \\
\hline Kerr, Virginia opossum & Didelphis virginiana & 1,2 & OM1 \\
\hline Nine-banded Armadillo & Dasypus novemcinctus & 1 & OM1 \\
\hline 13-lined Ground Squirrel & Spermophilus tridecimlineatus & 2,3 & OM2 \\
\hline Deer Mouse & Peromyscus maniculatus & $1,2,11$ & OM2 \\
\hline Eastern Harvest Mouse & Reithrodontomys humulis & $1,2,11$ & OM2 \\
\hline Fulvous Harvest Mouse & Reithrodontomys fulvescens & $1,2,11$ & OM2 \\
\hline
\end{tabular}


Table 3. Beta animal guilds of the Tallgrass Prairie Preserve, OK (Cont.)

\begin{tabular}{|c|c|c|c|}
\hline Common name & Scientific name & Source $^{\mathrm{a}}$ & $\begin{array}{l}\text { Alpha } \\
\text { guild }^{\text {b }}\end{array}$ \\
\hline \multicolumn{4}{|l|}{ Prairie Guild (cont.) } \\
\hline Plains Harvest Mouse & Reithrodontomys montanus & $1,2,11$ & OM2 \\
\hline Western Harvest Mouse & Reithrodontomys megalotis & $1,2,5,11$ & OM2 \\
\hline White-footed Mouse & Peromyscus leucopus & $1,2,11$ & OM2 \\
\hline \multicolumn{4}{|c|}{ Upland Deciduous Forest Guild } \\
\hline Flycatcher, great crested & Myiarchus crinitus & 12 & CB1 \\
\hline Flycatcher, least & Empidomax minimus & 12 & CB1 \\
\hline Flycatcher, willow & Empidomax traillii & 12 & CB1 \\
\hline Gnatcatcher, blue-gray & Polioptila caerulea & 12 & CB1 \\
\hline Kingbird, eastern & Tyrannus tyrannus & 12 & CB1 \\
\hline Kinglet, golden-crowned & Regulus satrapa & 12 & CB1 \\
\hline Loggerhead shrike & Lanius ludovicianus & 12 & CB1 \\
\hline Northern flicker & Colaptes auratus & 12 & CB1 \\
\hline Phoebe, eastern & Savornis phoebe & 12 & CB1 \\
\hline Warbler, black and white & Mniotilta varia & 12 & CB1 \\
\hline Warbler, yellow & Dendroica petechia & 12 & CB1 \\
\hline Woodpecker, downy & Picoides pubescens & 12 & CB1 \\
\hline Woodpecker, hairy & Picoides villosus & 12 & CB1 \\
\hline Woodpecker, red-bellied & Melanerpes carolinus & 12 & CB1 \\
\hline Wood-pewee, eastern & Contopus virens & 12 & CB1 \\
\hline Wren, Bewick's & Thryomanes bewickii & 12 & CB1 \\
\hline Yellow-billed cuckoo & Coccyzus americanus & 12 & CB1 \\
\hline Harrier, northern & Circus cyaneus & 12 & CB2 \\
\hline Hawk, Cooper's & Accipiter cooperii & 12 & CB2 \\
\hline Hawk, red-tailed & Buteo jamaicensus & 12 & CB2 \\
\hline Kestrel & Falco sparverius & 12 & CB2 \\
\hline Kite, Mississippi & Ictinia mississippiensis & 12 & CB2 \\
\hline Owl, great horned & Bubo virginianus & 12 & CB2 \\
\hline Owl, screech & Otus asio & 12 & CB2 \\
\hline Broadhead Skink & Eumeces laticeps & 2,7 & CH1 \\
\hline Brown Snake & Storeria dekayi & 2,7 & CH1 \\
\hline Fence Lizard & Sceloporus undulatus & 2,7 & CH1 \\
\hline
\end{tabular}


Table 3. Beta animal guilds of the Tallgrass Prairie Preserve, OK (Cont.)

\begin{tabular}{|c|c|c|c|}
\hline Common name & Scientific name & Source $^{a}$ & $\begin{array}{l}\text { Alpha } \\
\text { guild }^{\text {b }}\end{array}$ \\
\hline \multicolumn{4}{|c|}{ Upland Deciduous Forest Guild (cont.) } \\
\hline Five-lined Skink & Eumeces fasciatus & 2,7 & CH1 \\
\hline Gray Tree Frog & Hyla versicolor & 2,7 & CH1 \\
\hline Ground Skink & Scincella lateralis & 2,7 & $\mathrm{CH} 1$ \\
\hline Black Ratsnake & Elaphe obseleta & 2,7 & $\mathrm{CH} 2$ \\
\hline Broad-banded Copperhead & Agkistrodon contortrix & 2,7 & $\mathrm{CH} 2$ \\
\hline Central Plains Milk Snake & Lampropeltis triangulum & 2,7 & $\mathrm{CH} 2$ \\
\hline Common Garter Snake & Thamnophis sirtalis & 2,7 & $\mathrm{CH} 2$ \\
\hline Eastern Hognose Snake & Heterodon platyrhinos & 2,7 & $\mathrm{CH} 2$ \\
\hline Great Plains Ratsnake & Elaphe guttata & 2,7 & $\mathrm{CH} 2$ \\
\hline Speckled Kingsnake & Lampropeltis getulus & 2,7 & $\mathrm{CH} 2$ \\
\hline Timber Rattlesnake & Crotalus horridus & 2,7 & $\mathrm{CH} 2$ \\
\hline Western Glass Lizard & Ophisaurus attenuatus & 2,7 & $\mathrm{CH} 2$ \\
\hline Yellowbelly Racer & Coluber constrictor & 2,7 & $\mathrm{CH} 2$ \\
\hline Mountain Lion & Felis concolor & 1,2 & $\mathrm{CM} 2$ \\
\hline Bison & Bison bison & 1,2 & HM1A \\
\hline Cow & Bos spp. & 13 & HM1A \\
\hline White tailed Deer & Odocoileus virginianus & 1,2 & HM1B \\
\hline Eastern Cottontail & Sylvilagus floridanus & 1 & HM2 \\
\hline Eastern Woodrat & Neotoma floridana & $1,2,11$ & HM2 \\
\hline Elliot's Short-tailed shrew & Blarina hylophaga & $1,2,11$ & HM2 \\
\hline Hispid Cotton Rat & Sigmodon hispidus & $1,2,11$ & HM2 \\
\hline Woodchuck & Marmota monax & 2,4 & HM2 \\
\hline Blackbird, red-winged & Agelaius phoeniceus & 12 & OB \\
\hline Blue jay & Cyanocitta cristata & 12 & OB \\
\hline Bluebird, eastern & Sialia sialis & 12 & OB \\
\hline Bobwhite & Colinus virginianus & 12 & OB \\
\hline Brown thrasher & Toxostoma rufum & 12 & OB \\
\hline Bunting, indigo & Passerina cyanea & 12 & OB \\
\hline Cardinal & Cardinalis cardinalis & 12 & OB \\
\hline Catbird & Dumetella carolinensis & 12 & OB \\
\hline Cowbird, brown-headed & Molothrus ater & 12 & OB \\
\hline
\end{tabular}


Table 3. Beta animal guilds of the Tallgrass Prairie Preserve, OK (Cont.)

\begin{tabular}{|c|c|c|c|}
\hline Common name & Scientific name & Source $^{a}$ & $\begin{array}{l}\text { Alpha } \\
\text { guild }\end{array}$ \\
\hline \multicolumn{4}{|c|}{ Upland Deciduous Forest Guild (cont.) } \\
\hline Crow, american & Corvus brachyrhynchos & 12 & OB \\
\hline Dove, mourning & Zenaida macroura & 12 & OB \\
\hline Goldfinch, American & Carduelis tristis & 12 & OB \\
\hline Grackle, common & Quiscalus quiscula & 12 & OB \\
\hline Grosbeak, blue & Guiraca caerulea & 12 & OB \\
\hline Junco, dark-eyed & Junco hyemalis & 12 & OB \\
\hline Nuthatch, whitebreasted & Sitta carolenensis & 12 & OB \\
\hline Oriole, Northern & Icterus galbula & 12 & OB \\
\hline Oriole, orchard & Icterus spurius & 12 & OB \\
\hline Robin & Turdus migratorius & 12 & OB \\
\hline Sparrow, American tree & Spizella arborea & 12 & OB \\
\hline Sparrow, chipping & Spizella passerina & 12 & OB \\
\hline Sparrow, field & Spizella pusilla & 12 & OB \\
\hline Sparrow, Harris' & Zonotrichia querula & 12 & OB \\
\hline Sparrow, lark & Chondestes grammacus & 12 & OB \\
\hline Sparrow, Lincoln's & Melospiza lincolnii & 12 & OB \\
\hline Sparrow, song & Melospiza melodia & 12 & OB \\
\hline Sparrow, white-crowned & Zonotrichia leucophrys & 12 & OB \\
\hline Sparrow, white-throated & Zonotrichia albicollis & 12 & OB \\
\hline Starling & Sturnus vulgaris & 12 & OB \\
\hline Towhee, rufous-sided & Pipilo erythrophthalmus & 12 & OB \\
\hline Tufted titmouse & Parus inornatus & 12 & OB \\
\hline Warbler, yellow-rumped & Dendroica coronata & 12 & OB \\
\hline Waxwing, cedar & Bombycilla garrulus & 12 & OB \\
\hline Woodpecker, red-headed & Melanerpes erythrocephalus & 12 & OB \\
\hline Three-toed Box Turtle & Terrapene carolina & 2,7 & $\mathrm{OH}$ \\
\hline Coyote & Canis latrans & 1,2 & OM1 \\
\hline Gray Fox & Urocyon cinereoargenteus & 2,3 & OM1 \\
\hline Nine-banded Armadillo & Dasypus novemcinctus & 1 & OM1 \\
\hline Raccoon & Procyon lotor & 1,2 & OM1 \\
\hline Cotton Mouse & Peromyscus gossypinus & $1,2,11$ & OM2 \\
\hline
\end{tabular}


Table 3. Beta animal guilds of the Tallgrass Prairie Preserve, OK (Cont.)

\begin{tabular}{|c|c|c|c|}
\hline Common name & Scientific name & Source $^{a}$ & $\begin{array}{l}\text { Alpha } \\
\text { guild }^{\text {b }}\end{array}$ \\
\hline \multicolumn{4}{|l|}{ Upland Deciduous Forest Guild (cont.) } \\
\hline Deer Mouse & Peromyscus maniculatus & $1,2,11$ & OM2 \\
\hline White-footed Mouse & Peromyscus leucopus & $1,2,11$ & OM2 \\
\hline \multicolumn{4}{|l|}{ Rocky Outcrops } \\
\hline Vireo, Bell's & Vireo bellii & 12 & CB1 \\
\hline Warbler, yellow & Dendroica petechia & 12 & CB1 \\
\hline Wren, Bewick's & Thryomanes bewickii & 12 & CB1 \\
\hline Brown Snake & Storeria dekayi & 2,7 & $\mathrm{CH} 1$ \\
\hline Black Ratsnake & Elaphe obseleta & 2,7 & $\mathrm{CH} 2$ \\
\hline Central Plains Milk Snake & Lampropeltis triangulum & 2,7 & $\mathrm{CH} 2$ \\
\hline Coachwhip & Masticophis flagellum & 2,7 & $\mathrm{CH} 2$ \\
\hline Eastern Collared Lizard & Crotaphytus collaris & 2,7 & $\mathrm{CH} 2$ \\
\hline Great Plains Ratsnake & Elaphe guttata & 2,7 & $\mathrm{CH} 2$ \\
\hline Timber Rattlesnake & Crotalus horridus & 2,7 & $\mathrm{CH} 2$ \\
\hline Mountain Lion & Felis concolor & 1,2 & $\mathrm{CM} 2$ \\
\hline Bison & Bison bison & 1,2 & HM1A \\
\hline Cow & Bos spp. & 13 & HM1A \\
\hline Fence Lizard & Sceloporus undulatus & 2,7 & HM1B \\
\hline Flathead Snake & Tantilla gracilis & 2,7 & HM1B \\
\hline Great Plains Narrowmouth Toad & Gastrophryne olivacea & 2,8 & HM1B \\
\hline Ground Snake & Sonora semiannulata & 2,10 & HM1B \\
\hline Six-lined Racerunner & Cnemidophorus sexlineatus & $1,2,11$ & HM1B \\
\hline Southern Prairie Skink & Eumeces septentrionalis & 2,7 & HM1B \\
\hline White tailed Deer & Odocoileus virginianus & 1,2 & HM1B \\
\hline Eastern Cottontail & Sylvilagus floridanus & 1 & HM2 \\
\hline Eastern Woodrat & Neotoma floridana & $1,2,11$ & HM2 \\
\hline Hispid Cotton Rat & Sigmodon hispidus & $1,2,11$ & HM2 \\
\hline Hispid Pocket Mouse & Chaetodipus hispidus & $1,2,11$ & HM2 \\
\hline Bluebird, mountain & Sialia currucoides & 12 & OB \\
\hline Brown thrasher & Toxostoma rufum & 12 & OB \\
\hline Cardinal & Cardinalis cardinalis & 12 & OB \\
\hline Catbird & Dumetella carolinensis & 12 & OB \\
\hline
\end{tabular}


Table 3. Beta animal guilds of the Tallgrass Prairie Preserve, OK (Cont.)

\begin{tabular}{|c|c|c|c|}
\hline Common name & Scientific name & Source $^{a}$ & $\begin{array}{l}\text { Alpha } \\
\text { guild }^{\mathrm{b}}\end{array}$ \\
\hline \multicolumn{4}{|l|}{ Rocky Outcrops (cont.) } \\
\hline Cowbird, brown-headed & Molothrus ater & 12 & OB \\
\hline Mockingbird & Mimus polyglottos & 12 & OB \\
\hline Pheasant, ring-necked & Phasianus colchicus & 12 & OB \\
\hline Sparrow, American tree & Spizella arborea & 12 & OB \\
\hline Sparrow, song & Melospiza melodia & 12 & OB \\
\hline Coyote & Canis latrans & 1,2 & OM1 \\
\hline Nine-banded Armadillo & Dasypus novemcinctus & 1 & OM1 \\
\hline 13-lined Ground Squirrel & Spermophilus tridecimlineatus & 2,6 & OM2 \\
\hline Deer Mouse & Peromyscus maniculatus & $1,2,11$ & OM2 \\
\hline Fulvous Harvest Mouse & Reithrodontomys fulvescens & $1,2,11$ & OM2 \\
\hline White-footed Mouse & Peromyscus leucopus & $1,2,11$ & OM2 \\
\hline \multicolumn{4}{|l|}{ Disturbed Areas } \\
\hline Killdeer & Charadrius vociferous & 12 & CB1 \\
\hline Brown Snake & Storeria dekayi & 2,7 & $\mathrm{CH1}$ \\
\hline Dwarf American Toad & Bufo americanus & 2,7 & $\mathrm{CH1}$ \\
\hline Lined Snake & Tropidoclonium lineatum & 2,7 & $\mathrm{CH1}$ \\
\hline Black Ratsnake & Elaphe obseleta & 2,7 & $\mathrm{CH} 2$ \\
\hline Least Shrew & Cryptotis parva & $1,2,11$ & CM1A \\
\hline Badger & Taxidea taxus & 1,2 & CM2 \\
\hline Bobcat & Felis rufus & 1,2 & CM2 \\
\hline Bison & Bison bison & 1,2 & HM1A \\
\hline White tailed Deer & Odocoileus virginianus & 1,2 & HM1B \\
\hline Black-tailed Jack Rabbit & Lepus californicus & $1,2,3$ & HM2 \\
\hline Eastern Cottontail & Sylvilagus floridanus & 1 & HM2 \\
\hline Eastern Woodrat & Neotoma floridana & 11 & HM2 \\
\hline Hispid Cotton Rat & Sigmodon hispidus & $1,2,11$ & HM2 \\
\hline Hispid Pocket Mouse & Chaetodipus hispidus & $1,2,11$ & HM2 \\
\hline House Mouse & Mus musculus & $1,2,11$ & HM2 \\
\hline Prairie Vole & Microtus ochrogaster & $1,2,11$ & HM2 \\
\hline Chimney swift & Chaetura pelagica & 12 & OB \\
\hline Dove, rock & Columba livia & 12 & OB \\
\hline
\end{tabular}


Table 3. Beta animal guilds of the Tallgrass Prairie Preserve, OK (Cont.)

\begin{tabular}{llcc}
\hline \hline Common name & Scientific name & Source $^{\mathrm{a}}$ & $\begin{array}{l}\text { Alpha } \\
\text { guild }^{\mathrm{b}}\end{array}$ \\
\hline $\begin{array}{l}\text { Disturbed Areas (cont.) } \\
\text { Sparrow, house }\end{array}$ & Passer domesticus & 12 & OB \\
Coyote & Canis latrans & 1,2 & OM1 \\
Nine-banded Armadillo & Dasypus novemcinctus & 1 & OM1 \\
Striped Skunk & Mephitis mephitis & 1,2 & OM1 \\
Deer Mouse & Peromyscus maniculatus & $1,2,11$ & OM2 \\
Fulvous Harvest Mouse & Reithrodontomys fulvescens & $1,2,11$ & OM2 \\
White-footed Mouse & Peromyscus leucopus & $1,2,11$ & OM2 \\
\hline \hline
\end{tabular}

a Indicates source for both presence/absence and distribution. Sources: 1. Oklahoma Natural Heritage Inventory, 1993; 2. Nature Conservancy, 1993; 3. Myers et al., 2000; 4. McMillan et al., 1997; 5. McMillan and Kaufman, 1994; 6. Finck et al., 1986; 7. INHS, 1998; 8. Bockstanz and Cannatella, 2000; 9. LeClere, 2000; 10. Cossel, 1998; 11. Payne and Caire, 1999; 12. Zimmerman, 1993; 13. Hamilton, 1996.

b Key to Alpha Guilds:

$\begin{array}{llll}\text { HM1a } & \text { Herbivorous Mammals - grazers } & \text { CH1 } & \text { Invertivorous Herptiles } \\ \text { HM1b } & \text { Herbivorous Mammals - browsers } & \text { CH2 } & \text { Other Carnivorous Herptiles } \\ \text { HM2 } & \text { Small Herbivorous Mammals } & \text { CB1 } & \text { Invertivorous Birds } \\ \text { HB } & \text { Herbivorous Birds } & \text { CB2 } & \text { Raptors } \\ \text { OM1 } & \text { Large Omnivorous Mammals } & \text { CM1a } & \text { Fossorial Invertivorous Mammals } \\ \text { OM2 } & \text { Small Omnivorous Mammals } & \text { CM1b } & \text { Other Invertivorous Mammals } \\ \text { OB } & \text { Omnivorous Birds } & \text { CM2 } & \text { Large Carnivorous Mammals } \\ \text { OH } & \text { Omnivorous Herptiles } & & \end{array}$


Table 4. Dominant Plant Species at the Tallgrass Prairie Preserve, OK. Based on unbiased plots sampled throughout the entire preserve. Source: Palmer, unpublished data.

\begin{tabular}{|c|c|c|}
\hline Species name & $\begin{array}{c}\text { Frequency } \\
\text { (\% of plots } \\
\text { occupied) }\end{array}$ & $\begin{array}{c}\text { Average } \\
\text { cover } \\
(\%) \\
\end{array}$ \\
\hline Andropogon gerardii & 97.4 & 4 \\
\hline Sporobolus compositus & 97.4 & 2.8 \\
\hline Oxalis dillenii & 96 & 0.5 \\
\hline Ambrosia psilostachya & 95.4 & 1.5 \\
\hline Asclepias viridis & 92.1 & 0.5 \\
\hline Dichanthelium oligosanthes & 91.4 & 0.5 \\
\hline Sorghastrum nutans & 88.1 & 1.3 \\
\hline Panicum virgatum & 87.4 & 0.7 \\
\hline Schizachyrium scoparium & 86.8 & 2.3 \\
\hline Strophostyles leiosperma & 83.4 & 0.4 \\
\hline Aster ericoides & 80.8 & 0.5 \\
\hline Carex festucacea & 79.5 & 0.4 \\
\hline Erigeron strigosus & 78.8 & 0.4 \\
\hline Kummerowia stipulacea & 77.5 & 0.5 \\
\hline Achillea millefolium & 74.8 & 0.4 \\
\hline Carex microdonta & 72.2 & 0.5 \\
\hline Ruellia humilis & 71.5 & 0.3 \\
\hline Elymus virginicus & 70.2 & 0.4 \\
\hline Vernonia baldwinii & 67.5 & 0.5 \\
\hline Amphiachyris dracunculoides & 66.9 & 0.4 \\
\hline Eragrostis spectabilis & 63.6 & 0.4 \\
\hline Plantago virginica & 61.6 & 0.3 \\
\hline Setaria parviflora & 60.3 & 0.3 \\
\hline Solanum carolinense & 60.3 & 0.3 \\
\hline Juncus interior & 59.6 & 0.3 \\
\hline Paspalum setaceum & 58.9 & 0.3 \\
\hline Poa pratensis & 57.6 & 0.3 \\
\hline Ambrosia artemisiifolia & 55.6 & 0.5 \\
\hline Salvia azurea & 55.6 & 0.3 \\
\hline Cirsium altissimum & 55 & 0.3 \\
\hline Conyza canadensis & 55 & 0.2 \\
\hline Acalypha gracilens & 54.3 & 0.2 \\
\hline Physalis pumila & 52.3 & 0.3 \\
\hline Lespedeza procumbens & 51.7 & 0.4 \\
\hline
\end{tabular}

\begin{tabular}{lcc}
\hline \hline & $\begin{array}{c}\text { Frequency } \\
\text { (\%) of plots } \\
\text { occupied) }\end{array}$ & $\begin{array}{c}\text { Average } \\
\text { cover } \\
\text { (\%) }\end{array}$ \\
Species name & 51.7 & 0.3 \\
\hline Sphenopholis obtusata & 51.7 & 0.2 \\
Oxalis violacea & 51 & 0.3 \\
Tridens flavus & 50.3 & 0.3 \\
Elymus canadensis & 50.3 & 0.2 \\
Ratibida columnifera & 50.3 & 0.2 \\
Digitaria cognata & 49.7 & 0.4 \\
Artemisia ludoviciana & 49.7 & 0.3 \\
Agrostis hyemalis & 49.7 & 0.2 \\
Croton monanthogynus & 49 & 0.6 \\
Solidago canadensis & 49 & 0.3 \\
Amorpha canescens & 48.3 & 0.4 \\
Psoralidium tenuiflorum & 48.3 & 0.2 \\
Carex bushii & 46.4 & 0.2 \\
Cyperus lupulinus & 46.4 & 0.2 \\
Dichanthelium acuminatum & 46.4 & 0.2 \\
Polygala verticillata & 46.4 & 0.2 \\
Lepidium virginicum & 45.7 & 0.2 \\
Physalis virginiana & 45.7 & 0.2 \\
Hordeum pusillum & 45 & 0.2 \\
Lespedeza virginica & 45 & 0.2 \\
Triodanis perfoliata & 43.7 & 0.4 \\
Bothriochloa saccharoides & 43.7 & 0.3 \\
Symphoricarpos orbiculatus & 43.7 & 0.2 \\
Carex gravida & 43.7 & 0.2 \\
Mimosa quadrivalvis & 43 & 0.2 \\
Callirhoe alcaeoides & 41.7 & 0.2 \\
Carex cephalophora & 41.7 & 0.2 \\
Cuscuta pentagona & 41.1 & 0.3 \\
Buchloe dactyloides & 41.1 & 0.3 \\
Bromus japonicus & 41.1 & 0.2 \\
Acalypha virginica & 0.7 \\
Rubus ostryifolius & 0.3 \\
Bouteloua curtipendula &
\end{tabular}


Table 4. Dominant Plant Species at the Tallgrass Prairie Preserve, OK (Cont.).

\begin{tabular}{|c|c|c|}
\hline Species name & $\begin{array}{l}\text { Frequency } \\
\text { (\% of plots } \\
\text { occupied) }\end{array}$ & $\begin{array}{c}\text { Average } \\
\text { cover } \\
(\%)\end{array}$ \\
\hline Eleocharis montevidensis & 40.4 & 0.3 \\
\hline Cirsium undulatum & 40.4 & 0.2 \\
\hline Kummerowia striata & 39.7 & 0.4 \\
\hline Fimbristylis puberula & 37.7 & 0.2 \\
\hline Chamaesyce nutans & 37.7 & 0.1 \\
\hline Ambrosia bidentata & 36.4 & 0.2 \\
\hline Chaerophyllum tainturieri & 33.1 & 0.1 \\
\hline Cyperus echinatus & 32.5 & 0.2 \\
\hline Aster oolentangiensis & 31.8 & 0.2 \\
\hline Panicum anceps & 30.5 & 0.5 \\
\hline Sisyrinchium campestre & 30.5 & 0.1 \\
\hline Hedeoma hispida & 30.5 & 0.1 \\
\hline Medicago lupulina & 27.8 & 0.3 \\
\hline Oenothera speciosa & 27.8 & 0.1 \\
\hline Rudbeckia hirta & 25.8 & 0.2 \\
\hline Erigeron philadelphicus & 25.8 & 0.1 \\
\hline Linum sulcatum & 25.8 & 0.1 \\
\hline Chamaecrista fasciculata & 25.8 & 0.1 \\
\hline Rumex crispus & 25.2 & 0.1 \\
\hline Desmodium sessilifolium & 25.2 & 0.1 \\
\hline Geranium carolinianum & 25.2 & 0.1 \\
\hline Gamochaeta purpurea & 24.5 & 0.1 \\
\hline Monarda citriodora & 23.8 & 0.2 \\
\hline Vernonia arkansana & 23.8 & 0.1 \\
\hline Brickellia eupatorioides & 23.8 & 0.1 \\
\hline Dalea candida & 23.8 & 0.1 \\
\hline Dracopis amplexicaulis & 23.8 & 0.1 \\
\hline Pyrrhopappus carolinianus & 23.8 & 0.1 \\
\hline Baptisia bracteata & 23.2 & 0.1 \\
\hline Coreopsis grandiflora & 23.2 & 0.1 \\
\hline
\end{tabular}

\begin{tabular}{|c|c|c|}
\hline Species name & $\begin{array}{l}\text { Frequency } \\
\text { (\% of plots } \\
\text { occupied) }\end{array}$ & $\begin{array}{c}\text { Average } \\
\text { cover } \\
(\%) \\
\end{array}$ \\
\hline Tragia betonicifolia & 22.5 & 0.1 \\
\hline Baptisia australis & 21.9 & 0.1 \\
\hline Penstemon tubiflorus & 21.9 & 0.1 \\
\hline Apocynum cannabinum & 21.2 & 0.1 \\
\hline Silene antirrhina & 21.2 & 0.1 \\
\hline Vulpia octoflora & 21.2 & 0.1 \\
\hline Arnoglossum plantagineum & 20.5 & 0.1 \\
\hline Euphorbia spathulata & 19.9 & 0.1 \\
\hline Ulmus rubra & 19.9 & 0.1 \\
\hline Melilotus officinalis & 18.5 & 0.1 \\
\hline Eupatorium altissimum & 18.5 & 0.1 \\
\hline Phalaris caroliniana & 18.5 & 0.1 \\
\hline Valerianella radiata & 18.5 & 0.1 \\
\hline Veronica arvensis & 18.5 & 0.1 \\
\hline Andropogon virginicus & 17.9 & 0.3 \\
\hline Krigia cespitosa & 17.9 & 0.1 \\
\hline Antennaria neglecta & 17.2 & 0.1 \\
\hline Xanthium strumarium & 17.2 & 0.1 \\
\hline Scutellaria parvula & 16.6 & 0.1 \\
\hline Dichanthelium sphaerocarpon & 16.6 & 0.1 \\
\hline Stylosanthes biflora & 16.6 & 0.1 \\
\hline Baptisia alba & 15.9 & 0.1 \\
\hline Desmanthus leptolobus & 15.9 & 0.1 \\
\hline Croton glandulosus & 15.9 & 0.1 \\
\hline Nothoscordum bivalve & 15.9 & 0.1 \\
\hline Desmanthus illinoensis & 15.2 & 0.1 \\
\hline Juncus marginatus & 15.2 & 0.1 \\
\hline Lithospermum incisum & 15.2 & 0.1 \\
\hline Viola sororia & 15.2 & 0.1 \\
\hline
\end{tabular}


Table 5. Food relationships between the various alpha guilds at the Tallgrass Prairie Preserve, OK. An "x" denotes that a given prey species along the $\mathrm{y}$-axis may be consumed by the corresponding predator on the $\mathrm{x}$-axis.

$$
\text { Predators }
$$

\begin{tabular}{|c|c|c|c|c|c|c|c|c|c|c|c|c|c|c|c|c|c|}
\hline & & AI & BI & HM1a & HM1b & HM2 & OM1 & $\mathrm{OM} 2$ & OB & $\mathrm{OH}$ & $\mathrm{CH} 1$ & $\mathrm{CH} 2$ & CB1 & CB2 & CM1a & CM1b & CM2 \\
\hline & Plants & $\mathrm{X}$ & $\mathrm{X}$ & $\mathrm{X}$ & $\mathrm{X}$ & $\mathrm{X}$ & X & $\mathrm{X}$ & $X$ & X & & & & & & & \\
\hline & Detritus & $\mathrm{X}$ & $\mathrm{X}$ & & & & X & $\mathrm{X}$ & $X$ & $\mathrm{X}$ & & & & $\mathrm{X}$ & $\mathrm{X}$ & & \\
\hline & AI & $\mathrm{X}$ & & & & & $\mathrm{X}$ & $\mathrm{X}$ & $\mathrm{X}$ & $\mathrm{X}$ & X & $\mathrm{X}$ & X & $\mathrm{X}$ & & X & \\
\hline & BI & & X & & & & & & $\mathrm{X}$ & $\mathrm{X}$ & X & & $\mathrm{X}$ & & $\mathrm{X}$ & & \\
\hline & HM1a & & & & & & $\mathrm{X}$ & & & & & & & & & & $\mathrm{X}$ \\
\hline & HM1b & & & & & & $\mathrm{X}$ & & & & & & & & & & X \\
\hline & HM2 & & & & & & $\mathrm{X}$ & & $\mathrm{X}$ & & & X & & $\mathrm{X}$ & & & X \\
\hline & OM1 & & & & & & X & & & & & & & X & & & X \\
\hline$\lambda$ & OM2 & & & & & & $\mathrm{X}$ & & $\mathrm{X}$ & & & $\mathrm{X}$ & & $\mathrm{X}$ & & & $\mathrm{X}$ \\
\hline$\Xi$ & OB & & & & & & $\mathrm{X}$ & & $\mathrm{X}$ & X & & $\mathrm{X}$ & & $\mathrm{X}$ & & & $\mathrm{X}$ \\
\hline & $\mathrm{OH}$ & & & & & & $\mathrm{X}$ & & & & & & & & & & $\mathrm{X}$ \\
\hline & CH1 & & & & & & $\mathrm{X}$ & $\mathrm{X}$ & $\mathrm{X}$ & & & $\mathrm{X}$ & & $\mathrm{X}$ & & & $\mathrm{X}$ \\
\hline & $\mathrm{CH} 2$ & & & & & & $\mathrm{X}$ & & & & & $\mathrm{X}$ & & X & & & X \\
\hline & CB1 & & & & & & $\mathrm{X}$ & & $\mathrm{X}$ & $\mathrm{X}$ & & $\mathrm{X}$ & & $\mathrm{X}$ & & & $\mathrm{X}$ \\
\hline & CB2 & & & & & & & & & & & & & & & & \\
\hline & CM1a & & & & & & X & & & & & $\mathrm{X}$ & & X & & & $\mathrm{X}$ \\
\hline & CM1b & & & & & & $\bar{X}$ & & & & & & & $\mathrm{X}$ & & & \\
\hline & CM2 & & & & & & & & & & & & & & & & \\
\hline
\end{tabular}

Plants

Plants and Fungi

Detritus Detritus and Carrion

AI Aboveground Invertebrates

BI Belowground Invertebrates

HM1a Herbivorous Mammals - grazers

HM1b Herbivorous Mammals - browsers

HM2 Small Herbivorous Mammals

HB Herbivorous Birds

OM1 Large Omnivorous Mammals

OM2 Small Omnivorous Mammals $\underline{\text { Key to Alpha Guilds: }}$

$\begin{array}{cl}\text { OB } & \text { Omnivorous Birds } \\ \text { OH } & \text { Omnivorous Herptiles } \\ \text { CH1 } & \text { Invertivorous Herptiles } \\ \text { CH2 } & \text { Other Carnivorous Herptiles } \\ \text { CB1 } & \text { Invertivorous Birds } \\ \text { CB2 } & \text { Raptors } \\ \text { CM1a } & \text { Fossorial Invertivorous Mammals } \\ \text { CM1b } & \text { Other Invertivorous Mammals } \\ \text { CM2 } & \text { Large Carnivorous Mammals }\end{array}$


Table 6. Metaguilds at the Tallgrass Prairie Preserve, OK. All guilds within each metaguild share either identical prey guilds, or identical predator guilds.

\begin{tabular}{lcc}
\hline Predator Metaguild & Constituent Guilds & Guilds used as Prey \\
\hline $\begin{array}{l}\text { Herbivorous Mammals } \\
\text { Invertivores }\end{array}$ & HM1a, HM1b, HM2 & Plants \\
\hline Prey Metaguild & Const, CB1 & GI \\
\hline Metaguild A & HM1a, HM1b, OH & OM1, CM2 \\
Metaguild B & HM2, OM2, CM1a, CH2 & OM1, OB, CH2, CB2, CM2 \\
Metaguild C (Non-raptorial Birds) & $\mathrm{OB}, \mathrm{CB} 1$ & $\mathrm{OM} 1, \mathrm{OB}, \mathrm{OH}, \mathrm{CH} 2, \mathrm{CB} 2, \mathrm{CM} 2$ \\
Metaguild D (Top Predators) & $\mathrm{CB} 2, \mathrm{CM} 2$ & none
\end{tabular}

\begin{tabular}{|c|c|c|c|}
\hline \multicolumn{4}{|c|}{ Key to Alpha Guilds: } \\
\hline Plants & Plants and Fungi & $\mathrm{OB}$ & Omnivorous Birds \\
\hline Detritus & Detritus and Carrion & $\mathrm{OH}$ & Omnivorous Herptiles \\
\hline AI & Aboveground Invertebrates & CH1 & Invertivorous Herptiles \\
\hline BI & Belowground Invertebrates & $\mathrm{CH} 2$ & Other Carnivorous Herptiles \\
\hline HM1a & Herbivorous Mammals - grazers & CB1 & Invertivorous Birds \\
\hline HM1b & Herbivorous Mammals - browsers & CB2 & Raptors \\
\hline HM2 & Small Herbivorous Mammals & CM1a & Fossorial Invertivorous Mammals \\
\hline HB & Herbivorous Birds & CM1b & Other Invertivorous Mammals \\
\hline OM1 & Large Omnivorous Mammals & CM2 & Large Carnivorous Mammals \\
\hline OM2 & Small Omnivorous Mammals & & \\
\hline
\end{tabular}




\section{Appendix A \\ Master Species List of the Tallgrass Prairie Preserve, OK}


Table A-1. Master Species List of the Tallgrass Prairie Preserve, OK.

\begin{tabular}{|c|c|c|c|c|c|c|c|c|c|c|}
\hline \multirow[b]{2}{*}{ Common name } & \multirow[b]{2}{*}{ Scientific name } & \multirow[b]{2}{*}{$\begin{array}{l}\text { Trophic } \\
\text { level }^{\mathrm{a}}\end{array}$} & \multicolumn{7}{|c|}{ Habitat $^{b}$} & \multirow[b]{2}{*}{ Source $^{c}$} \\
\hline & & & $\begin{array}{l}\text { Deciduous } \\
\text { riparian } \\
\text { forest }\end{array}$ & $\begin{array}{c}\text { Grassy } \\
\text { riparian }\end{array}$ & Prairie & $\begin{array}{c}\text { Upland } \\
\text { deciduous } \\
\text { forest }\end{array}$ & $\begin{array}{c}\text { Rocky } \\
\text { outcrops }\end{array}$ & $\begin{array}{c}\text { Disturbed } \\
\text { areas }\end{array}$ & Aquatic & \\
\hline \multicolumn{11}{|l|}{$\underline{\text { Mammals }}$} \\
\hline Bison & Bison bison & $\mathbf{H}$ & $\mathbf{x}$ & $\mathbf{x}$ & $\mathbf{x}$ & $\mathbf{x}$ & $\mathbf{x}$ & $\mathbf{x}$ & & 1,2 \\
\hline Elliot's Short-tailed Shrew & Blarina hylophaga & $\mathbf{H}$ & & $\mathbf{x}$ & $\mathbf{x}$ & $\mathbf{x}$ & & & & $1,2,3$ \\
\hline Cow & Bos spp. & $\mathbf{H}$ & $\mathbf{x}$ & $\mathbf{x}$ & $\mathbf{x}$ & $\mathbf{x}$ & $\mathbf{x}$ & & & 4 \\
\hline Coyote & Canis latrans & $\mathbf{O}$ & $\mathbf{x}$ & $\mathbf{x}$ & $\mathbf{x}$ & $\mathbf{x}$ & $\mathbf{x}$ & $\mathbf{x}$ & & 1,2 \\
\hline Beaver & Castor canadensis & $\mathbf{H}$ & $\mathbf{x}$ & $\mathbf{x}$ & & & & & $\mathbf{x}$ & 1,2 \\
\hline Hispid Pocket Mouse & Chaetodipus hispidus & $\mathbf{H}$ & & & & & $\mathbf{x}$ & $\mathbf{x}$ & & $1,2,3$ \\
\hline Least Shrew & Cryptotis parva & $\mathrm{C}$ & & & $\mathbf{x}$ & & & $\mathbf{x}$ & & $1,2,3$ \\
\hline Nine-banded Armadillo & Dasypus novemcinctus & $\mathbf{O}$ & $\mathbf{x}$ & $\mathbf{x}$ & $\mathbf{x}$ & $\mathbf{x}$ & $\mathbf{x}$ & $\mathbf{x}$ & & 1 \\
\hline Kerr, Virginia Opossum & Didelphis virginiana & $\mathbf{O}$ & & & $\mathbf{x}$ & & & & & 1,2 \\
\hline Mountain Lion & Felis concolor & $\mathrm{C}$ & $\mathbf{x}$ & $\mathbf{x}$ & $\mathbf{x}$ & $\mathbf{x}$ & $\mathbf{x}$ & & & 1,2 \\
\hline Red Bat & Lasiurus borealis & $\mathbf{I}$ & $\mathbf{x}$ & & & & & & & 1,2 \\
\hline Black-tailed Jack Rabbit & Lepus californicus & $\mathbf{H}$ & & & $\mathbf{x}$ & & & $\mathbf{x}$ & & 1,2 \\
\hline Bobcat & Felis rufus & $\mathrm{C}$ & $\mathbf{x}$ & $\mathbf{x}$ & $\mathbf{x}$ & & & $\mathbf{x}$ & & 1,2 \\
\hline Woodchuck & Marmota monax & $\mathbf{H}$ & $\mathbf{x}$ & & & $\mathbf{x}$ & & & & 2 \\
\hline Striped Skunk & Mephitis mephitis & $\mathbf{O}$ & $\mathbf{x}$ & & & & & $\mathbf{x}$ & & 1,2 \\
\hline Prairie Vole & Microtus ochrogaster & $\mathbf{H}$ & $\mathbf{x}$ & $\mathbf{x}$ & $\mathbf{x}$ & & & $\mathbf{x}$ & & $1,2,3$ \\
\hline Woodland Vole & Microtus pinetorum & $\mathbf{H}$ & & & $\mathbf{x}$ & & & & & $1,2,3$ \\
\hline House Mouse & Mus musculus & $\mathbf{H}$ & & & $\mathbf{x}$ & & & $\mathbf{x}$ & & $1,2,3$ \\
\hline Mink & Mustela vison & $\mathrm{C}$ & $\mathbf{x}$ & $\mathbf{x}$ & & & & & $\mathbf{x}$ & 2 \\
\hline Eastern Woodrat & Neotoma floridana & $\mathbf{H}$ & $\mathbf{x}$ & & $\mathbf{x}$ & $\mathbf{x}$ & $\mathbf{x}$ & $\mathbf{x}$ & & $1,2,3$ \\
\hline Evening Bat & Nycticeius humeralis & I & $\mathbf{x}$ & & & & & & & 1 \\
\hline
\end{tabular}


Table A-1. Master Species List of the Tallgrass Prairie Preserve, OK (Cont.).

\begin{tabular}{|c|c|c|c|c|c|c|c|c|c|c|}
\hline \multirow[b]{2}{*}{ Common name } & \multirow[b]{2}{*}{ Scientific name } & \multirow[b]{2}{*}{$\begin{array}{l}\text { Trophic } \\
\text { level }^{\mathrm{a}}\end{array}$} & \multicolumn{7}{|c|}{ Habitat $^{\mathrm{b}}$} & \multirow[b]{2}{*}{ Source $^{c}$} \\
\hline & & & $\begin{array}{c}\text { Deciduous } \\
\text { riparian } \\
\text { forest }\end{array}$ & $\begin{array}{c}\text { Grassy } \\
\text { riparian }\end{array}$ & Prairie & $\begin{array}{c}\text { Upland } \\
\text { deciduous } \\
\text { forest }\end{array}$ & $\begin{array}{c}\text { Rocky } \\
\text { outcrops }\end{array}$ & $\begin{array}{c}\text { Disturbed } \\
\text { areas }\end{array}$ & Aquatic & \\
\hline \multicolumn{11}{|l|}{ Mammals (cont.) } \\
\hline White Tailed Deer & Odocoileus virginianus & $\mathbf{H}$ & $\mathbf{x}$ & $\mathbf{x}$ & $\mathbf{x}$ & $\mathbf{x}$ & $\mathbf{x}$ & $\mathbf{x}$ & & 1,2 \\
\hline Muskrat & Ondatra zibethicus & $\mathbf{H}$ & $x$ & $\mathbf{x}$ & & & & & $\mathbf{x}$ & 2 \\
\hline Cotton Mouse & Peromyscus gossypinus & $\mathbf{O}$ & $x$ & & & $\mathbf{x}$ & & & & $1,2,3$ \\
\hline White-footed Mouse & Peromyscus leucopus & $\mathbf{O}$ & $\mathbf{x}$ & $\mathbf{x}$ & $\mathbf{x}$ & $\mathbf{x}$ & $x$ & $\mathbf{x}$ & & $1,2,3$ \\
\hline Deer Mouse & Peromyscus maniculatus & $\mathbf{O}$ & & $\mathbf{x}$ & $\mathbf{x}$ & $x$ & $x$ & $\mathbf{x}$ & & $1,2,3$ \\
\hline Raccoon & Procyon lotor & $\mathrm{O}$ & $\mathbf{x}$ & $\mathbf{x}$ & & $\mathbf{x}$ & & & & 1,2 \\
\hline Fulvous Harvest Mouse & $\begin{array}{l}\text { Reithrodontomys } \\
\text { fulvescens }\end{array}$ & $\mathbf{O}$ & $\mathbf{x}$ & $\mathbf{x}$ & $\mathbf{x}$ & & $\mathbf{x}$ & $\mathbf{x}$ & & $1,2,3$ \\
\hline Eastern Harvest Mouse & Reithrodontomys humulis & $\mathbf{O}$ & & & $\mathbf{x}$ & & & & & $1,2,3$ \\
\hline Western Harvest Mouse & $\begin{array}{l}\text { Reithrodontomys } \\
\text { megalotis }\end{array}$ & $\mathbf{O}$ & & & $\mathbf{x}$ & & & & & $1,2,3$ \\
\hline Plains Harvest Mouse & $\begin{array}{l}\text { Reithrodontomys } \\
\text { montanus }\end{array}$ & $\mathbf{O}$ & & $\mathbf{x}$ & $\mathbf{x}$ & & & & & $1,2,3$ \\
\hline Eastern Mole & Scalopus aquaticus & I & $x$ & & & & & & & $1,2,3$ \\
\hline Fox Squirrel & Sciurus niger & $\mathbf{O}$ & $\mathbf{x}$ & & & & & & & 1 \\
\hline Hispid Cotton Rat & Sigmodon hispidus & $\mathbf{H}$ & $\mathbf{x}$ & $\mathbf{x}$ & $\mathbf{x}$ & $\mathbf{x}$ & $\mathbf{x}$ & $\mathbf{x}$ & & $1,2,3$ \\
\hline 13-lined Ground Squirrel & $\begin{array}{l}\text { Spermophilus } \\
\text { tridecimlineatus }\end{array}$ & $\mathbf{O}$ & & & $\mathbf{x}$ & & $\mathbf{x}$ & & & 2 \\
\hline Eastern Cottontail & Sylvilagus floridanus & $\mathbf{H}$ & $x$ & & & $\mathbf{x}$ & $\mathbf{x}$ & $\mathbf{x}$ & & 1 \\
\hline Badger & Taxidea taxus & $\mathrm{C}$ & & & $\mathbf{x}$ & & & $\mathbf{x}$ & & 1,2 \\
\hline Gray Fox & Urocyon cinereoargenteus & $\mathbf{O}$ & $\mathbf{x}$ & & $\mathbf{x}$ & $\mathbf{x}$ & & & & 2 \\
\hline
\end{tabular}


Table A-1. Master Species List of the Tallgrass Prairie Preserve, OK (Cont.).

\begin{tabular}{|c|c|c|c|c|c|c|c|c|c|c|}
\hline \multirow[b]{2}{*}{ Common name } & \multirow[b]{2}{*}{ Scientific name } & \multirow[b]{2}{*}{$\begin{array}{c}\text { Trophic } \\
\text { level }^{\mathrm{a}}\end{array}$} & \multicolumn{7}{|c|}{ Habitat $^{\mathrm{b}}$} & \multirow[b]{2}{*}{ Source $^{c}$} \\
\hline & & & $\begin{array}{c}\text { Deciduous } \\
\text { riparian } \\
\text { forest }\end{array}$ & $\begin{array}{c}\text { Grassy } \\
\text { riparian }\end{array}$ & Prairie & $\begin{array}{l}\text { Upland } \\
\text { deciduous } \\
\text { forest }\end{array}$ & $\begin{array}{c}\text { Rocky } \\
\text { outcrops }\end{array}$ & $\begin{array}{c}\text { Disturbed } \\
\text { areas }\end{array}$ & Aquatic & \\
\hline \multicolumn{11}{|l|}{$\underline{\text { Birds }}$} \\
\hline Blackbird, red-winged & Agelaius phoeniceus & $\mathbf{O}$ & & & & SR & & & & 1,2 \\
\hline Blue jay & Cyanocitta cristata & $\mathbf{O}$ & SR/WR & & & SR/WR & & & & 1,2 \\
\hline Bluebird, eastern & Sialia sialis & $\mathbf{O}$ & SR & & & SR/WR & & & & 1,2 \\
\hline Bluebird, mountain & Sialia currucoides & $\mathbf{O}$ & & & & & WV & & & 1 \\
\hline Bobwhite & Colinus virginianus & $\mathbf{O}$ & SR & & SR & WR & & & & 1,2 \\
\hline Brown thrasher & Toxostoma rufum & $\mathbf{O}$ & & & & SR & SR & & & 1,2 \\
\hline Bunting, indigo & Passerina cyanea & $\mathbf{O}$ & SR & & & SR & & & & 1,2 \\
\hline Bunting, painted & Passerina ciris & $\mathbf{O}$ & & & & & & & & 2 \\
\hline Canada goose & Branta canadensis & $\mathbf{O}$ & & & & & & & & 1,2 \\
\hline Cardinal & Cardinalis cardinalis & $\mathbf{O}$ & WR & & & SRWR & SR & & & 1,2 \\
\hline Catbird & Dumetella carolinensis & $\mathbf{O}$ & & & & SR & SR & & & 2 \\
\hline Chickadee, Carolina & Parus carolinensis & $\mathbf{O}$ & & & & & & & & 1,2 \\
\hline Chimney swift & Chaetura pelagica & $\mathbf{O}$ & & & & & & $\mathbf{x}$ & & 1,2 \\
\hline Chuck-will's-widow & Caprimulgus carolinensis & $\mathbf{O}$ & & & & & & & & 1,2 \\
\hline Coot, American & Fulica americana & $\mathbf{O}$ & & & & & & & & 2 \\
\hline Cormorant, double-crested & Phalacrocorax auritus & $\mathbf{P}$ & & & & & & & & 1,2 \\
\hline Cowbird, brown-headed & Molothrus ater & $\mathbf{O}$ & SR/WR & & SR & SR & SR & & & 1,2 \\
\hline Creeper, brown & Certhia familiaris & $\mathbf{O}$ & & & & & & & & 2 \\
\hline Crow, american & Corvus brachyrhynchos & $\mathbf{O}$ & SR/WR & & & SR/WR & & & & 1,2 \\
\hline Crow, fish & Corvus ossifragus & $\mathbf{O}$ & & & & & & & & 2 \\
\hline Dickcissel & Spiza americana & $\mathbf{O}$ & & & SR & & & & & 1,2 \\
\hline Dove, mourning & Zenaida macroura & $\mathrm{O}$ & & & SR & SR & & & & 1,2 \\
\hline
\end{tabular}


Table A-1. Master Species List of the Tallgrass Prairie Preserve, OK (Cont.).

\begin{tabular}{|c|c|c|c|c|c|c|c|c|c|c|}
\hline \multirow[b]{2}{*}{ Common name } & \multirow[b]{2}{*}{ Scientific name } & \multirow[b]{2}{*}{$\begin{array}{c}\text { Trophic } \\
\text { level }^{\mathrm{a}}\end{array}$} & \multicolumn{7}{|c|}{ Habitat $^{\mathrm{b}}$} & \multirow[b]{2}{*}{ Source } \\
\hline & & & $\begin{array}{l}\text { Deciduous } \\
\text { riparian } \\
\text { forest }\end{array}$ & $\begin{array}{c}\text { Grassy } \\
\text { riparian }\end{array}$ & Prairie & $\begin{array}{l}\text { Upland } \\
\text { deciduous } \\
\text { forest }\end{array}$ & $\begin{array}{c}\text { Rocky } \\
\text { outcrops }\end{array}$ & $\begin{array}{c}\text { Disturbed } \\
\text { areas }\end{array}$ & Aquatic & \\
\hline \multicolumn{11}{|l|}{ Birds (cont.) } \\
\hline Dove, rock & Columba livia & $\mathbf{O}$ & & & & & & $\mathbf{x}$ & & 2 \\
\hline Dowitcher, long-billed & Limnodromus griseus & $\mathbf{O}$ & & & & & & & & 2 \\
\hline Duck, ring-necked & Aythya collaris & $\mathbf{O}$ & & & & & & & & 1,2 \\
\hline Duck, wood & Aix sponsa & $\mathbf{O}$ & SR & & & & & & & 1,2 \\
\hline Eagle, bald & Haliaeetus leucocephalus & C & & & & & & & & 2 \\
\hline Egret, cattle & Bubulcus ibis & $\mathbf{I}$ & & & & & & & & 1,2 \\
\hline Egret, great & Casmerodius albus & $\mathbf{P}$ & & & & & & & & 2 \\
\hline Egret, snowy & Egretta thula & $\mathbf{P}$ & & & & & & & & 2 \\
\hline Falcon, peregrine & Falco peregrinus & C & & & $\mathbf{M}$ & & & & & 2 \\
\hline Flycatcher, Acadian & Empidomax virescens & $\mathbf{I}$ & & & & & & & & 2 \\
\hline Flycatcher, alder & Empidomax alnorum & $\mathbf{I}$ & & & & & & & & 2 \\
\hline Flycatcher, great crested & Myiarchus crinitus & $\mathbf{I}$ & SR & & & SR & & & & 1,2 \\
\hline Flycatcher, least & Empidomax minimus & $\mathbf{I}$ & $\mathbf{M}$ & & & $\mathbf{M}$ & & & & 2 \\
\hline Flycatcher, scissor-tailed & Tyrannus forficatus & $\mathbf{I}$ & & & SV & & & & & 1,2 \\
\hline Flycatcher, willow & Empidomax traillii & $\mathbf{I}$ & & & & $\mathbf{M}$ & & & & 2 \\
\hline Gadwall & Anas strepera & $\mathbf{O}$ & & & & & & & & 2 \\
\hline Gnatcatcher, blue-gray & Polioptila caerulea & $\mathbf{I}$ & SR & & & SR & & & & 1,2 \\
\hline Godwit, Hudsonian & Limosa haemastica & $\mathbf{I}$ & & & & & & & & 2 \\
\hline Goldfinch, American & Carduelis tristis & $\mathbf{O}$ & & & & SR/WR & & & & 2 \\
\hline Grackle, common & Quiscalus quiscula & $\mathbf{O}$ & SV & & & SR & & & & 1,2 \\
\hline Grackle, great-tailed & Quiscalus mexicanus & $\mathbf{O}$ & & & & & & & & 2 \\
\hline Great prairie chicken & Tympanuchus cupido & $\mathbf{O}$ & & & SR & & & & & 1,2 \\
\hline
\end{tabular}


Table A-1. Master Species List of the Tallgrass Prairie Preserve, OK (Cont.).

\begin{tabular}{|c|c|c|c|c|c|c|c|c|c|c|}
\hline \multirow[b]{2}{*}{ Common name } & \multirow[b]{2}{*}{ Scientific name } & \multirow[b]{2}{*}{$\begin{array}{c}\text { Trophic } \\
\text { level }^{\mathrm{a}}\end{array}$} & \multicolumn{7}{|c|}{ Habitat $^{\mathrm{b}}$} & \multirow[b]{2}{*}{ Source } \\
\hline & & & $\begin{array}{l}\text { Deciduous } \\
\text { riparian } \\
\text { forest }\end{array}$ & $\begin{array}{c}\text { Grassy } \\
\text { riparian }\end{array}$ & Prairie & $\begin{array}{l}\text { Upland } \\
\text { deciduous } \\
\text { forest }\end{array}$ & $\begin{array}{c}\text { Rocky } \\
\text { outcrops }\end{array}$ & $\begin{array}{c}\text { Disturbed } \\
\text { areas }\end{array}$ & Aquatic & \\
\hline \multicolumn{11}{|l|}{$\underline{\text { Birds }}$ (cont.) } \\
\hline Grebe, pied-billed & Podilymbus podiceps & $\mathbf{P}$ & & & & & & & & 2 \\
\hline Grosbeak, blue & Guiraca caerulea & $\mathbf{O}$ & & & & SR & & & & 1,2 \\
\hline Gull, Franklin's & Larus pipixcan & $\mathbf{O}$ & & & $\mathbf{M}$ & & & & & 2 \\
\hline Gull, ring-billed & Larus delawarensis & $\mathbf{O}$ & & & $\mathbf{M}$ & & & & & 2 \\
\hline Harrier, northern & Circus cyaneus & C & & & SR/WR & SR & & & & 1,2 \\
\hline Hawk, broad-winged & Buteo platypterus & $\mathrm{C}$ & & & & & & & & 2 \\
\hline Hawk, Cooper's & Accipiter cooperii & C & $\mathbf{M}$ & & & $\mathbf{M}$ & & & & 1,2 \\
\hline Hawk, red-tailed & Buteo jamaicensus & C & SR/WR & & & SR/WR & & & & 1,2 \\
\hline Hawk, rough-legged & Buteo lagopus & C & & & WR & & & & & 2 \\
\hline Hawk, sharp-shinned & Accipiter striatus & $\mathrm{C}$ & $\mathbf{M}$ & & & & & & & 2 \\
\hline Hawk, Swainson's & Buteo swainsoni & C & & & SV & & & & & 2 \\
\hline Heron, black-crowned night & Nycticorax nycticorax & $\mathbf{P}$ & & & & & & & & 2 \\
\hline Heron, great blue & Ardea herodias & $\mathbf{P}$ & & & & & & & & 1,2 \\
\hline Heron, green-backed & Butorides striatus & $\mathbf{P}$ & SR & & & & & & & 2 \\
\hline Heron, little blue & Florida caerulea & $\mathbf{P}$ & & & & & & & & 2 \\
\hline Horned lark & Eremophila alpestris & $\mathbf{O}$ & & & SR & & & & & 1,2 \\
\hline Hummingbird, ruby-throated & Arcjilochus colubris & $\mathbf{O}$ & SR & & & & & & & 2 \\
\hline Junco, dark-eyed & Junco hyemalis & $\mathbf{O}$ & WR & & WR & WR & & & & 2 \\
\hline Kestrel & Falco sparverius & C & & & & M/WR & & & & 1,2 \\
\hline Killdeer & Charadrius vociferous & I & & & & & & $\mathbf{x}$ & & 1,2 \\
\hline Kingbird, eastern & Tyrannus tyrannus & $\mathbf{I}$ & & & SR & SR & & & & 1,2 \\
\hline Kingbird, western & Tyrannus verticalis & $\mathbf{I}$ & & & SV & & & & & 1,2 \\
\hline
\end{tabular}


Table A-1. Master Species List of the Tallgrass Prairie Preserve, OK (Cont.).

\begin{tabular}{|c|c|c|c|c|c|c|c|c|c|c|}
\hline \multirow[b]{2}{*}{ Common name } & \multirow[b]{2}{*}{ Scientific name } & \multirow[b]{2}{*}{$\begin{array}{l}\text { Trophic } \\
\text { level }^{\mathrm{a}}\end{array}$} & \multicolumn{7}{|c|}{ Habitat $^{\text {b }}$} & \multirow[b]{2}{*}{ Source $^{c}$} \\
\hline & & & $\begin{array}{c}\text { Deciduous } \\
\text { riparian } \\
\text { forest }\end{array}$ & $\begin{array}{c}\text { Grassy } \\
\text { riparian }\end{array}$ & Prairie & $\begin{array}{l}\text { Upland } \\
\text { deciduous } \\
\text { forest }\end{array}$ & $\begin{array}{c}\text { Rocky } \\
\text { outcrops }\end{array}$ & $\begin{array}{l}\text { Disturbed } \\
\text { areas }\end{array}$ & Aquatic & \\
\hline \multicolumn{11}{|l|}{$\underline{\text { Birds }}$ (cont.) } \\
\hline Kingfisher, belted & Ceryle alcyon & $\mathbf{P}$ & SR/WR & & & & & & & 1,2 \\
\hline Kinglet, golden-crowned & Regulus satrapa & $\mathbf{I}$ & WR & & & $\mathbf{M}$ & & & & 2 \\
\hline Kite, Mississippi & Ictinia mississippiensis & $\mathrm{C}$ & & & & $\mathbf{M}$ & & & & 2 \\
\hline Loggerhead shrike & Lanius ludovicianus & I & & & SR & SR & & & & 1,2 \\
\hline Mallard & Anas platyrhynchos & $\mathrm{O}$ & & & & & & & & 2 \\
\hline Meadowlark, eastern & Sturnella magna & $\mathbf{O}$ & & & SRWR & & & & & 1,2 \\
\hline Merlin & Falco columbarius & $\mathrm{C}$ & & & $\mathbf{M}$ & & & & & 2 \\
\hline Mockingbird & Mimus polyglottos & $\mathbf{O}$ & & & & & SR & & & 1,2 \\
\hline Nighthawk & Chordeiles minor & I & & & SR & & & & & 1,2 \\
\hline Northern flicker & Colaptes auratus & $\mathbf{I}$ & SR/WR & & & SR/WR & & & & 1,2 \\
\hline Nuthatch, whitebreasted & Sitta carolenensis & $\mathbf{O}$ & SR/WR & & & SR/WR & & & & 1,2 \\
\hline Oriole, Northern & Icterus galbula & $\mathrm{O}$ & $\mathrm{SR}$ & & & SR & & & & 2 \\
\hline Oriole, orchard & Icterus spurius & $\mathbf{O}$ & & & & SR & & & & 1,2 \\
\hline Osprey & Pandion haliaetus & $\mathbf{P}$ & & & & & & & & 1 \\
\hline Owl, barn & Tyto alba & $\mathrm{C}$ & & & & & & & & 2 \\
\hline Owl, barred & Strix varia & $\mathrm{C}$ & SR/WR & & & & & & & 2 \\
\hline Owl, burrowing & Athene cunicularia & $\mathrm{C}$ & & & $\mathbf{M}$ & & & & & 2 \\
\hline Owl, great horned & Bubo virginianus & C & SR/WR & & & SR/WR & & & & 1,2 \\
\hline Owl, screech & Otus asio & $\mathrm{C}$ & WR & & & SR/WR & & & & 2 \\
\hline Owl, short-eared & Asio flammeus & $\mathrm{C}$ & & & $\mathbf{M}$ & & & & & 2 \\
\hline Pheasant, ring-necked & Phasianus colchicus & $\mathbf{O}$ & & & SR & & SR & & & 2 \\
\hline Phoebe, eastern & Savornis phoebe & I & SR & & & SR & & & & 1 \\
\hline
\end{tabular}


Table A-1. Master Species List of the Tallgrass Prairie Preserve, OK (Cont.).

\begin{tabular}{|c|c|c|c|c|c|c|c|c|c|c|}
\hline \multirow[b]{2}{*}{ Common name } & \multirow[b]{2}{*}{ Scientific name } & \multirow[b]{2}{*}{$\begin{array}{c}\text { Trophic } \\
\text { level }^{\mathrm{a}}\end{array}$} & \multicolumn{7}{|c|}{ Habitat $^{\mathrm{b}}$} & \multirow[b]{2}{*}{ Source $^{c}$} \\
\hline & & & $\begin{array}{c}\text { Deciduous } \\
\text { riparian } \\
\text { forest }\end{array}$ & $\begin{array}{c}\text { Grassy } \\
\text { riparian }\end{array}$ & Prairie & $\begin{array}{l}\text { Upland } \\
\text { deciduous } \\
\text { forest }\end{array}$ & $\begin{array}{c}\text { Rocky } \\
\text { outcrops }\end{array}$ & $\begin{array}{l}\text { Disturbed } \\
\text { areas }\end{array}$ & Aquatic & \\
\hline \multicolumn{11}{|l|}{$\underline{\text { Birds }}$ (cont.) } \\
\hline Pintail, northern & Anas acuta & $\mathbf{O}$ & & & & & & & & 2 \\
\hline Plover, lesser golden & Pluvialis squatarola & $\mathbf{O}$ & & & $\mathbf{M}$ & & & & & 2 \\
\hline Poorwill & Phalaenoptilus nuttallii & $\mathbf{I}$ & & & SR & & & & & 2 \\
\hline Purple martin & Progne subis & $\mathbf{I}$ & & & SV & & & & & 1,2 \\
\hline Rail, king & Rallus elegans & $\mathbf{O}$ & & & & & & & & 2 \\
\hline Redhead & Aythya americana & $\mathbf{O}$ & & & & & & & & 1,2 \\
\hline Robin & Turdus migratorius & $\mathbf{O}$ & SR/WR & SR/WR & & SR & & & & 1,2 \\
\hline Sandpiper, semipalmated & Calidris pusilla & $\mathbf{I}$ & & & & & & & & 1 \\
\hline Sandpiper, solitary & Tringa solitaria & $\mathbf{I}$ & & & & & & & & 1,2 \\
\hline Sandpiper, upland & Bartramia longicauda & $\mathbf{I}$ & & & SR & & & & & 1,2 \\
\hline Scaup, lesser & Aythya affinis & $\mathbf{O}$ & & & & & & & & 2 \\
\hline Shoveler, Northern & Anas clypeata & $\mathbf{O}$ & & & & & & & & 2 \\
\hline Snipe & Gallinago gallinago & $\mathbf{I}$ & & & & & & & & 1,2 \\
\hline Sora & Porzana carolina & $\mathbf{O}$ & & & & & & & & 2 \\
\hline Sparrow, American tree & Spizella arborea & $\mathbf{O}$ & WR & & WR & WR & WR & & & 2 \\
\hline Sparrow, chipping & Spizella passerina & $\mathbf{O}$ & $\mathbf{M}$ & & & $\mathbf{M}$ & & & & 1,2 \\
\hline Sparrow, field & Spizella pusilla & $\mathbf{O}$ & & & & SR & & & & 1,2 \\
\hline Sparrow, grasshopper & Ammodramus savannarum & $\mathbf{O}$ & & & & & & & & 1,2 \\
\hline Sparrow, Harris' & Zonotrichia querula & $\mathbf{O}$ & WR & & SR & WR & & & & 2 \\
\hline Sparrow, Henslow's & Ammodramus henslowii & $\mathbf{O}$ & & & SR & & & & & 2 \\
\hline Sparrow, house & Passer domesticus & $\mathbf{O}$ & & & & & & $\mathbf{x}$ & & 1,2 \\
\hline Sparrow, lark & Chondestes grammacus & $\mathrm{O}$ & & & SR & SR & & & & 1,2 \\
\hline
\end{tabular}


Table A-1. Master Species List of the Tallgrass Prairie Preserve, OK (Cont.).

\begin{tabular}{|c|c|c|c|c|c|c|c|c|c|c|}
\hline \multirow[b]{2}{*}{ Common name } & \multirow[b]{2}{*}{ Scientific name } & \multirow[b]{2}{*}{$\begin{array}{c}\text { Trophic } \\
\text { level }^{\mathrm{a}}\end{array}$} & \multicolumn{7}{|c|}{ Habitat $^{\mathrm{b}}$} & \multirow[b]{2}{*}{ Source $^{c}$} \\
\hline & & & $\begin{array}{c}\text { Deciduous } \\
\text { riparian } \\
\text { forest }\end{array}$ & $\begin{array}{c}\text { Grassy } \\
\text { riparian }\end{array}$ & Prairie & $\begin{array}{l}\text { Upland } \\
\text { deciduous } \\
\text { forest }\end{array}$ & $\begin{array}{c}\text { Rocky } \\
\text { outcrops }\end{array}$ & $\begin{array}{c}\text { Disturbed } \\
\text { areas }\end{array}$ & Aquatic & \\
\hline \multicolumn{11}{|l|}{$\underline{\text { Birds }}$ (cont.) } \\
\hline Sparrow, Lincoln's & Melospiza lincolnii & $\mathbf{O}$ & $\mathbf{M}$ & & & $\mathbf{M}$ & & & & 2 \\
\hline Sparrow, savannah & Passerculus sandwichensis & $\mathbf{O}$ & & & $\mathbf{M}$ & & & & & 1,2 \\
\hline Sparrow, song & Melospiza melodia & $\mathbf{O}$ & WR & & & WR & WR & & & 2 \\
\hline Sparrow, vesper & Pooecetes gramineus & $\mathbf{O}$ & & & $\mathbf{M}$ & & & & & 1,2 \\
\hline Sparrow, white-crowned & Zonotrichia leucophrys & $\mathbf{O}$ & $\mathbf{M}$ & & & $\mathbf{M}$ & & & & 2 \\
\hline Sparrow, white-throated & Zonotrichia albicollis & $\mathbf{O}$ & $\mathbf{M}$ & & & $\mathbf{M}$ & & & & 2 \\
\hline Starling & Sturnus vulgaris & $\mathbf{O}$ & SR/WR & SR/WR & & SR/WR & & & & 1,2 \\
\hline Summer tanager & Piranga rubra & $\mathbf{O}$ & SR & & & & & & & 1,2 \\
\hline Swallow, bank & Riparia riparia & $\mathbf{I}$ & & & & & & & & 1 \\
\hline Swallow, barn & Hirundo rustica & $\mathbf{I}$ & & & SV & & & & & 1,2 \\
\hline Swallow, cliff & Hirundo pyrrhonata & $\mathbf{I}$ & & & SV & & & & & 1,2 \\
\hline Swallow, rough-winged & Stelgidopteryx serripennis & $\mathbf{I}$ & SR & & SR & & & & & 1,2 \\
\hline Teal, blue-winged & Anas discors & $\mathbf{H}$ & & & & & & & & 1,2 \\
\hline Teal, green-winged & Anas crecca & $\mathbf{H}$ & & & & & & & & 2 \\
\hline Thrush, wood & Hylocichla mustelina & $\mathbf{O}$ & $\mathbf{M}$ & & & & & & & 2 \\
\hline Towhee, rufous-sided & Pipilo erythrophthalmus & $\mathbf{O}$ & WR & & & SR/WR & & & & 2 \\
\hline Tufted titmouse & Parus inornatus & $\mathbf{O}$ & SR/WR & & & WR & & & & 1,2 \\
\hline Turkey & Meleagris gallopavo & $\mathbf{O}$ & WR & & & & & & & 1,2 \\
\hline Vireo, Bell's & Vireo bellii & $\mathbf{I}$ & & & & & SR & & & 2 \\
\hline Vireo, red-eyed & Vireo olivaceous & $\mathbf{I}$ & SR & & & & & & & 2 \\
\hline Vireo, yellow-throated & Vireo flavifrons & $\mathbf{I}$ & & & & & & & & 1 \\
\hline Vulture, turkey & Cathartes aura & C & & & SV & & & & & 1,2 \\
\hline
\end{tabular}


Table A-1. Master Species List of the Tallgrass Prairie Preserve, OK (Cont.).

\begin{tabular}{|c|c|c|c|c|c|c|c|c|c|c|}
\hline \multirow[b]{2}{*}{ Common name } & \multirow[b]{2}{*}{ Scientific name } & \multirow[b]{2}{*}{$\begin{array}{c}\text { Trophic } \\
\text { level }^{\mathrm{a}}\end{array}$} & \multicolumn{7}{|c|}{ Habitat $^{\mathrm{b}}$} & \multirow[b]{2}{*}{ Source } \\
\hline & & & $\begin{array}{l}\text { Deciduous } \\
\text { riparian } \\
\text { forest }\end{array}$ & $\begin{array}{c}\text { Grassy } \\
\text { riparian }\end{array}$ & Prairie & $\begin{array}{l}\text { Upland } \\
\text { deciduous } \\
\text { forest }\end{array}$ & $\begin{array}{c}\text { Rocky } \\
\text { outcrops }\end{array}$ & $\begin{array}{c}\text { Disturbed } \\
\text { areas }\end{array}$ & Aquatic & \\
\hline \multicolumn{11}{|l|}{ Birds (cont.) } \\
\hline Warbler, black and white & Mniotilta varia & $\mathbf{I}$ & SV & & & SV & & & & 1,2 \\
\hline Warbler, Cape May & Dendroica tigrina & $\mathbf{I}$ & & & & & & & & 2 \\
\hline Warbler, Kentucky & Oporornis formosus & $\mathbf{I}$ & SR & & & & & & & 2 \\
\hline Warbler, Northern parula & Parula americana & $\mathbf{I}$ & & & & & & & & 2 \\
\hline Warbler, yellow & Dendroica petechia & $\mathbf{I}$ & SV & & & SV & SV & & & 2 \\
\hline Warbler, yellow-rumped & Dendroica coronata & $\mathbf{O}$ & $\mathbf{M}$ & & & $\mathbf{M}$ & & & & 2 \\
\hline Waterthrush, Louisiana & Seiurus motacilla & $\mathbf{O}$ & SR & & & & & & & 1,2 \\
\hline Waxwing, cedar & Bombycilla garrulus & $\mathbf{O}$ & $\mathbf{M}$ & & & $\mathbf{M}$ & & & & 2 \\
\hline Whip-poor-will & Caprimulgus vociferus & $\mathbf{I}$ & $\mathbf{M}$ & & & & & & & 2 \\
\hline Widgeon, American & Anas americana & $\mathbf{O}$ & & & & & & & & 2 \\
\hline Wood-pewee, eastern & Contopus virens & $\mathbf{I}$ & SR & & & SR & & & & 1,2 \\
\hline Woodpecker, downy & Picoides pubescens & $\mathbf{I}$ & SR/WR & & & SR/WR & & & & 1,2 \\
\hline Woodpecker, hairy & Picoides villosus & $\mathbf{I}$ & SR/WR & & & SR/WR & & & & 2 \\
\hline Woodpecker, pileated & Dryocopus pileatus & $\mathbf{O}$ & & & & & & & & 1,2 \\
\hline Woodpecker, red-bellied & Melanerpes carolinus & $\mathbf{I}$ & SR/WR & & & SR/WR & & & & 1,2 \\
\hline Woodpecker, red-headed & Melanerpes erythrocephalus & $\mathbf{O}$ & SR/WR & & & SR/WR & & & & 1,2 \\
\hline Wren, Bewick's & Thryomanes bewickii & $\mathbf{I}$ & & & & SR & SR & & & 1,2 \\
\hline Wren, Carolina & Thryothorus ludovicianus & $\mathbf{I}$ & SR/WR & & & & & & & 1,2 \\
\hline Yellow-billed cuckoo & Coccyzus americanus & $\mathbf{I}$ & SR & & & SR & & & & 1,2 \\
\hline Yellowlegs, greater & Tringa melanoleuca & $\mathbf{I}$ & & & & & & & & 2 \\
\hline Yellowlegs, lesser & Tringa flavipes & $\mathbf{I}$ & & & & & & & & 2 \\
\hline Yellowthroat, common & Geothlypis trichas & $\mathbf{I}$ & & & SR & & & & & 1,2 \\
\hline
\end{tabular}


Table A-1. Master Species List of the Tallgrass Prairie Preserve, OK (Cont.).

\begin{tabular}{|c|c|c|c|c|c|c|c|c|c|c|}
\hline \multirow[b]{2}{*}{ Common name } & \multirow[b]{2}{*}{ Scientific name } & \multirow[b]{2}{*}{$\begin{array}{l}\text { Trophic } \\
\text { level }^{\mathrm{a}}\end{array}$} & \multicolumn{7}{|c|}{ Habitat $^{\mathrm{b}}$} & \multirow[b]{2}{*}{ Source $^{c}$} \\
\hline & & & $\begin{array}{c}\text { Deciduous } \\
\text { riparian } \\
\text { forest }\end{array}$ & $\begin{array}{c}\text { Grassy } \\
\text { riparian }\end{array}$ & Prairie & $\begin{array}{c}\text { Upland } \\
\text { deciduous } \\
\text { forest }\end{array}$ & $\begin{array}{c}\text { Rocky } \\
\text { outcrops }\end{array}$ & $\begin{array}{l}\text { Disturbed } \\
\text { areas }\end{array}$ & Aquatic & \\
\hline \multicolumn{11}{|l|}{ Herptiles-turtles } \\
\hline Midland Smooth Softshell & Trionyx muticus & $\mathbf{O}$ & & & & & & & $x$ & 2 \\
\hline Mississippi Map Turtle & Graptemys kohnii & $\mathbf{O}$ & & & & & & & $\mathbf{x}$ & 2 \\
\hline Ornate Box Turtle & Terrapene ornata & $\mathbf{O}$ & & & $x$ & & & & & 2 \\
\hline Red-eared Turtle & Trachemys scripta & $\mathbf{O}$ & & & & & & & $\mathbf{x}$ & 2 \\
\hline Snapping Turtle, common & Chelydra serpentina & $\mathbf{O}$ & & & & & & & $\mathbf{x}$ & 2 \\
\hline Spiny Softshell Turtle & Trionyx spiniferus & $\mathbf{O}$ & & & & & & & $\mathbf{x}$ & 2 \\
\hline Stinkpot & Stermotherus odoratus & $\mathbf{O}$ & & & & & & & $\mathbf{x}$ & 2 \\
\hline Three-toed Box Turtle & Terrapene carolina & $\mathbf{O}$ & $\mathbf{x}$ & & & $\mathbf{x}$ & & & & 2 \\
\hline \multicolumn{11}{|l|}{ Herptiles-lizards } \\
\hline Broadhead Skink & Eumeces laticeps & $\mathbf{I}$ & $\mathbf{x}$ & & & $\mathbf{x}$ & & & & 2 \\
\hline Eastern Collared Lizard & Crotaphytus collaris & $\mathrm{C}$ & & & & & $\mathbf{x}$ & & & 2 \\
\hline Fence Lizard & Sceloporus undulatus & $\mathbf{I}$ & & & & $\mathbf{x}$ & $\mathbf{x}$ & & & 2 \\
\hline Five-lined Skink & Eumeces fasciatus & $\mathbf{I}$ & $\mathbf{x}$ & & & $\mathbf{x}$ & & & & 2 \\
\hline Great Plains Skink & Eumeces obsoletus & I & & & $\mathbf{x}$ & & & & & 2 \\
\hline Ground Skink & Scincella lateralis & $\mathbf{I}$ & $\mathbf{x}$ & & & $\mathbf{x}$ & & & & 2 \\
\hline Six-lined Racerunner & Cnemidophorus sexlineatus & I & & & $\mathbf{x}$ & & $\mathbf{x}$ & & & 2 \\
\hline Southern Prairie Skink & Eumeces septentrionalis & I & & & $\mathbf{x}$ & & $\mathbf{x}$ & & & 2 \\
\hline Texas Horned Lizard & Phrynosoma cornutum & I & & & & & & & & 2 \\
\hline Western Glass Lizard & Ophisaurus attenuatus & $\mathrm{C}$ & & & $\mathbf{x}$ & $\mathbf{x}$ & & & & 2 \\
\hline
\end{tabular}


Table A-1. Master Species List of the Tallgrass Prairie Preserve, OK (Cont.).

\begin{tabular}{|c|c|c|c|c|c|c|c|c|c|c|}
\hline \multirow[b]{2}{*}{ Common name } & \multirow[b]{2}{*}{ Scientific name } & \multirow[b]{2}{*}{$\begin{array}{l}\text { Trophic } \\
\text { level }^{\mathrm{a}}\end{array}$} & \multicolumn{7}{|c|}{ Habitat $^{\mathrm{b}}$} & \multirow[b]{2}{*}{ Source } \\
\hline & & & $\begin{array}{l}\text { Deciduous } \\
\text { riparian } \\
\text { forest }\end{array}$ & $\begin{array}{c}\text { Grassy } \\
\text { riparian }\end{array}$ & Prairie & $\begin{array}{c}\text { Upland } \\
\text { deciduous } \\
\text { forest }\end{array}$ & $\begin{array}{c}\text { Rocky } \\
\text { outcrops }\end{array}$ & $\begin{array}{c}\text { Disturbed } \\
\text { areas }\end{array}$ & Aquatic & \\
\hline \multicolumn{11}{|l|}{ Herptiles-snakes } \\
\hline Black Ratsnake & Elaphe obseleta & C & & & $\mathbf{x}$ & $\mathbf{x}$ & $\mathbf{x}$ & $\mathbf{x}$ & & 2 \\
\hline Broad-banded Copperhead & Agkistrodon contortrix & C & & & $\mathbf{x}$ & $\mathbf{x}$ & & & & 2 \\
\hline Brown Snake & Storeria dekayi & $\mathbf{I}$ & $\mathbf{x}$ & $\mathbf{x}$ & $\mathbf{x}$ & $\mathbf{x}$ & $\mathbf{x}$ & $\mathbf{x}$ & & 2 \\
\hline Bullsnake & Pituophis melanoleucus & $\mathrm{C}$ & & & $\mathbf{x}$ & & & & & 2 \\
\hline Central Plains Milk Snake & Lampropeltis triangulum & $\mathrm{C}$ & & $\mathbf{x}$ & $\mathbf{x}$ & $\mathbf{x}$ & $\mathbf{x}$ & & & 2 \\
\hline Coachwhip & Masticophis flagellum & $\mathrm{C}$ & & & $\mathbf{x}$ & & $\mathbf{x}$ & & & 2 \\
\hline Common Garter Snake & Thamnophis sirtalis & C & $\mathbf{x}$ & & & $\mathbf{x}$ & & & $\mathbf{x}$ & 2 \\
\hline Diamond-back Water Snake & Nerodia rhombifera & $\mathbf{P}$ & & & & & & & $\mathbf{x}$ & 2 \\
\hline Eastern Hognose Snake & Heterodon platyrhinos & $\mathrm{C}$ & $\mathbf{x}$ & & & $\mathbf{x}$ & & & & 2 \\
\hline Flathead Snake & Tantilla gracilis & $\mathbf{I}$ & & & & & $\mathbf{x}$ & & & 2 \\
\hline Gragham's Crayfish Snake & Regina grahamii & $\mathbf{P}$ & & & & & & & $\mathbf{x}$ & 2 \\
\hline Great Plains Ratsnake & Elaphe guttata & C & & & $\mathbf{x}$ & $\mathbf{x}$ & $\mathbf{x}$ & & & 2 \\
\hline Ground Snake & Sonora semiannulata & I & & & & & $\mathbf{x}$ & & & 2 \\
\hline Lined Snake & Tropidoclonium lineatum & I & & & $\mathbf{x}$ & & & $\mathbf{x}$ & & 2 \\
\hline Massasauga & Sistrurus catenatus & $\mathrm{C}$ & $\mathbf{x}$ & & $\mathbf{x}$ & & & & & 2 \\
\hline Plain-bellied Water Snake & Nerodia erythrogaster & $\mathbf{P}$ & & & & & & & $\mathbf{x}$ & 2 \\
\hline Prairie Kingsnake & Lampropeltis calligaster & C & & & $\mathbf{x}$ & & & & & 2 \\
\hline Ringneck Snake & Diadophis punctatus & $\mathrm{C}$ & & & & & & & & 2 \\
\hline Rough Earth Snake & Virginia striatula & $\mathbf{I}$ & & & & & & & & 2 \\
\hline Rough Green Snake & Opheodrys aestivus & I & $\mathbf{x}$ & & & & & & & 2 \\
\hline Speckled Kingsnake & Lampropeltis getulus & C & & & & $\mathbf{x}$ & & & & 2 \\
\hline Timber Rattlesnake & Crotalus horridus & $\mathrm{C}$ & & & & $\mathbf{x}$ & $\mathbf{x}$ & & & 2 \\
\hline Western Ribbon Snake & Thamnophis proximus & C & $\mathbf{x}$ & $\mathbf{x}$ & & & & & $\mathbf{x}$ & 2 \\
\hline Yellowbelly Racer & Coluber constrictor & C & & & & $\mathbf{x}$ & & & & 2 \\
\hline
\end{tabular}

01-01/ERD TGP:TC:rtd 
Table A-1. Master Species List of the Tallgrass Prairie Preserve, OK (Cont.).

\begin{tabular}{|c|c|c|c|c|c|c|c|c|c|c|}
\hline \multirow[b]{2}{*}{ Common name } & \multirow[b]{2}{*}{ Scientific name } & \multirow[b]{2}{*}{$\begin{array}{l}\text { Trophic } \\
\text { level }^{\mathrm{a}}\end{array}$} & \multicolumn{7}{|c|}{ Habitat $^{b}$} & \multirow[b]{2}{*}{ Source $^{c}$} \\
\hline & & & $\begin{array}{l}\text { Deciduous } \\
\text { riparian } \\
\text { forest }\end{array}$ & $\begin{array}{l}\text { Grassy } \\
\text { riparian }\end{array}$ & Prairie & $\begin{array}{c}\text { Upland } \\
\text { deciduous } \\
\text { forest }\end{array}$ & $\begin{array}{c}\text { Rocky } \\
\text { outcrops }\end{array}$ & $\begin{array}{l}\text { Disturbed } \\
\text { areas }\end{array}$ & Aquatic & \\
\hline \multicolumn{11}{|l|}{ Herptiles - frogs and toads } \\
\hline Blanchard's Cricket Frog & Acris crepitans blanchardi & $\mathbf{I}$ & & & & & & & $\mathbf{x}$ & 2 \\
\hline Bull Frog & Rana catesbeiana & $\mathrm{C}$ & $\mathbf{x}$ & $\mathbf{x}$ & & & & & $\mathbf{x}$ & 2 \\
\hline Cope's Tree Frog & Hyla chrysoscelis & $\mathbf{I}$ & $\mathbf{x}$ & & & & & & & 2 \\
\hline Crawfish Frog & Rana areolata & $\mathrm{C}$ & $\mathbf{x}$ & $\mathbf{x}$ & $\mathbf{x}$ & & & & $\mathbf{x}$ & 2 \\
\hline Dwarf American Toad & Bufo americanus & $\mathbf{I}$ & $\mathbf{x}$ & $\mathbf{x}$ & $\mathbf{x}$ & & & $\mathbf{x}$ & & 2 \\
\hline Gray Tree Frog & Hyla versicolor & $\mathbf{I}$ & $\mathbf{x}$ & & & $\mathbf{x}$ & & & & 2 \\
\hline $\begin{array}{l}\text { Great Plains Narrowmouth } \\
\text { Toad }\end{array}$ & Gastrophryne olivacea & $\mathbf{I}$ & $\mathbf{x}$ & $\mathbf{x}$ & $\mathbf{x}$ & & $\mathbf{x}$ & & & 2 \\
\hline Plains Leopard Frog & Rana blairi & $\mathbf{I}$ & $\mathbf{x}$ & $\mathbf{x}$ & $\mathbf{x}$ & & & & $\mathbf{x}$ & 2 \\
\hline Southern Leopard Frog & Rana utricularia & $\mathbf{I}$ & $\mathbf{x}$ & $\mathbf{x}$ & $\mathbf{x}$ & & & & $\mathbf{x}$ & 2 \\
\hline Strecker's Chorus Frog & Pseudacris streckeri & $\mathbf{I}$ & & & $\mathbf{x}$ & & & & & 2 \\
\hline Western Chorus Frog & Pseudacris triseriata & I & $\mathbf{x}$ & $\mathbf{x}$ & $\mathbf{x}$ & & & & & 2 \\
\hline Woodhouse's Toad & Bufo woodhousei & I & & & & & & & & 2 \\
\hline
\end{tabular}

a Trophic levels are as follows: $\mathrm{C}=$ carnivore; $\mathrm{H}=$ herbivore; $\mathrm{I}=$ invertivore; $\mathrm{O}=$ omnivore; $\mathrm{P}=$ piscivore.

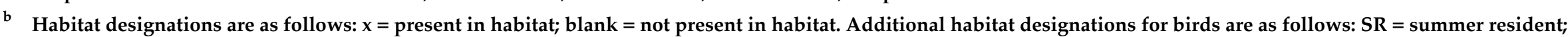
$\mathrm{WR}=$ winter resident; $\mathrm{SV}=$ summer visitor; $\mathrm{WV}=$ winter visitor; $\mathrm{M}=$ migrant.

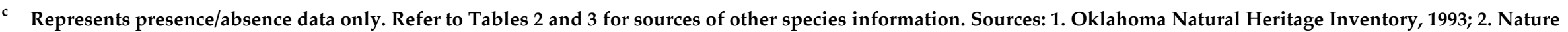
Conservancy, 1996; 3. Payne and Caire, 1999; 4. Hamilton, 1996. 


\section{Appendix B}

\section{Partial List of Animal Species of the Aquatic Systems at the Tallgrass Prairie Preserve, OK}


Table B-1. Partial list of animal species of the acquatice systems at the Tallgrass Prairie Preserve, OK.

\begin{tabular}{|c|c|c|c|}
\hline Common name & Scientific name & Trophic level $^{\mathrm{a}}$ & Source $^{b}$ \\
\hline \multicolumn{4}{|l|}{ Mammals } \\
\hline Beaver & Castor canadensis & $\mathbf{H}$ & $1,2,6$ \\
\hline Mink & Mustela vison & $\mathrm{C}$ & 2,6 \\
\hline Muskrat & Ondatra zibethicus & $\mathbf{H}$ & 2,6 \\
\hline \multicolumn{4}{|l|}{$\underline{\text { Birds }}$} \\
\hline Cormorant, double-crested & Phalacrocorax auritus & $\mathbf{P}$ & $1,2,7$ \\
\hline Egret, great & Casmerodius albus & $\mathbf{P}$ & 2,7 \\
\hline Egret, snowy & Egretta thula & $\mathbf{P}$ & 2,7 \\
\hline Grebe, pied-billed & Podilymbus podiceps & $\mathbf{P}$ & 2,7 \\
\hline Heron, black-crowned night & Nycticorax nycticorax & $\mathbf{P}$ & 2,7 \\
\hline Heron, great blue & Ardea herodias & $\mathbf{P}$ & $1,2,7$ \\
\hline Heron, green-backed & Butorides striatus & $\mathbf{P}$ & 2,7 \\
\hline Heron, little blue & Florida caerulea & $\mathbf{P}$ & 2,7 \\
\hline Kingfisher, belted & Ceryle alcyon & $\mathbf{P}$ & $1,2,7$ \\
\hline Osprey & Pandion haliaetus & $\mathbf{P}$ & 1,7 \\
\hline \multicolumn{4}{|l|}{$\underline{\text { Herptiles-turtles }}$} \\
\hline Midland Smooth Softshell & Trionyx muticus & $\mathbf{O}$ & 2,4 \\
\hline Mississippi Map Turtle & Graptemys kohnii & $\mathbf{O}$ & 2,4 \\
\hline Red-eared Turtle & Trachemys scripta & $\mathbf{O}$ & 2,4 \\
\hline Snapping Turtle, common & Chelydra serpentina & $\mathbf{O}$ & 2,4 \\
\hline Spiny Softshell Turtle & Trionyx spiniferus & $\mathbf{O}$ & 2,4 \\
\hline Stinkpot & Stermotherus odoratus & $\mathbf{O}$ & 2,4 \\
\hline \multicolumn{4}{|l|}{ Herptiles-snakes } \\
\hline Common Garter Snake & Thamnophis sirtalis & $\mathbf{C}$ & 2,4 \\
\hline Diamond-back Water Snake & Nerodia rhombifera & $\mathbf{P}$ & 2,4 \\
\hline Gragham's Crayfish Snake & Regina grahamii & $\mathbf{P}$ & 2,4 \\
\hline Plain-bellied Water Snake & Nerodia erythrogaster & $\mathbf{P}$ & 2,4 \\
\hline Western Ribbon Snake & Thamnophis proximus & $\mathbf{C}$ & 2,4 \\
\hline
\end{tabular}


Table B-1. Partial list of animal species of the acquatice systems at the Tallgrass Prairie Preserve, OK (Cont.).

\begin{tabular}{llcc}
\multicolumn{1}{c}{ Common name } & \multicolumn{1}{c}{ Scientific name } & Trophic level $^{\mathrm{a}}$ & Source $^{\mathrm{b}}$ \\
\hline Herptiles-frogs and toads & & & \\
Blanchard's Cricket Frog & Acris crepitans blanchardi & I & 2,4 \\
Bull Frog & Rana catesbeiana & C & 2,4 \\
Crawfish Frog & Rana areolata & C & 2,4 \\
Plains Leopard Frog & Rana blairi & I & 2,4 \\
Southern Leopard Frog & Rana utricularia & I & 2,5 \\
\hline \hline
\end{tabular}

a Trophic levels are as follows: $\mathrm{C}=$ carnivore; $\mathrm{H}=$ herbivore; $\mathrm{I}=$ invertivore; $\mathrm{O}=$ omnivore; $\mathrm{P}=$ piscivore.

b Indicates source for presence/absence and aquatic character. Sources: 1. Oklahoma Natural Heritage Inventory, 1993; 2. Nature Conservancy, 1996; 3. Coppedge and Shaw, 1998; 4. INHS, 1998; 5. Bockstanz and Cannatella, 2000; 6. Myers et al., 1998; 7. Peterson, 1980. 


\section{Appendix C}

Areas of Further Research

C-1 Develop Response Guilds

C-2 Expand Species Information

C-3 Include Temporal Variations

C-4 Address Issues of Spatial Scale and Resolution

C-5 Utilize Statistical Techniques

C-6 Explicitly Examine Ecosystem Dynamics

C-7 References 


\section{Appendix C}

\section{Areas of Further Research}

Depending upon the use of this trophic model, and the direction of future efforts relative to the larger project, several areas of further research may be appropriate.

\section{C-1. Develop "Response Guilds"}

Rather than divide guilds according to food consumption, it may be expedient to divide species on the basis of response to disturbance. This type of guild has been referred to alternately as a response guild (Wilson, 1999) or a management guild (Simberloff and Dayan, 1991). The alpha guilds used in this study, because of similar taxonomy, already offer some insight into response to disturbance; however, an explicit analysis would be more robust. This would allow the selection of endpoint species to provide increasingly consistent results when these species are used as indicators for the results of disturbance from contaminant spills. Such an undertaking may be more challenging, as response to disturbance, for many species, has been poorly studied compared with diet (Simberloff and Dayan, 1991).

\section{C-2. Expand Species Information}

As mentioned, this trophic model does not address issues such as population density of predators, quantity of prey consumed, ability to feed outside preferred resource classes, strictness of habitat requirements, and the portion or life-phase of prey consumed. All of this information may have significant bearing on community dynamics and the ability to use a particular species as an endpoint. Depending upon the level of resolution desired, increasing the amount of information that is incorporated into the trophic model may be appropriate.

Several key processes have also been neglected. First, symbiotic associations between mycorrhiza and plants are ubiquitous, and important in tallgrass prairie plant populations (Hetrick and Bloom, 1983), as has been documented at the Konza Prairie LTER (see Hartnett and Fay, 1998). Disturbances such as soil contamination from oil or brine, as well as other temporal variations and disturbance events, could significantly affect the mycorrhiza community, with impacts on plant diversity, primary productivity, and bottom-up effects on higher trophic levels. Second, the issues of disease and parasitism have not been considered; again, these could alter community dynamics. Finally, decomposers have not been granted a comprehensive treatment. However, Schoener (1989) asserts that decomposers are relatively isolated in most terrestrial food webs, and that their omission, therefore, is relatively unlikely to affect conclusions about food web interactions. 


\section{C-3. Include Temporal Variations}

Disturbance events and cycles (including adjacent land uses), climatic variation, succession, fire, grazing, changes in management of the preserve, and intrinsic population dynamics may all play significant roles in structuring both community and ecosystem structure and function at the TPP (Collins, 1990; ONHI, 1993). In particular, the fire and grazing regimes at the preserve maintained by the Nature Conservancy represent the restoration of key disturbance cycles, the effects of which may have just begun. These two key components are thought to ultimately control the structure of the tallgrass prairie community (ONHI, 1993; Hamilton, 1996). By modeling the TPP system over a longer, specified time period, and incorporating these temporal issues into the analysis, more insight into the impacts of oil and brine contamination over time could potentially be gained.

\section{C-4. Address Issues of Spatial Scale and Resolution}

Several spatial issues may be relevant. To begin with, the beta guilds essentially treat the preserve as two-dimensional. Indeed, prairie ecosystems may be effectively regarded as twodimensional until the spatial scale is very small (Knapp et al., 1998). However, threedimensional aspects may be relevant in the forested areas of the TPP, and may also be important in the prairie guild when studying smaller animals such as insects or rodents. Many of these species interact with the TPP as a three-dimensional system by digging burrows and tunnels in which they store food, nest, and otherwise alter the underground ecosystem, creating small-scale disturbance and microsites for plant colonization and establishment (Hartnett and Fay, 1998). Above the surface, issues such as feeding height may be important to plant community structure, and even in the prairie, differences between the "canopy" and "understory" could be significant. Zimmerman (1993) has divided bird species into guilds based on nesting and feeding height in forested systems at the Konza LTER.

At a larger scale, topographic effects may be very important, as this generates a gradient upon which many (primarily plant) species ordinate. This could likely be addressed by geographic information systems (GIS) analysis using alpha and beta guilds.

Finally, the preserve boundaries may not represent the entire sphere of influence upon the TPP community. Typically, food webs do not neatly compartmentalize into independent units along spatial or temporal boundaries (Pimm, 1982). Species with large home ranges, such as birds or large mammals, may cause the effective boundary of the food web at the TPP to become much larger, having effects that are difficult to predict. Further, larger disturbances, such as climatic effects or adjacent land uses, may affect the community structure and function. Depending upon magnitude of influence, it may be useful to evaluate and incorporate these factors into the trophic model.

\section{C-5. Utilize Statistical Techniques}

Statistical techniques to divide species into guilds, and delineate relationships between and among these guilds, offer a method to ensure that the community structure and function found at the TPP is an empirical rather than a theoretical construct. This method for dividing guilds has been used in efforts such as the designation of intrinsic guilds, in which a statistical test is used 
to determine if members of alpha guilds tend to exclude each other in the real community (Wilson, 1999). Such an increasingly data- and analysis-intensive approach may be appropriate, depending on the final use of the trophic model; it may be particularly useful for analysis of endpoint species and the interaction strengths between the species in the trophic pathways that they represent.

\section{C-6. Explicitly Examine Ecosystem Dynamics}

Finally, use of a trophic model may not be sufficiently comprehensive to fully understand the TPP ecosystem. Community structure and function may not always serve as a reliable proxy for ecosystem structure or function. Ecosystem management is a concept that is growing in popularity, and ecosystem approaches may prove to be extremely useful for evaluating the impacts of contaminant spills at the TPP. DeAngelis (1992) and others have performed extensive work linking community function to ecosystem function by examining nutrient and energy flows associated with trophic relationships, and adding abiotic fractions to the food web. Other important facets to an ecosystem analysis include the identification of key disturbances and driving variables, legacies of past human or natural disturbance, and changes in spatial mosaics over time. Such an analysis at the TPP could critically increase our understanding of the impact of oil and brine spills on ecosystem structure and function, and how this might relate to changes in community structure and function. Several different conceptual frameworks, such as the Legacy Framework (Vogt et al. in revision), provide relatively simple methods of ecosystem evaluation. GIS could also be used in conjunction with such an analysis as an effective platform for generating an ecosystem evaluation.

\section{C-7. References}

Collins, S.L. 1990. "Patterns of community structure during succession in tallgrass prairie," Journal of the Torrey Botanical Club 117, 397-408.

DeAngelis, D.L. 1992. Dynamics of nutrient cycling and food webs (Chapman and Hall, London).

Hamilton, R.G. 1996. "Using fire and bison to restore a functional tallgrass prairie landscape," Transactions of the $61^{\text {st }}$ North American Wildlife and Natural Resources Conference. Wildlife Management Institute, New York, NY.

Hartnett, D.C., and P.A. Fay. 1998. "Plant populations: patterns and processes," in Grassland Dynamics: long-term ecological research in the tallgrass prairie, A.K Knapp, J.M. Briggs, D.C. Harnett, and S.L. Collins, Eds. (Oxford University Press, Oxford).

Hetrick, B.A.D., and J. Bloom. 1983. "Vesicular-arbuscular mycorrhizal fungi associated with native tall grass prairie and cultivated winter wheat," Canadian Journal of Botany 66, 2140-2146.

Knapp, A.K., J.M. Briggs, D.C. Hartnett, and S.L. Collins, Eds. 1998. Grassland Dynamics: long-term ecological research in the tallgrass prairie (Oxford University Press, Oxford).

Oklahoma Natural Heritage Inventory (ONHI). 1993. Part II. Species Inventory for Significant Species at the Tallgrass Prairie Preserve (Oklahoma Biological Survey, Norman, OK). 
Pimm, S. L. 1982. Food webs (Chapman and Hall, London).

Schoener, T.W. 1989. "Food webs from the small to the large," Ecology 70, 1559-1589.

Simberloff, D., and T. Dayan. 1991. "The guild concept and the structure of ecological communities," Annual Review of Ecological Systematics 22, 115-143.

Vogt, K.A., P.A. Palmiotto, A. Fanzeres, M. Tyrrell, D.J. Vogt, P. Wargo, J. Berry, T. PatelWeynand, B. Larson, K.H. Johnson, E. Cuadrado, J. Coty (in revision), "The legacy framework: a new integrative ecosystem framework to evaluate trade-offs and risks of natural resource uses," Ecosystem Health.

Wilson, J.B. 1999. "Guilds, functional types and ecological groups," Oikos 86, 507-522.

Zimmerman, J.L. 1993. The Birds of Konza: the Avian Ecology of the Tallgrass Prairie (University of Kansas Press, Lawrence, KS). 


\begin{abstract}
Appendix D
References Used for Habitat Preference of Species at the Tallgrass Prairie Preserve, OK
\end{abstract}




\section{Appendix D}

\section{References used for Habitat Preference of Species at the Tallgrass Prairie Preserve}

Bockstanz, L.M., and D.C. Cannatella. 2000. Herps of Texas. http://www.zo.utexas.edu/research/txherps/

Cossel, Jr., J. 1998. "Sonora semiannulata (Western Ground Snake)," in Digital Atlas of Idaho -Version 1.01. http://imnh.isu.edu/digitalatlas/

Finck, E.J., D.W. Kaufman, G.A. Kaufman, S.K. Gurtz, B.K. Clark, L.J. Mclellan, and B.S. Clark. 1986. "Mammals of the Konza Prairie Research Natural Area, Kansas." Prairie Naturalist 18, 153-166.

Illinois Natural History Survey (INHS). 1998. INHS Amphibian and Reptile Collection. http://www.inhs.uiuc.edu/cbd/herpdist/species

LeClere, J. 2000. Reptiles and Amphibians of Minnesota. http://216.219.214.109/MinnesotaHerpetology/index.html

McMillan, B.R. and Kaufman, D.W. 1994. "Differences in use of interspersed woodland and grassland by small mammals in Northeastern Kansas," Prairie Naturalist 26, 107-116.

McMillan, B.R., D.W. Kaufman, G.A. Gaufman, and R.S. Matlack. 1997. "Mammals of the Konza Prairie: new observations and an updated species list." Prairie Naturalist 29, 263-272.

Myers, P., C.S. Parr, R. Espinosa, and T. Jones, Eds. 2000. The animal diversity web. http://animaldiversity.ummz.umich.edu/

Payne, T, and W. Caire. 1999. Species diversity of small mammals in the Tallgrass Prairie Preserve, Osage County, Oklahoma, in Proceedings of the Oklahoma Academy of Science 79, 51-59.

Zimmerman, J.L. 1993. The Birds of Konza: the Avian Ecology of the Tallgrass Prairie. University of Kansas Press, Lawrence, KS. 


\section{Appendix E \\ Trophic Pathways at the Tallgrass Prairie Preserve, OK}




\section{Appendix E}

\section{Trophic Pathways at the Tallgrass Prairie Preserve, Oklahoma.}

All possible trophic pathways are traced, from basal species to top predator. $a$. through $c$. show trophic pathways beginning with aboveground invertebrates; $d$. through $f$. show trophic pathways beginning with belowground invertebrates; $g$. shows trophic pathways beginning with small herbivorous mammals; $h$. shows trophic pathways beginning with large herbivorous mammals; $i$. shows trophic pathways beginning with large omnivorous mammals; $j$. shows trophic pathways beginning with small herbivorous mammals; $k$. shows pathways beginning with omnivorous birds; $l$. shows trophic pathways beginning with omnivorous herptiles; $m$. shows trophic pathways beginning with raptors; $n$. shows trophic pathways beginning with fossorial invertivorous mammals.

a.

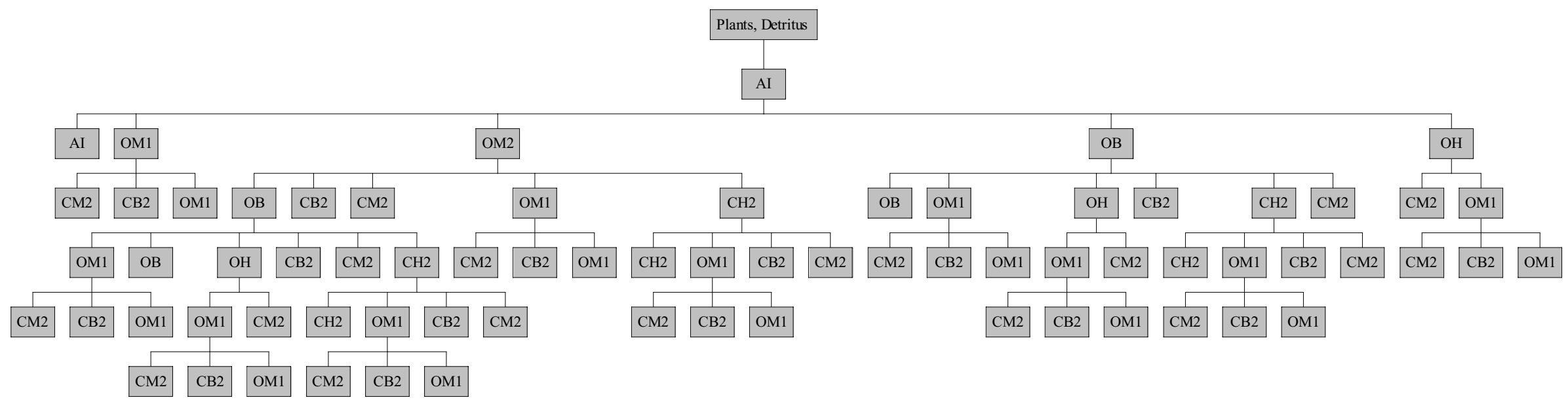


b.

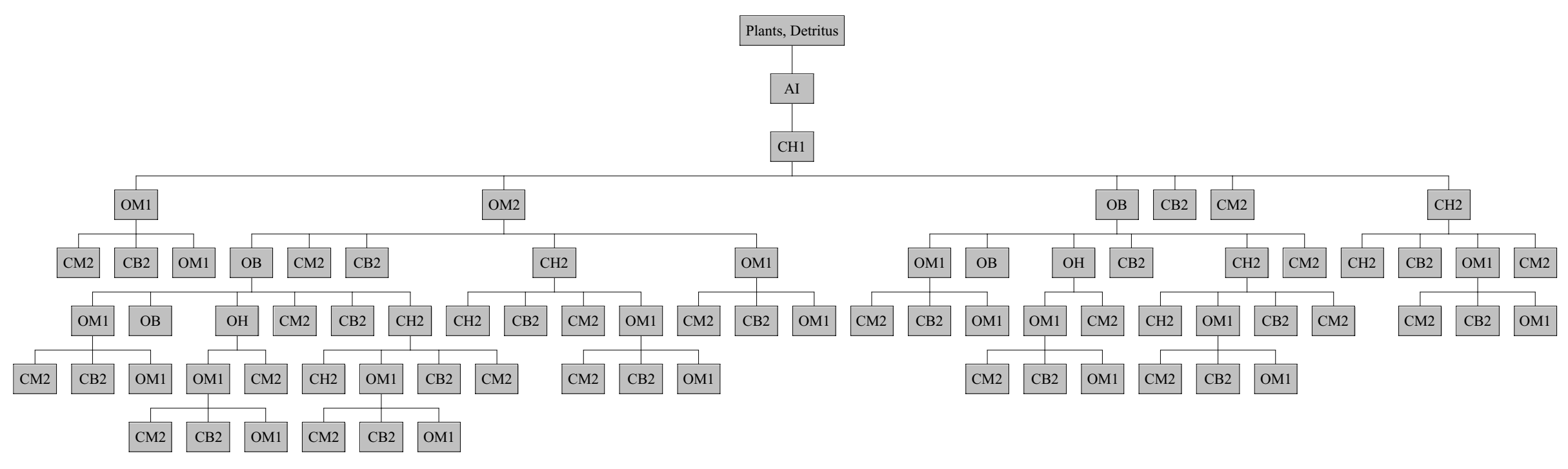


c.

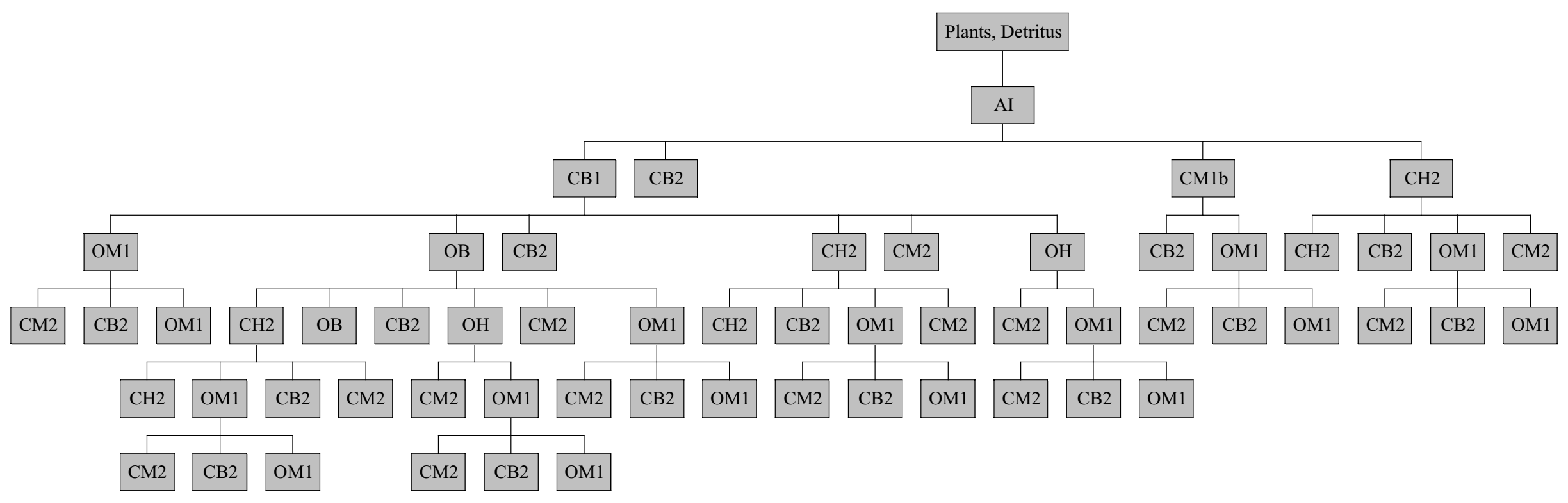


d.

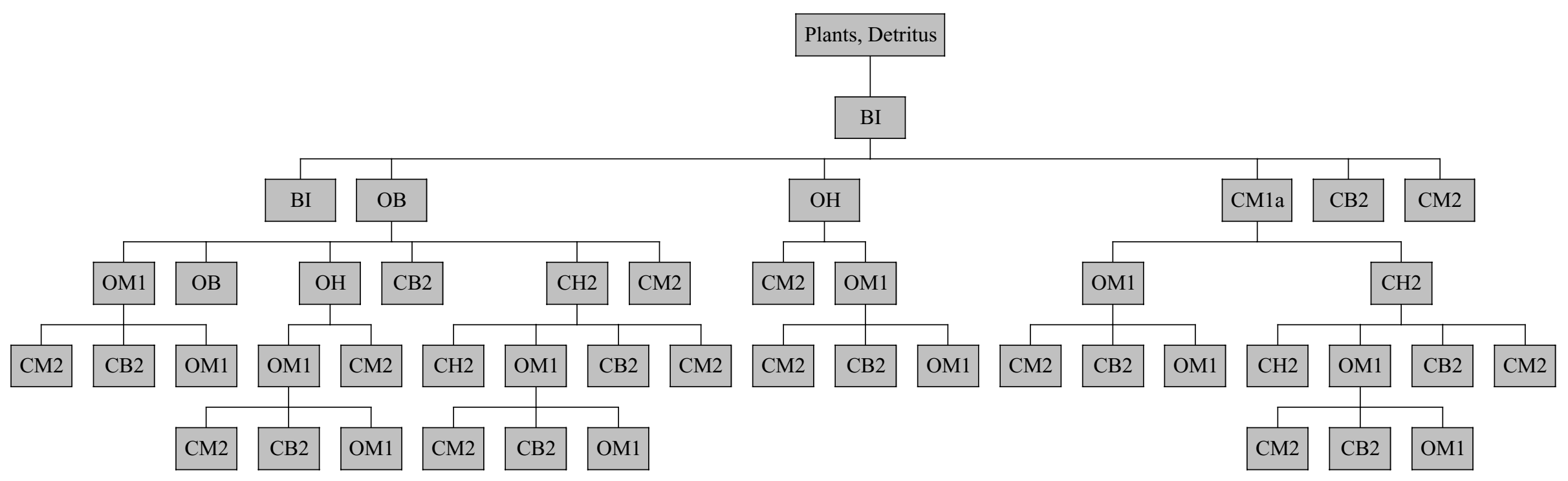


e.

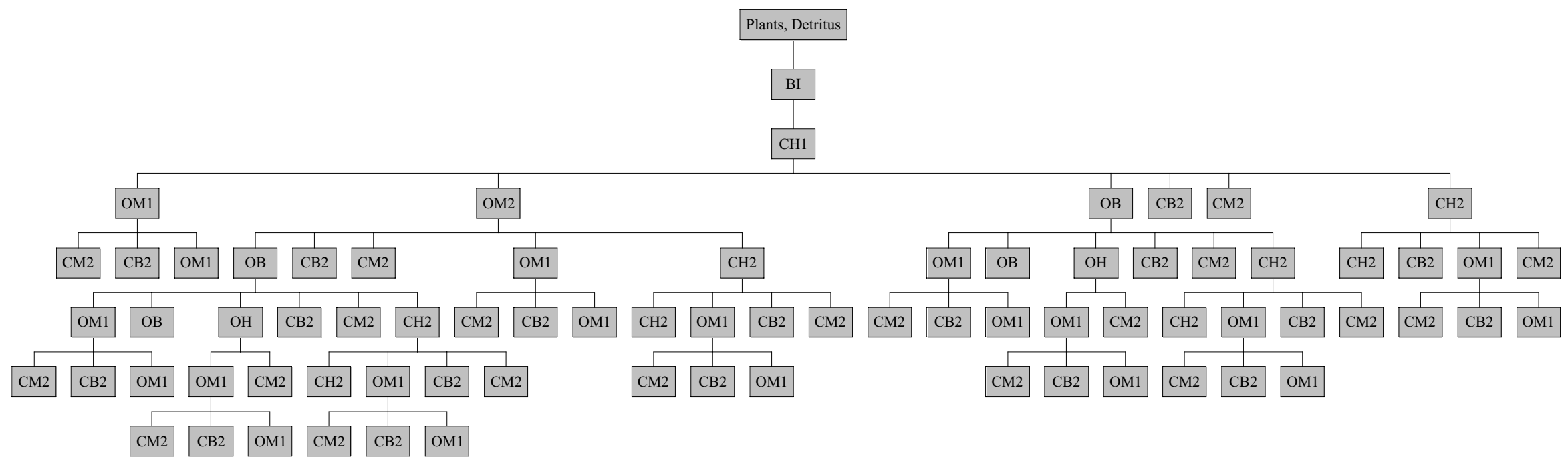




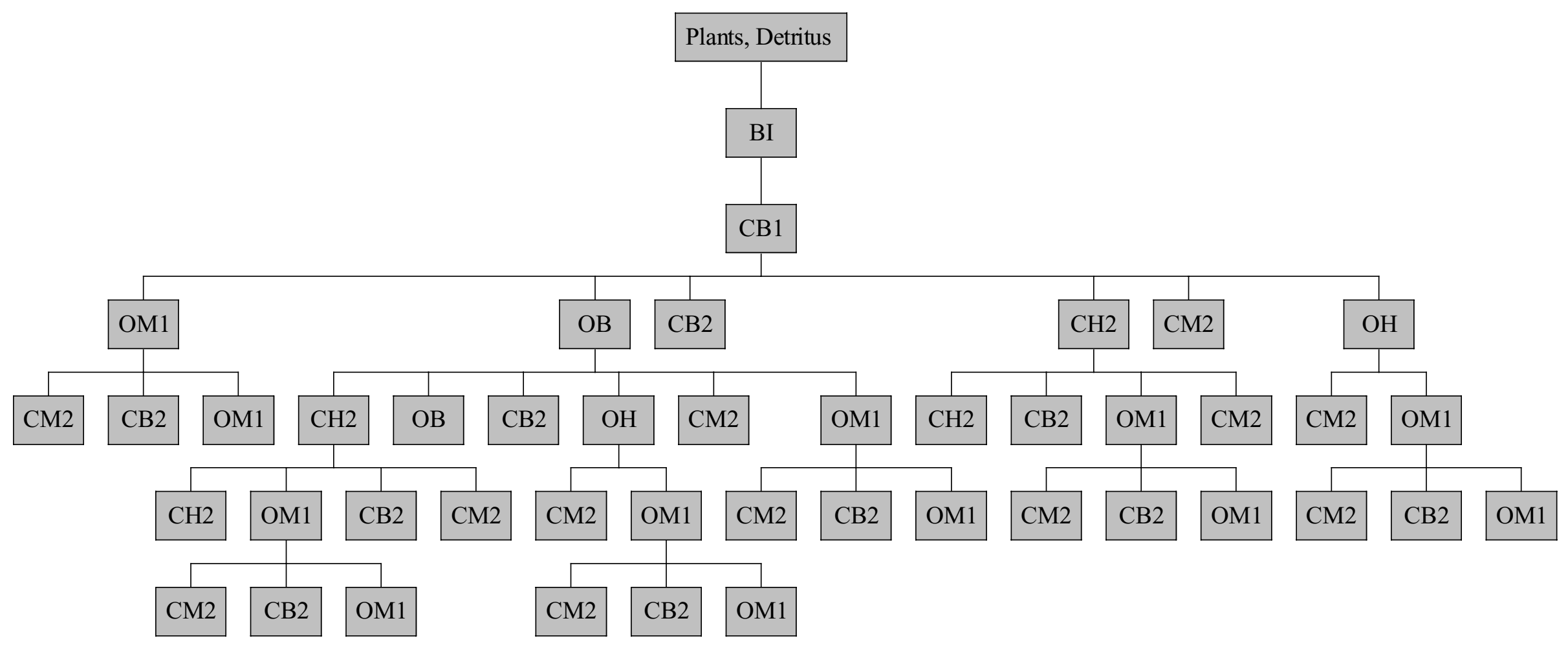


g.

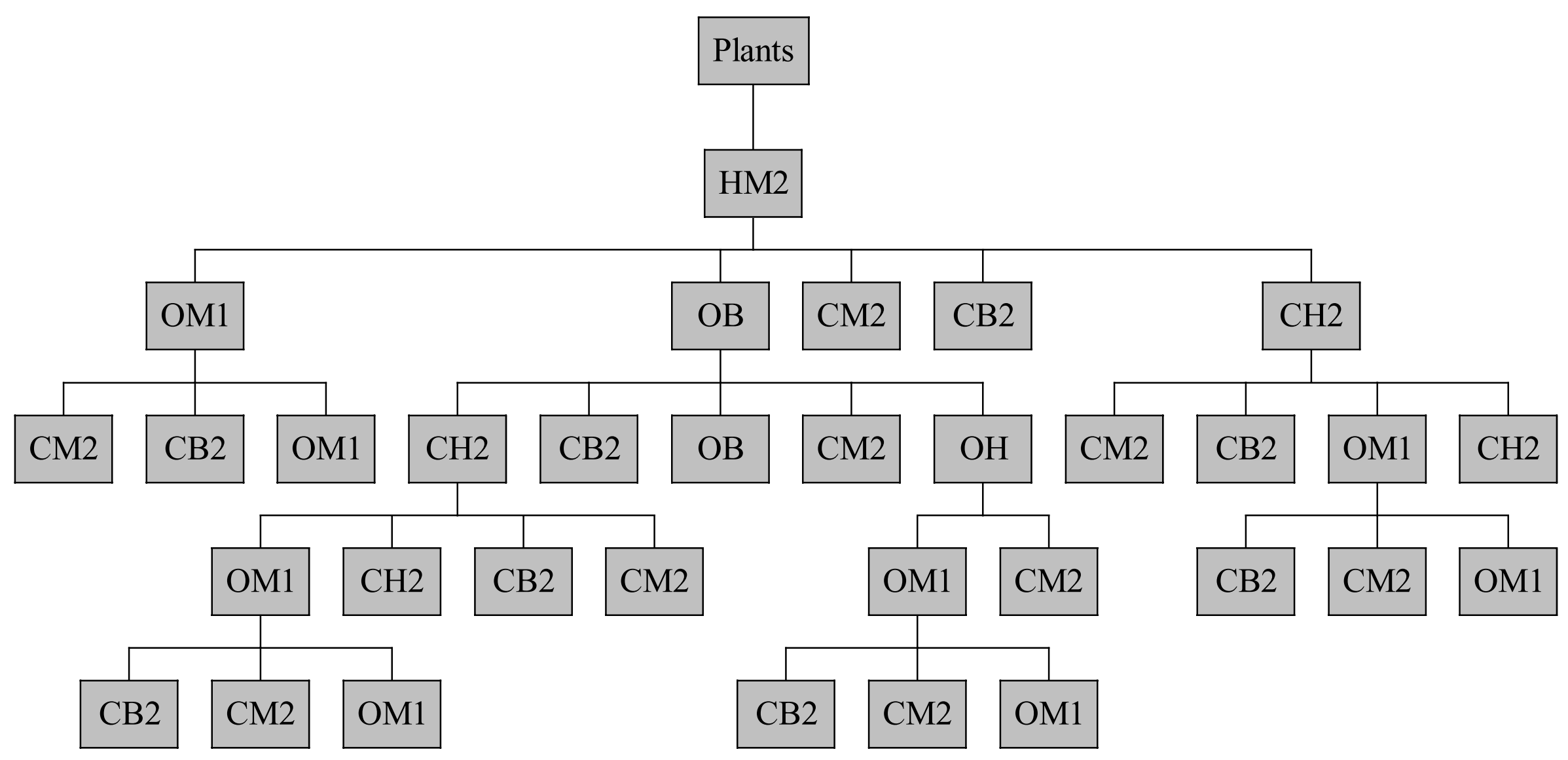


h.

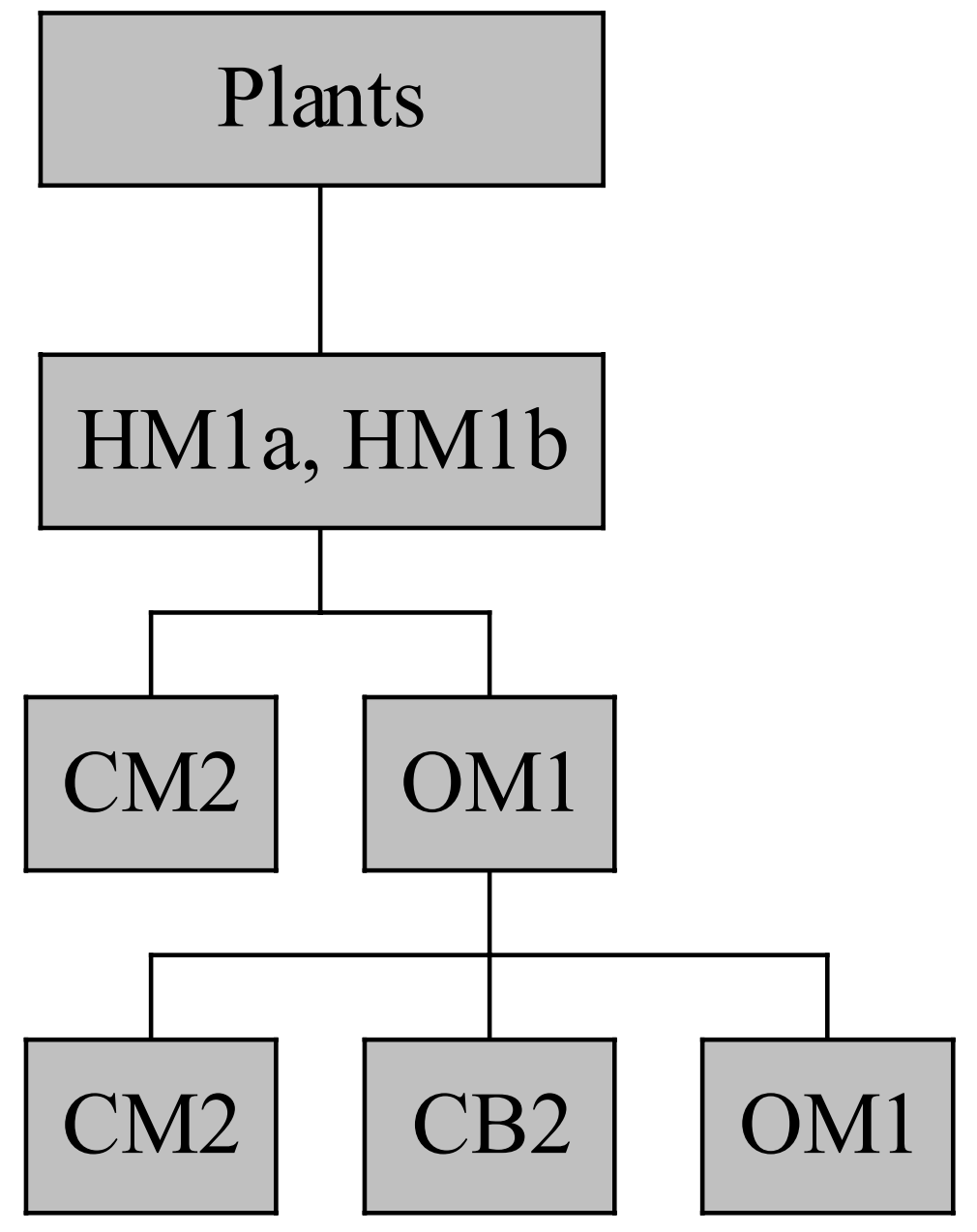

i.

\section{Plants, Detritus}

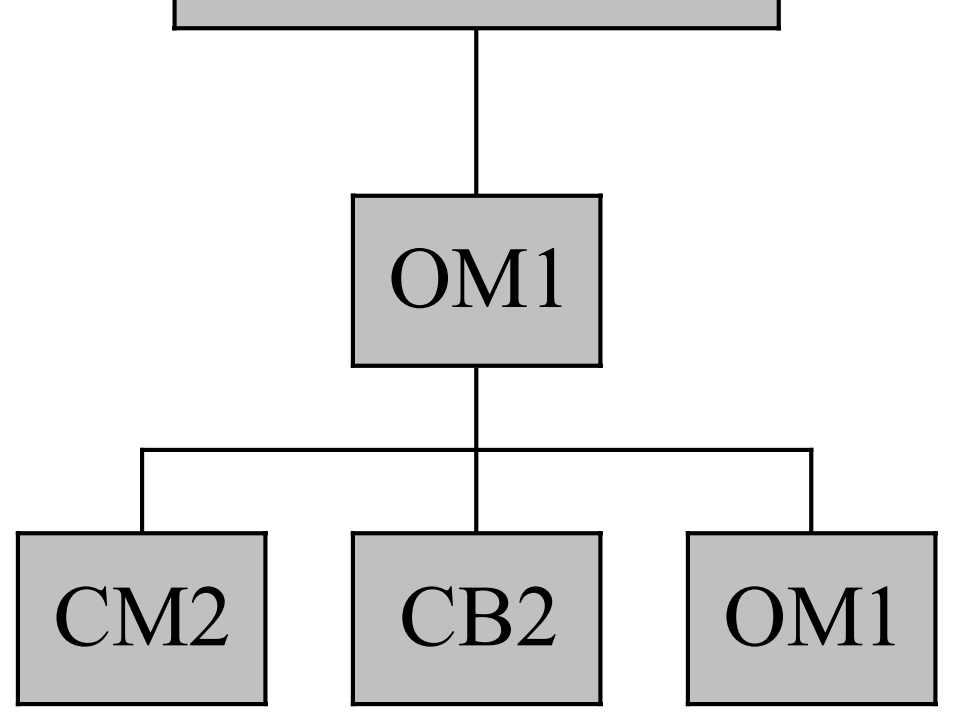


j.

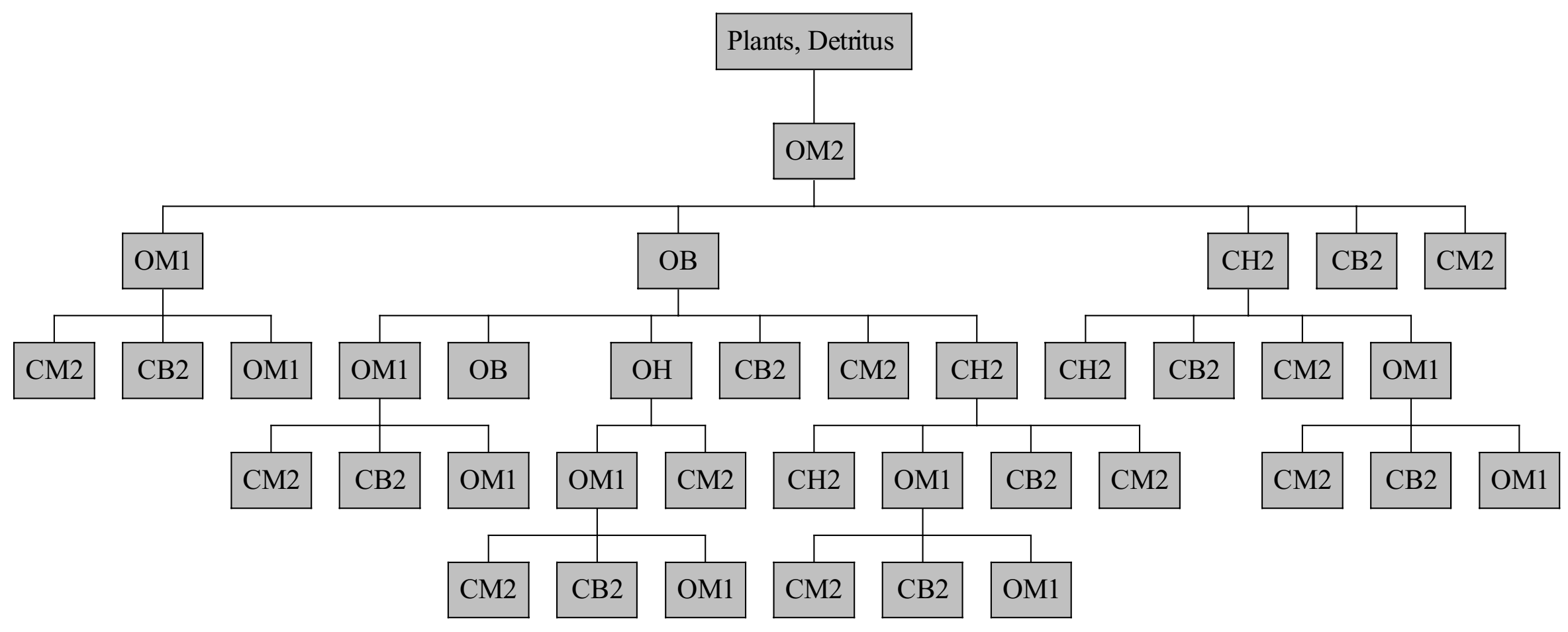


$\mathrm{k}$.

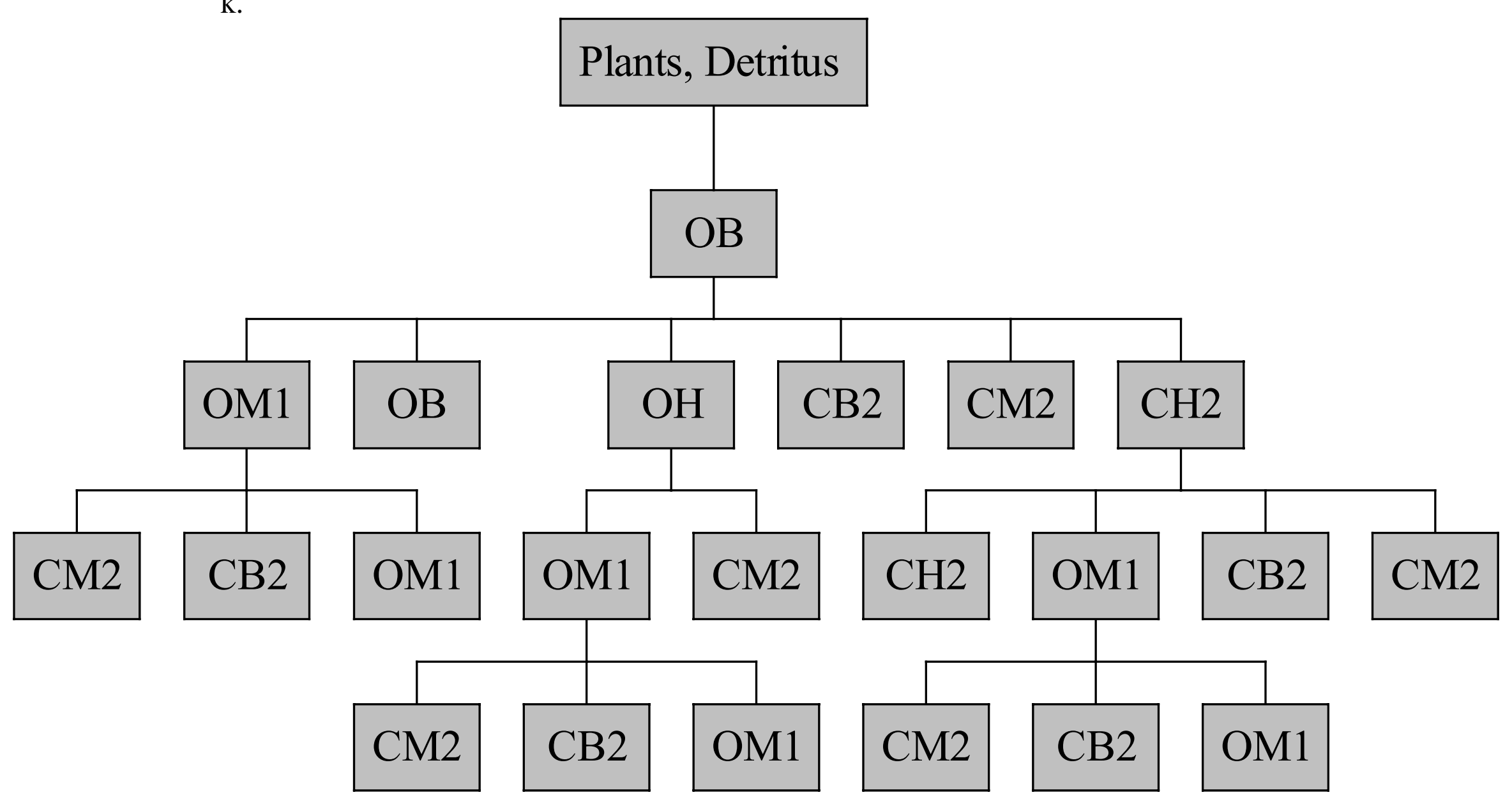


1.

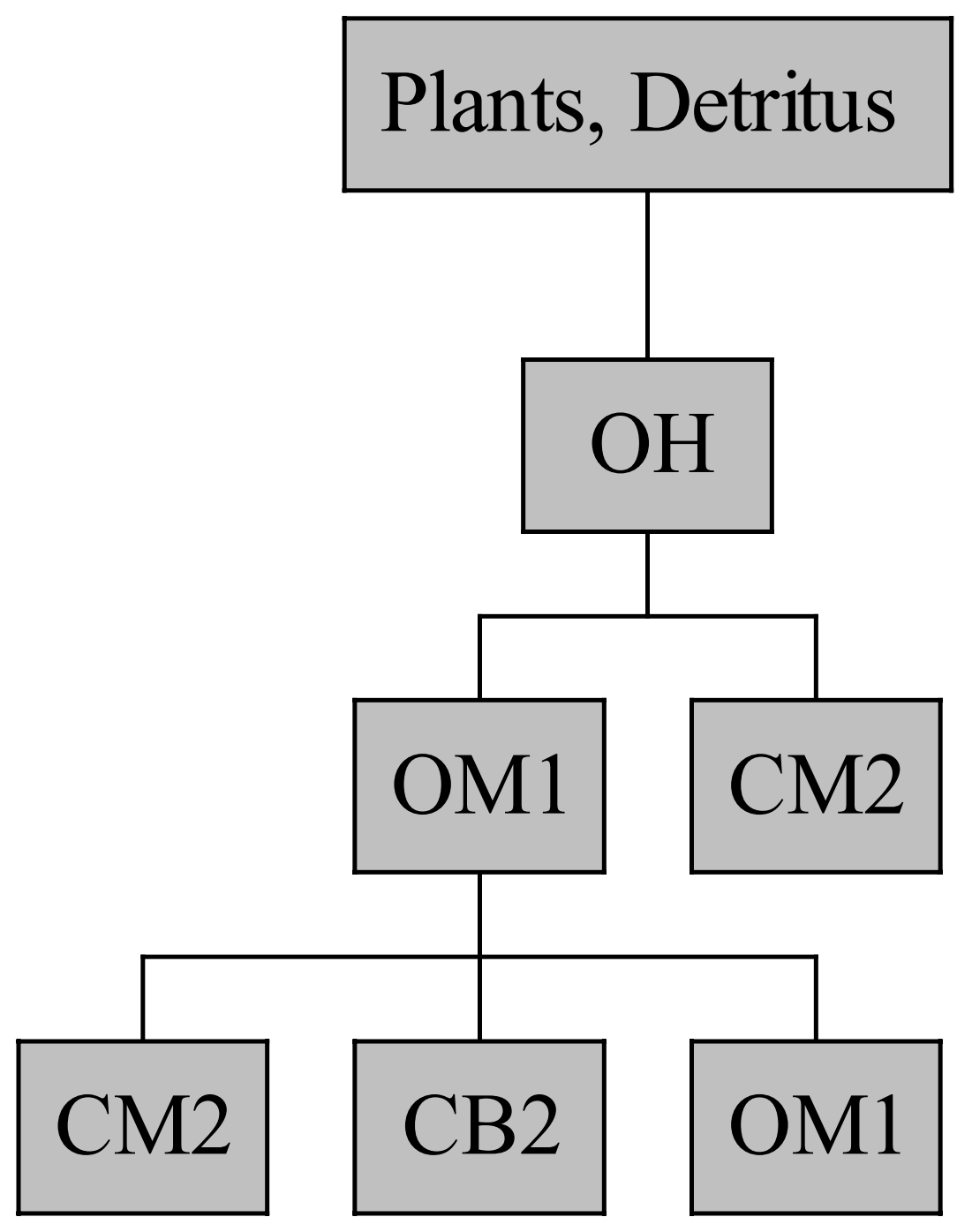

$\mathrm{m}$.

\section{Detritus}

CB2 
n.

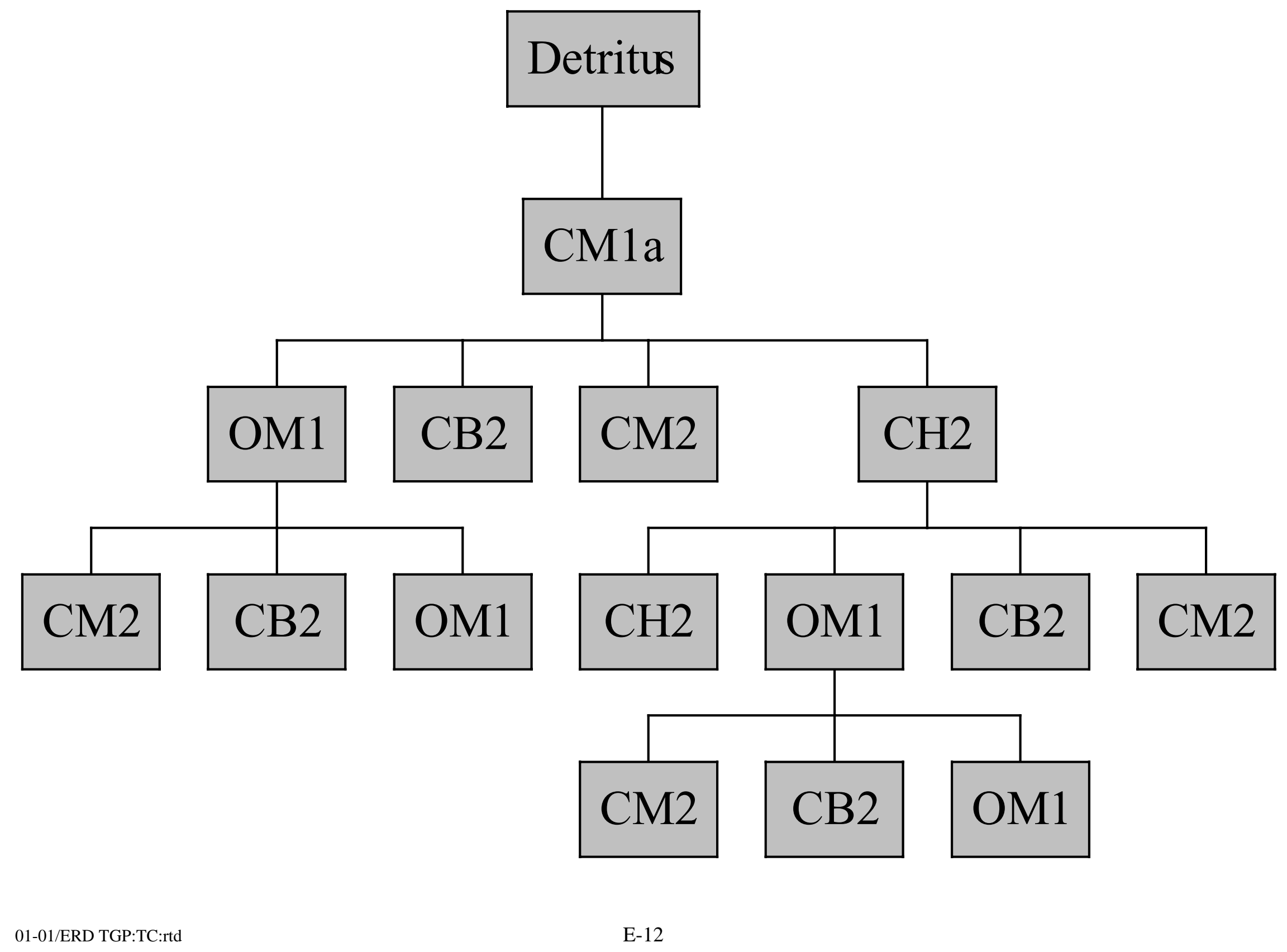




\section{Appendix F \\ Glossary}




\section{Appendix F}

\section{Glossary}

Basal Species:

Entomophage:

Folivore:

Fossorial:

Fundamental Niche:

Granivore:

Herptiles:

Invertivore:

Lagomorph:

Phytophagous:

Realized Niche:
Species at the lowest trophic level; autotrophs, or primary producers.

Insect eater.

An herbivore that feeds on foliage.

Describes species that are adapted to digging or burrowing.

The range of environmental conditions within which a species could potentially be found.

An herbivore that feeds on seeds/grains.

Amphibians and reptiles, collectively.

A species whose diet is restricted to invertebrates.

Member of the order Lagomorpha; commonly refers to rabbits and hares.

Plant-eating.

The range of environmental conditions within which a species is actually found. 